\title{
$2 \operatorname{sen} 2$

\section{To: (Receiving Organization)}

SNE Project - 2 HAOO

5. Proj./Prog./Dept./Div.:

Waste Management Project

8. Originator Remarks:

Sampling and Analysis Plan developed for disposal to ERDF of waste resulting from the $K$ Basins Interim Remedial Action CERCLA ROD (EPA 541-R99-059).
11. Receiver Remarks:
11A. Design Baseline Document? $\square$ Yes $\square$ No

3. From: (Originating Organization)

WMP - 35200

6. Design Authority/Design Agent/Cog. Engr.:

J. I. Westcott

4. Related EDT No.

7. Purchase Order No.:

9. Equip./Component No::

10. System/Bldg./Facility:

12. Major Assm. Dwg. No.:

13. Permit/Permit Application No.:

14. Required Response Date June 14, 2000

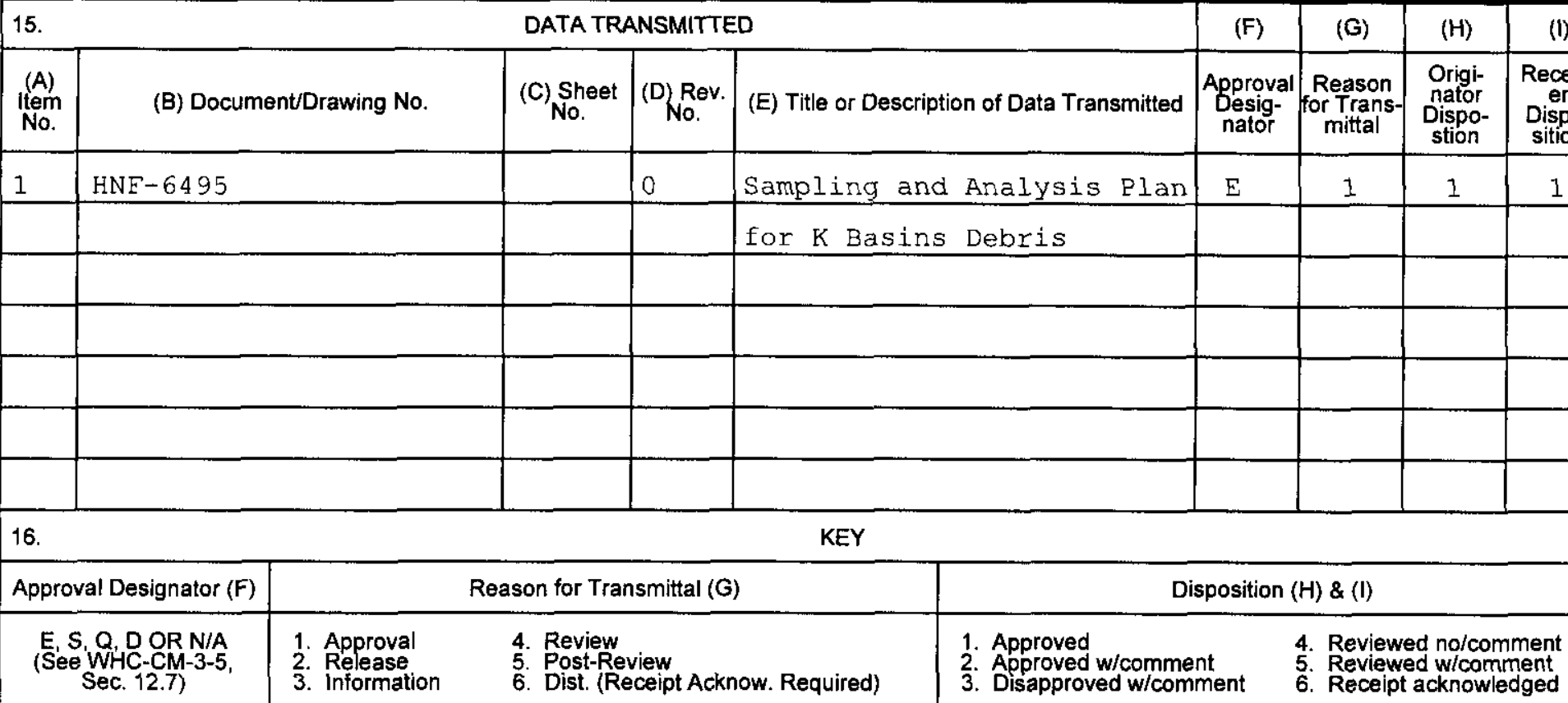
SIGNATURE/DISTRIBUTION

(See Approval Designator for required signatures)

17.

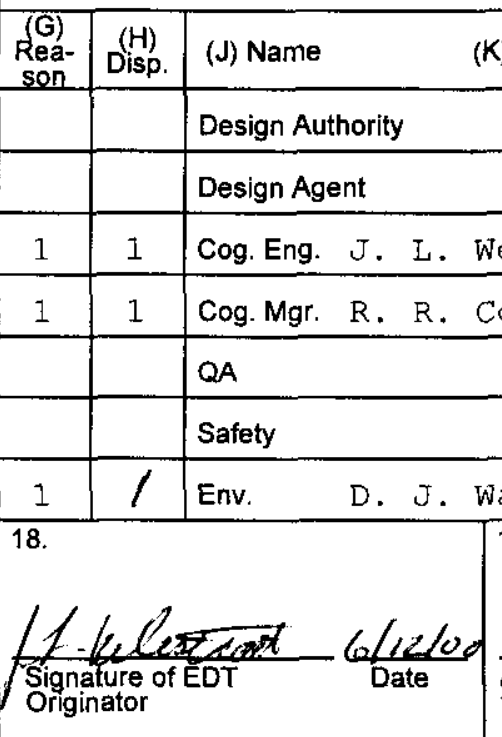

BD-7400-172-2 (10/97)

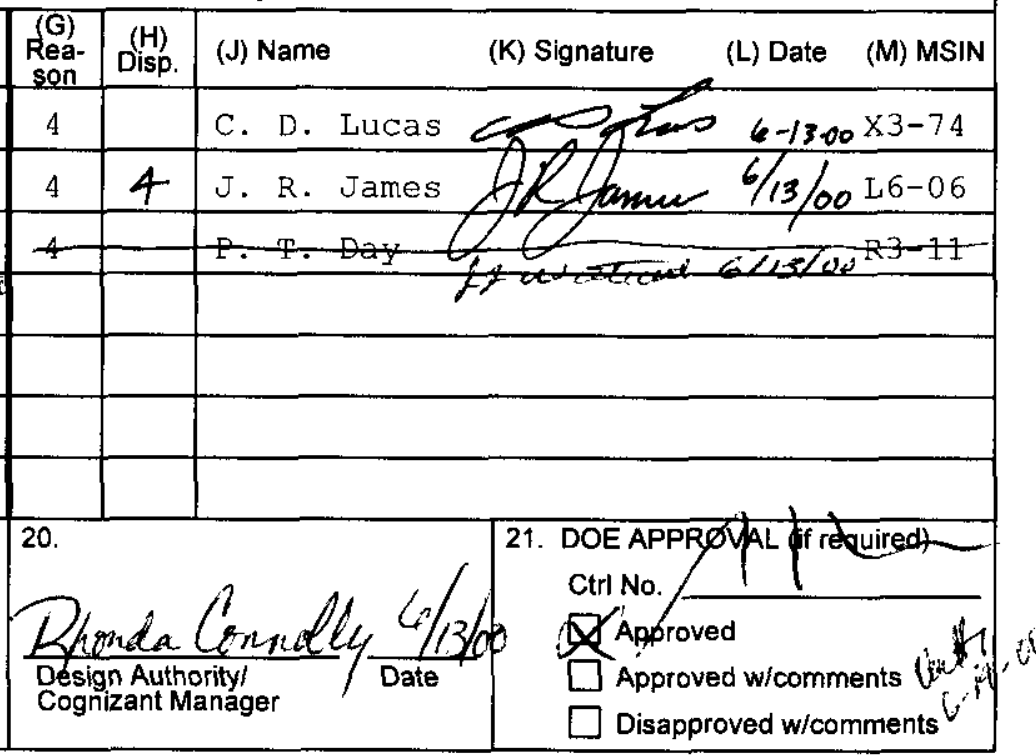

BD-7400-172-1 
HNF-6495

Revision 0

\section{Sampling and Analysis Plan for K Basins Debris}

Prepared for the U.S. Department of Energy

Assistant Secretary for Environmental Management

Project Hanford Management Contractor for the

U.S. Department of Energy under Contract DE-AC06-96RL13200

Fluor Hanford

P.O. Box 1000

Richland, Washington 
HNF-6495

Revision 0

EDT 622851

\section{Sampling and Analysis Plan for K Basins Debris}

Document Type: ENV

Division: WM

J. L. Westcott

Fluor Hanford

Date Published

June 2000

Prepared for the U.S. Department of Energy

Assistant Secretary for Environmental Management

Project Hanford Management Contractor for the

U.S. Department of Energy under Contract DE-AC06-96RL13200

Fluor Hanford

P.O. Box 1000

Richland, Washington
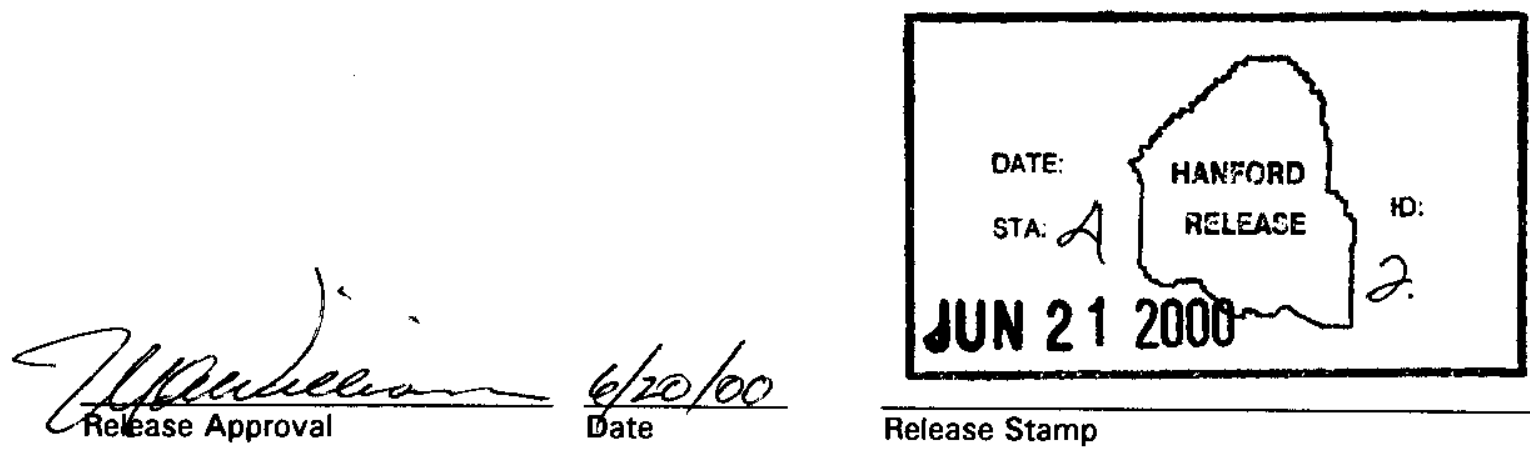

Release Stamp 
TRADEMARK DISCLAIMER

Reference herein to any specific commercial product, process, or service by trade name, trademark, manufacturer, or otherwise, does not necessarily constitute or imply its endorsement, recommendation, or favoring by the United States Government or any agency thereof or its contractors or subcontractors.

This report has been reproduced from the best available copy. Avallable in paper copy and microfiche.

Available electronically at http://Www.doe.gov/bridge. Available for a processing fee to the U.S. Department of Energy and its contractors, in paper, from:

U.S. Department of Energy

Office of Scientific and Technical Information

P.O. Box 62

Oak Ridge, TN 37831-0062

phone: $865-576-8401$

fax: 865-576-5728

email: reports@adonis.osti.gov(423) 576-8401

Available for saie to the public, in paper, from:

U.S. Department of Commerce

National Technical Information Service

5285 Port Royal Road

Springfield, VA 22161

phone: $800-553-6847$

fax: 703-605-6900

email: orderse ntis.fedworld.gov

online ordering: http://www.ntis.gov/ordering.htm

Primed in the United States of America

Total Pages: $\quad 83$ 


\section{EXECUTIVE SUMMARY}

This Sampling and Analysis Plan presents the rationale and strategy for sampling and analysis activities to support removal of debris from the K-East and K-West Basins located in the $100 \mathrm{~K}$ Area at the Hanford Site. This project is focused on characterization to support waste designation for disposal of waste at the Environmental Restoration Disposal Facility (ERDF). This material has previously been dispositioned at the Hanford Low-Level Burial Grounds or Central Waste Complex.

The structures that house the basins are classified as radioactive material areas. Therefore, all materials removed from the buildings are presumed to be radioactively contaminated. Because most of the materials that will be addressed under this plan will be removed from the basins, and because of the cost associated with screening materials for release, it is anticipated that all debris will be managed as low-level waste. Materials will be surveyed, however, to estimate radionuclide content for disposal and to determine that the debris is not contaminated with levels of transuranic radionuclides that would designate the debris as transuranic waste.

Debris that contains Resource Conservation and Recovery Act of 1976 / Washington State dangerous constituents above regulated levels will designate as mixed waste. These constituents may be present at levels that require treatment to comply with Land Disposal Restrictions. Debris composed primarily of pieces $>60 \mathrm{~mm}$ that requires treatment for compliance with the Land Disposal Restrictions will be treated through macro-encapsulation as an approved alternative treatment technology for debris under 40 Code of Federal Regulations 268.45. Treatment via macroencapsulation is generally cheaper than chemical analyses. Debris $\leq 60 \mathrm{~mm}$ will be treated as appropriate, based on Resource Conservation and Recovery Act of 1976 (RCRA) constituents. Only a small amount of debris $\leq 60 \mathrm{~mm}$ is anticipated. 
The sampling design for the debris uses facility or historical radiological sample data to establish the radionuclide/isotopic distribution of radiological constituents of concern. The radionuclide distributions are established for each waste stream and subsequently used to estimate the content of constituents of potential concern, indexed to cesium-137. The cesium-137 content of the waste will be estimated using portable radiation dose-rate meters and gamma detectors. K Basin staff will use the correlation between surveys and individual radionuclide ratios to cesium-137 when evaluating data from radiological dose rate, or gamma surveys to estimate radionuclide inventories for waste shipments.

In cases where assumptions used to establish historical radionuclide ratios are not applicable, contingency sampling and analysis may be required. Section 2.4 presents methods to obtain contingency laboratory analysis of the debris to measure specific isotopes to allow creation of appropriate isotopic ratios for a waste stream. Section 2.4 also includes use of nondestructive analysis as a contingency analytical approach. It must be emphasized that Section 2.4 is for contingency analysis and not routine use.

Analysis of the water from the basins and the outlet of the ion-exchange module will be used to determine the radionuclide content of the modules. Section 2.3 discusses the details of this approach and utilizes existing sampling and analysis procedures.

For painted debris and rags with stripped paint, the waste larger than $60 \mathrm{~mm}$ will be encapsulated, as allowed by the current regulations. No new characterization is presented for this waste as historical data are available for the paint. The concentrations of RCRA constituents in the paint will be based on the entire mass of debris being disposed to assess whether the waste will be designated as RCRA hazardous. Waste smaller than $60 \mathrm{~mm}$ will be managed based on a determination of hazardous constituents. 
This Sampling and Analysis Plan is based on the results of implementing the Data Quality Objectives Process as documented in the Data Quality Objectives Process for Designation of $K$ Basin Debris (HNF 2000a). The following topics are summarized in Section 1.0:

- historical data,

- rationale for data collection, including surveys and sampling, and

- results of the Data Quality Objectives Process.

Section 2.0 includes the quality assurance project plan that includes details of the survey, analytical methods, detection limits, accuracy and precision criteria.

Section 3.0 includes the field sampling plan that summarizes information needed by those collecting and shipping samples to the laboratory or those performing the surveys. 


\section{TABLE OF CONTENTS}

1.0 INTRODUCTION

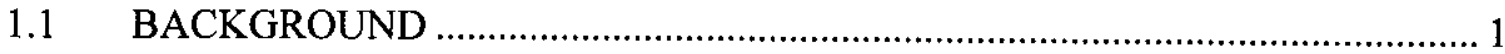

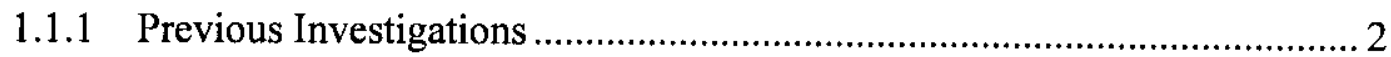

1.1.2 Contaminants of Potential Concern .......................................................... 4

1.2 DATA QUALITY OBJECTIVES ............................................................. 5

1.2.1 Step 1: Statement of the Problem............................................................. 10

1.2.2 Step 2: Identify the Decisions ........................................................... 10

1.2.3 Step 3: Identify Inputs to the Decisions .................................................. 10

1.2.4 Step 4: Define the Study Boundaries ........................................................ 11

1.2.5 Step 5: Decision Rules ........................................................................ 14

1.2.6 Step 6: Limits on Decision Error .............................................................. 15

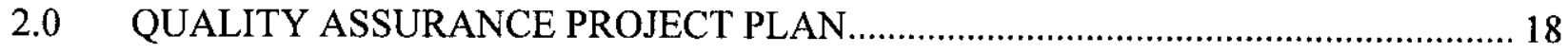



2.1.1 Project and Task Organization .................................................................. 18

2.1.2 Roles and Responsibilities .................................................................. 18

2.1.3 Special Training Requirements/Certification .......................................... 20

2.1.4 Quality Objectives and Criteria for Measurement Data .......................... 21

2.1.5 Documentation and Records ................................................................ 23

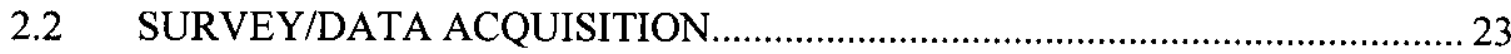

2.2.1 Dose Rate to Curie Conversion............................................................... 24

2.2.2 Cesium-137 Curie to Radionuclide Content Estimate for Above- and Below- Water Waste ............................................................................ 25

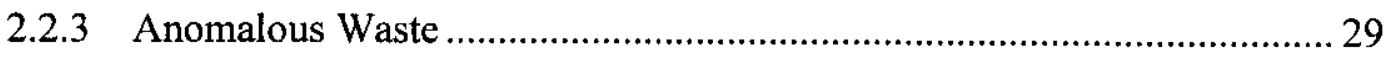

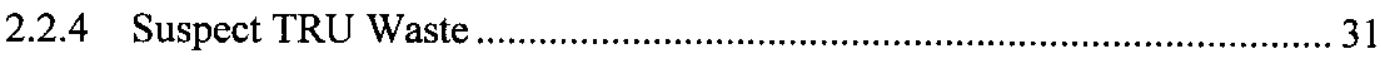


2.2.5 Ion-Exchange Modules (Waste Stream 15, HNF 2000a) …………......... 32

2.2.6 Radiological Survey Methods/Quality Control Requirements ..................32

2.2.7 Waste Handling and Custody Requirements ……………….....................34

2.2.8 Waste and Sample Shipping ................................................................... 34

2.3 K BASIN WATER SAMPLING FOR IXM WASTE DESIGNATION ..............34

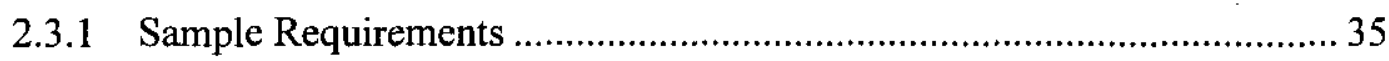

2.3.2 Water Sample Handling and Custody Requirements................................ 35

2.3.3 Water Sample Preservation, Containers and Holding Times..................... 35

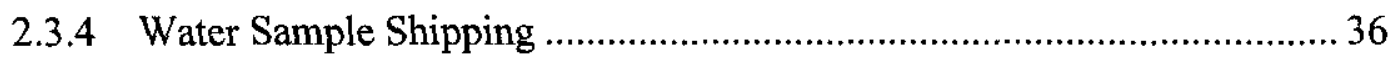

2.3.5 Analytical Methods Requirements for Water Samples..............................36

2.3.6 Laboratory Quality Control Requirements for Water Samples ................ 37

2.3.7 Instrument/Equipment Testing, Inspection, and Maintenance ……......... 38

2.3.8 Instrument Calibration and Frequency..................................................... 38

2.3.9 Inspection/Acceptance Requirements for Supplies and Consumables ..... 39

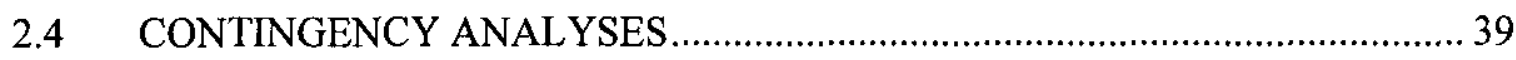

2.4.1 When Contingency Analyses/Nondestructive Assay will be Required .... 39

2.4.2 Contingency Sample Locations, Handling and Custody Requirements ... 40

2.4.3 Contingency Sample Preservation, Containers, Size, and Holding Times40

2.4.4 Contingency Sample Shipping............................................................. 41

2.4.5 Analytical Methods Requirements for Contingency Samples................... 41

2.4.6 Quality Control Requirements for Contingency Samples ........................ 41

2.4.7 Instrument/Equipment Testing, Inspection, and Maintenance ................. 43

2.4.8 Instrument Calibration and Frequency..................................................... 43

2.4.9 Inspection/Acceptance Requirements for Supplies and Consumables ..... 43 
2.4.10 Nondestructive Assay

2.5 ASSESSMENT/OVERSIGHT FOR SURVEY SAMPLING AND ANALYSIS 44

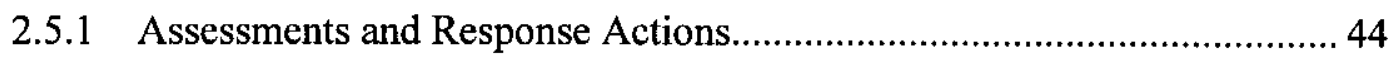

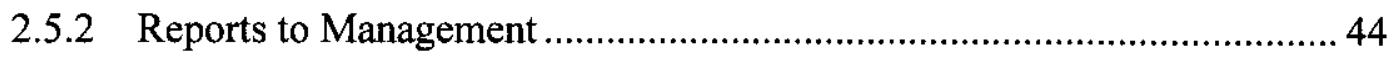

2.6 DATA REVIEW, VALIDATION AND USABILITY ….................................... 44

2.6.1 Data Review and Verification Requirements .......................................... 44

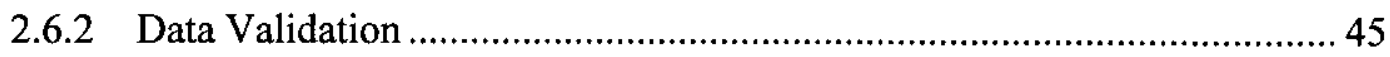

2.6.3 Reconciliation With User Requirements ...............................................45

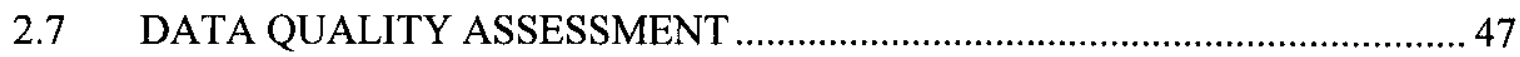

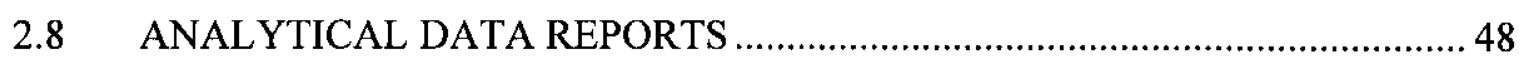

3.0 FIELD RADIOLOGICAL SURVEY AND SAMPLING OBJECTIVES .......................49

3.1 RADIOLOGICAL SURVEY OBJECTIVES................................................. 49

3.2 SURVEY LOCATIONS AND FREQUENCY …………................................ 49

3.3 RADIOLOGICAL SURVEY QUALITY CONTROL .......................................50

3.4 RADIOLOGICAL SAMPLING OBJECTIVES AND REQUIREMENTS ......... 50

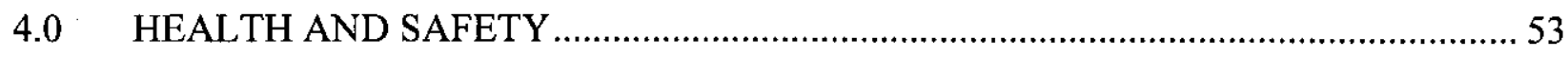

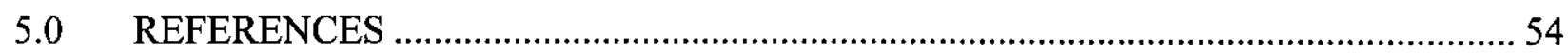

$5.1 \quad$ SPENT NUCLEAR FUELS PROCEDURES ……….....................................56

5.2 PROJECT HANFORD MANAGEMENT SYSTEM PROCEDURES ………...... 57

5.3 WASTE MANAGEMENT LABORATORY ANALYTICAL PROCEDURES. 58 APPENDIX A A-1 APPENDIX B B-1 


\section{FIGURES}

Figure 1-1. K Basin Debris Disposition Decision Logic ......................................................12

Figure 1-2. Chemical Waste Designation Decision Logic............................................................13

Figure 2-1. Sampling/Analysis and Waste Management Organization Chart.............................19

\section{TABLES}

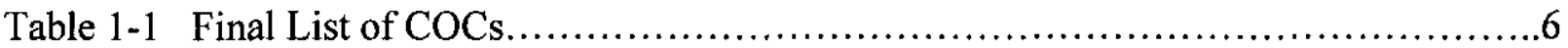

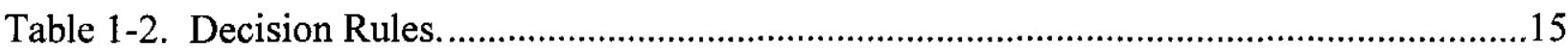

Table 1-3. Summary of Sampling Frequencies and Locations. ................................................... 17

Table 2-1. Target Accuracy and Precision of Laboratory Methods for Water and Contingency Sampling. 1

Table 2-2. Radiological Dose to Curie Conversion, Estimated Detection Limits, Waste

Container Applicability. (2 Pages)..............................................................................27

Table 2-3. COC Radionuclide Ratios to Cesium-137 for Characterization of K Basin Waste. ..30

Table 2-4. Designated Ratios and Definition of Anomalous Waste.

Table 2-5. Water Sample Measurement Methods, Detection Limits, and Minimum

Sample Volumes for Selected Radionuclide COCs. (2 pages).

Table 2-6. Contingency Sample Measurement Methods, Detection Limits, and Sample

Volumes for Selected Radionuclide COCs.

Table 3-1. Radiological Survey Instrumentation QC Requirements. (2 Pages) 


\section{ACRONYMS}

ACM asbestos-containing material

AJHA

ALARA

CERCLA automated job hazards analysis

as low as reasonably achievable

Comprehensive Environmental Response, Compensation, and Liability Act of

1980

CFR Code of Federal Regulations

CMP

$\mathrm{COC}$

CWC

DOE

DQO

EHW

EPA

ERDF

FH

GEA

GM

HASP

HASQARD

HGET

HIC

HM/HW

HSRCM

ICP

IWTS

IX

IXM

KE

KW

LDR

LLBG

LLW

MDL

MS

$\mathrm{NaI}$

NDA

NRCW

PCB

PHMC

QA

QC

RCRA
Chemical Management Program

contaminant of concern

Central Waste Complex

U.S. Department of Energy

data quality objective

extremely hazardous waste

U.S. Environmental Protection Agency

Environmental Restoration Disposal Facility

Fluor Hanford, Inc.

gamma energy analysis

Geiger-Mueller

Health and Safety Plan

Hanford Analytical Quality Assurance Requirements Documents

Hanford General Employee Training

high integrity container

hazardous material/hazardous waste

Hanford Site Radiological Control Manual

inductively coupled plasma

Integrated Water Treatment System

ion exchange

ion-exchange module

$\mathrm{K}$ East

K West

Land Disposal Restrictions

low-level burial ground

low-level waste

minimum detection limit

mass spectroscopy

sodium iodide

nondestructive assay

nonrestricted contaminated waste

polychlorinated biphenyl

Project Hanford Management Contract

quality assurance

quality control

Resource Conservation and Recovery Act of 1976 
RCW restricted contaminated waste

RMA radioactive material area

ROD Record of Decision

RPD relative percent difference

SAP Sampling and Analysis Plan

SNF spent nuclear fuel

SOP standard operating procedure

TBD to be determined

TC toxicity characteristic

TCLP Toxicity Characteristic Leachate Procedure

TRU transuranic

TSCA Toxic Substances Control Act of 1976

WAC waste acceptance criteria

WSCF Waste Sampling and Characterization Facility 


\subsection{INTRODUCTION}

The U.S. Department of Energy (DOE) has developed a schedule and approach for removal of spent fuels, sludge, and debris from the $\mathrm{K}$ East $(\mathrm{KE})$ and $\mathrm{K}$ West $(\mathrm{KW})$ Basins, located in the $100 \mathrm{~K}$ Area at the Hanford Site. This Sampling and Analysis Plan (SAP) is focused on removal of debris from the Basins and onsite disposal of debris at the Environmental Restoration Disposal Facility (ERDF). The document identifies the waste streams, as well as field survey and sampling approaches to be used to characterize the debris. This material previously has been dispositioned at the Hanford Low-Level Burial Grounds (LLBGs) or Central Waste Complex (CWC). The Comprehensive Environmental Response, Compensation, and Liability Act of 1980 (CERCLA) Record of Decision (ROD) (Declaration of the Record of Decision for DOE Hanford 100 Area [EPA et al. 1999]) for this material indicates this waste may to be disposed of at the ERDF if it meets that facility's waste acceptance criteria (WAC).

\subsection{BACKGROUND}

The KE and KW Reactors and their associated fuel storage basins were constructed in the early 1950s. The basins are located in the Hanford 100K Area within $420 \mathrm{~m}(1,380 \mathrm{ft})$ of the Columbia River. The fuel basins are large, open-topped concrete pools, each containing approximately 4.9 million liters (1.3 million gallons) of demineralized water. The basins were originally used to store spent nuclear fuel (SNF) from the KE and KW Reactors until the early $1970 \mathrm{~s}$, when these reactors were removed from service and the fuel removed from the basins. The Basins subsequently have been used to store SNF from the Hanford N Reactor. The KE and KW fuel basins currently hold approximately 1,200 metric tons and 900 metric tons of N Reactor $\mathrm{SNF}$, respectively. The spent fuel elements are contained in canisters placed in storage racks under $5 \mathrm{~m}(16 \mathrm{ft})$ of water for cooling and radiation shielding.

The CERCLA ROD (EPA et al. 1999) for the K Basin defines debris qualitatively as all solid waste generated from the removal of materials from the KE and KW Basins, excluding SNF, sludge, and water. The project working definition of debris, as used in both the ROD and the Focused Feasibility Study for the K Basins Interim Remedial Action (DOE/RL 1999) is not to be confused with the Resource Conservation and Recovery Act of 1976 (RCRA) definition of debris provided in 40 Code of Federal Regulations (CFR) 268.2 (g). For purposes of establishing disposal requirements, RCRA defines debris as a solid material exceeding a $60 \mathrm{~mm}(2.34 \mathrm{in}$.) particle size. Thus, waste from the $\mathrm{K}$ Basins is subdivided into two categories, small particles (60 $\mathrm{mm}$ or less) that are subject to standard RCRA waste disposal requirements, and large debris (greater than $60 \mathrm{~mm}$ ) that is eligible for disposal under the RCRA debris requirements. All project debris will be managed as required by the RCRA Land Disposal Restrictions (LDR). 
The project does not anticipate that a significant quantity of the smaller material $(<60 \mathrm{~mm})$ will be generated. These items will generally be byproducts from larger debris items and will be managed with the related waste stream(s). Equipment that is not an integral part of the basin structures will be decontaminated as appropriate, removed from the basin, drained, packaged, and disposed of as debris.

Project debris includes items located both above and below the water in the basins, wastes generated from operation of the water and sludge treatment systems, and wastes generated during basin deactivation. Pressure washing and rinsing of debris will be used to remove the majority of sludge from the surface of debris removed from the basins. This approach will eliminate the majority of surface contamination associated with radionuclides, as well as polychlorinated biphenyls (PCBs), and regulated metals associated with the sludge.

The Integrated Water Treatment System (IWTS) equipment and the structure in which it is installed will be removed, decontaminated as appropriate, packaged, and disposed as debris. Characterization of the IWTS, however, is not included in the sampling scheme discussed in this SAP. Debris also includes aluminum and stainless steel fuel canisters in the basins, fuel racks, and miscellaneous piping, tools, hose, scrap, and other materials. There are approximately 1,800 empty and 7,400 full canisters in the two basins with an estimated waste volume of $27,600 \mathrm{ft}^{3}$. Full canisters will be managed for disposal only after the fuel has been removed.

Debris management will depend on the waste designation. Because the $\mathrm{K}$ Basin structures are designated as a radioactive material area (RMA), all materials are anticipated to be low-level waste (LLW), unless they can be released through survey and analysis or contamination is detected that causes the material to be designated transuranic (TRU) waste. Debris might designate as LLW, mixed waste, TRU waste, or TRU mixed waste, depending on contaminant concentrations associated with specific items.

\subsubsection{Previous Investigations}

$\mathrm{K}$ Basin personnel have grouped debris into discrete waste streams for this project. Summaries of the historical data for these waste streams are provided below:

Mixed Waste Debris. No waste-specific radiochemical laboratory analyses have been performed to date on this waste stream. An estimate of the cesium-137 content of the waste was performed for past shipments using established dose-to-curie relationships (WHC 1996a, WHC 1996b). Radionuclides considered reportable in previous waste shipments included strontium-90, cesium-137, plutonium-239/240, americium-241, and plutonium-241. This entire waste stream was designated as low-level radioactive mixed waste. 
Inductively coupled plasma (ICP) total metals analysis (SW-846 Method 6010A [Test Methods for Evaluating Solid, Waste Physical/Chemical Methods, EPA 1997]) have been performed on nine paint chip samples, as well as multiple chip samples from the overhead crane. Toxic metals (silver, arsenic, barium, cadmium, chromium, lead, and selenium) were confirmed to be present in paint chips at total concentrations greater than screening limits for the toxicity characteristic (TC) criteria.

Above-Water Waste. Radiochemical analyses for gross alpha, gross beta, cobalt-60, cesium-137, and americium-241 were performed on twenty $105-\mathrm{KE}$ smears. Nondestructive assay (NDA) analysis of 20 compacted drums and NDA of four boxes of waste was performed. Radionuclides in the resulting waste profiles included strontium-90, cesium-137, europium-152, plutonium-238, plutonium-239, plutonium-240, americium-241, plutonium-241, and curium-244. This waste stream was designated as low-level radioactive waste with the exception of one barrel, which was estimated to potentially contain TRU waste. Nonradiological sampling was limited to the same paint chip samples used for characterizing the mixed waste debris. Some of this abovewater debris also could be designated mixed waste.

Underwater Debris. Radiochemical analyses were performed on coupons from pipes that were rinsed and removed from the basin. Analyses included total alpha, gamma energy analysis (GEA), strontium-89/90, americum-241, and total uranium. Radionuclides that were found above detection limits included cesium-137, cobalt-60, europium-154/155, strontium-90, uranium, plutonium-238, 239/240, and americium-241. In addition, NDA was used to evaluate 11 boxes of rinsed debris on the $100 \mathrm{~K}$ Rad Pad for maximum cesium- 137 content. All of the waste was determined to be low-level radioactive waste.

Polychlorinated biphenyl analysis was conducted on waters from the KE and KW Basins; PCBs were not detected using a minimum detection limit (MDL) of $0.5 \mathrm{ug} / \mathrm{ml}$. Inductively coupled plasma analysis for total metals was performed on water samples from both basins and on sludge from the KE Basin only. Although zinc, silicon, copper, and boron were detected in water samples, no TC metals were found above the TC levels, so the water is not a characteristic waste. Metals have been found in KE Basin sludge at concentrations that exceed the total concentration screening level. No Toxicity Characteristic Leachate Procedure (TCLP) analyses were performed on the sludge. Some of the above water debris also could be mixed waste.

Canisters. In 1996, several empty fuel canisters were pressure washed and removed from the basin for characterization (Characterization of Empty Fuel Canisters in $105 \mathrm{KE}$ Basin [WHC 1996c]). Smears were obtained from the canisters and submitted for GEA. The pressurewashed canisters were analyzed by NDA (gamma and neutron analysis) and an estimate was derived for the radionuclide content of the canisters. The NDA results indicated that the rinsed canisters were contaminated with cesium-137, cobalt-60, amercium-241, europium-154, 155, and antimony-125 (WHC 1996d).

Although the report concluded that the pressure washed canisters were not TRU waste, the NDA results did not report any data above the MDL for americium-241 or plutonium-239/240. Subsequent laboratory analysis of smears taken from nine of 11 canisters that were subjected to 
NDA demonstrated a significant americium-241 content (up to $41 \%$ of the measured cesium-137 activity). These smears were analyzed in the laboratory, but were only subjected to gamma analysis and, thus, did not detect any plutonium isotopes. The lack of apparent plutonium-239/240 detected by NDA was explained in the report by a hypothesis that the americium-241 reacted with the underlying canister metal, while the plutonium isotopes were associated more with the sludge that was presumed to be washed off. No data were presented to substantiate that hypothesis.

Asbestos and Asbestos-containing material (ACM). No radiochemical or chemical analyses have been performed.

Ion-exchange Modules. The radionuclide content of the ion-exchange modules (IXMs) was estimated from analysis of basin water and an assumption that $100 \%$ of the radionuclides, except tritium, measured in the water are removed by the IXM. Toxic metals were undetected in $\mathrm{K}$ Basin water (MDLs were less than TC levels); only zinc, silicon, copper, and boron were detected. The potential content of PCBs and toxic metals that may sorb onto the ion exchange (IX) resins was conservatively estimated based on the contaminants of concern (COCs) being present in basin water at reported detection limits. These calculations used the mass of the entire IXM to estimate potential concentrations and assumed that $100 \%$ of the metals and PCBs were sorbed to the exchange resin. The results showed that PCB and metal concentrations (arsenic, lead, and selenium) exceed TC and Toxic Substances Control Act of 1976 (TSCA) screening levels. Calculations were provided in Appendix C of the Data Quality Objective (DQO) Process Document (HNF 2000a) and assume metals concentrations are at the detection limit for the analysis. These calculations (based on the laboratory analytical detection limits) indicate that, based on this conservative approach, the IXM could be designated as hazardous waste and would be subject to treatment to meet LDR.

\subsubsection{Contaminants of Potential Concern}

Polychlorinated biphenyl concentrations in paint are assumed to be below levels of concern for disposal at ERDF (concentrations are based on the total mass for the item, not merely the paint itself). Some items, such as fluorescent light ballasts, are assumed to have regulated PCBs and will be managed appropriately.

The SNF Project will estimate a TC COC to mass ratio for painted objects separately from this SAP. Painted debris, in general, will be assumed to not designate for metals, based on the total mass of the object(s). Based on the concentrations of TC metals that would be required to cause an object to designate as dangerous, the project believes that this is a more efficient approach than sampling the painted debris for characterization. The same approach may be used for other small-volume suspect waste streams, such as light bulbs.

The Listed Waste History at Hanford Facility TSD Units (WHC 1996e) will be reviewed as specific waste streams are generated to verify that there are no listed waste concerns before designation. 
Previous studies indicated that sludge is present in significant volumes in the KE Basin, resulting in potentially higher surface contamination concerns for debris from that location, due to contact with the sludge. Limited analysis of samples from the basins indicates the presence of PCBs in sludge from some locations. All debris will be pressure-washed and drained of free-flowing liquid as it is removed from the basins; after washing, the debris will not subsequently be regulated under the Toxic Substances Control Act of 1976 (TSCA), as approved in the CERCLA ROD (EPA et al. 1999). Debris that has been rinsed/washed must be visually inspected and field screened for radionuclides to confirm the effectiveness of this procedure for each piece.

The DQO Process prepared for debris presented the rationale for exclusion of constituents of potential concern (HNF 2000a). Table 1-1 provides the final list of COCs for each waste stream with the rational for inclusion. The logic for selection of the radioisotopes is presented in the $\mathrm{DQO}$ Process report. Any changes to the list of $\mathrm{COCs}$ and the rationale for these changes are included in the project files through the comment/ response process.

Lower detection limits achieved for basin waster samples collected in a one-time sampling event (May 2000) demonstrated that, for the RCRA metal constituents, the IXMs would not designate as hazardous waste. Analyses for PCBs were not conducted and, thus, the IXMs will be designated as TSCA waste. Ion-exchange modules will be drained of free-flowing liquids and managed as debris in accordance with the ROD (EPA et al. 1999) definition of debris. The U.S. Environmental Protection Agency (EPA) has indicated that the unit includes the IX column and concrete shell and constitutes a high integrity container (HIC), which is equivalent to encapsulation (see HNF 2000a, Appendix B). The project will proceed on this interpretation and the designation of the waste.

\subsection{DATA QUALITY OBJECTIVES}

Fluor Hanford (FH)/Waste Management conducted a DQO Process to support the development of this SAP and determine the appropriate approach for characterizing the debris for disposal.

The scope of the DQO (HNF 2000a) included only characterization of debris from the K Basins and immediately adjacent areas, to allow the SNF Project to assign appropriate waste designation. The scope included characterization for disposal of IXMs servicing the basin water, but not the sand filter and IXMs servicing fuel removal operations. The DQO did not consider the IXMs that are a part of the IWTS. The DQO Process was conducted to provide the strategy for characterizing and designating $\mathrm{K}$ Basin debris to determine if it meets the Environmental Restoration Disposal Facility Waste Acceptance Criteria, Revision 3 (BHI 1998).

As noted above, decisions that were documented through the DQO Process have, in some cases, been modified due to subsequent changes in project direction or based on discussions documented through the comment/response process. These changes are documented in project files and are noted, as appropriate in summaries of the DQO Process provided below. For additional details, the reader should refer to the DQO (HNF 2000a). 
Table 1-1. Final List of COCs. (5 Pages)

\begin{tabular}{|c|c|c|c|}
\hline WS\# & $\begin{array}{c}\text { Material (Component)/ } \\
\text { Category }\end{array}$ & $\mathrm{COC}$ & Rationale for Inclusion \\
\hline 1 & Painted Debris & $\begin{array}{l}\text { radioactive COC list' } \\
\text { TC metals -As, Ba, Cd, Cr, Pb, } \\
\text { Hg, Sc, } \mathrm{Ag} \\
\text { 2-(2-methoxy)-Ethanol, 2- } \\
\text { Phthalocyanito-copper (copper } \\
\text { phthalocyanine), 2,2,4- } \\
\text { Trimethyl-I,3- } \\
\text { pentanediolmonoisobutyrate, } 2 \text { - } \\
\text { propoxyethanol, Dibutyl } \\
\text { Phthalate, Naphthalene, } \\
\text { Hydroxypropylmethylcellulose, }\end{array}$ & $\begin{array}{l}\text { Radioactive COC list' } \\
\text { Metals confirmed to be present in } \\
\text { paint at concentrations above } \\
\text { screening limits for TC. } \\
\text { Nonvolatile paint constituents. } \\
\text { Toxicity must be evaluated to } \\
\text { delermine the contribution to } \\
\text { Dangerous Waste Criteria } \\
\text { Figuivalent Concentration per } \\
\text { Washington Administrative ('ode } \\
\text { 173-303-I00 } \\
\text { * NOTE: Volatile paint constituents } \\
\text { identified in Table } 1-5 \text { (HNF } \\
2000 \text { a) for exclusion cannot be } \\
\text { excluded without objective } \\
\text { evidence, see Section } 1.3 .2 \text { item } 6 \\
\text { (HNF } 2000 \text { a). }\end{array}$ \\
\hline 2 & $\begin{array}{l}\text { Rags Contaminated with } \\
\text { Stripped Paint Waste }\end{array}$ & $\begin{array}{l}\text { radioactive COC list' } \\
\text { 'TC metals --As, Ba, Cd, Cr, Pb, } \\
\text { IIg, Se, } \Lambda g \\
\text { 2-(2-methoxy)-Ethanol, 2- } \\
\text { Phthalocyanito-copper (copper } \\
\text { phthalocyanine), 2,2,4- } \\
\text { Trimethyl-1,3- } \\
\text { pentanediolmonoisobutyrate, 2- } \\
\text { propoxyethanol, Dibutyl } \\
\text { Phthalate, N- Naphthalene, } \\
\text { llydroxypropylmethyl-cellulose } \\
\text { Methyl-2-pyrrolidone, D- } \\
\text { Limonene }\end{array}$ & $\begin{array}{l}\text { radioactive COC list' } \\
\text { Metals confirmed to be present in } \\
\text { paint at concentrations above } \\
\text { screening limits for TC. } \\
\text { Nonvolatile paint constituents. } \\
\text { Toxicity must be evaluated to } \\
\text { determine the contribution to } \\
\text { Dangerous Waste Criteria } \\
\text { Iquivalent Concentration per } \\
\text { Washington Administrative } \\
\text { Codel73-303-100. } \\
\text { *NOTE: Volatile paint constituents } \\
\text { identified in Table I-5 (IINF } 2000 \text { ) } \\
\text { for exclusion cannot be excluded } \\
\text { without objective evidence, see } \\
\text { Section } 1.3 .2 \text { item } 6 \text { (HNF } 2000 \text { ). } \\
\text { Citristrip constituents. Toxicity } \\
\text { must be evaluated to determine the } \\
\text { contribution to Dangerous Waste } \\
\text { Criteria Equivalent Concentration } \\
\text { per Washington Administrative } \\
\text { ('ode } 173-303-100 \\
\text { NoTE: D-Limonene is a } \\
\text { Washington "Toxic D" waste if } \\
\text { present at } 10 \% \text { or greater. }\end{array}$ \\
\hline
\end{tabular}


Table 1-1. Final List of COCs. (5 Pages)

\begin{tabular}{|c|c|c|c|}
\hline WS\# & $\begin{array}{l}\text { Material (Component)/ } \\
\quad \therefore \quad \text { Category }\end{array}$ & $\mathrm{COC}$ & Rationale for Inclusion \\
\hline 3 & $\begin{array}{l}\text { structural shielding that } \\
\text { contains haz metals - lead } \\
\text { bricks, lead shielding }\end{array}$ & $\begin{array}{l}\text { radioactive COC list } \\
\mathrm{Pb}\end{array}$ & $\begin{array}{l}\text { radioactive COC list } \\
\text { Major component in lead shielding }\end{array}$ \\
\hline 4 & $\begin{array}{l}\text { Broken fluorescent and } \\
\text { incandescent light bulbs } \\
\text { (ballasts/tixture assumed not } \\
\text { present in the basin) }\end{array}$ & $\begin{array}{l}{\text { radioactive } \mathrm{COC} \text { list }^{1}}^{\mathrm{TC} \text { metals }-\mathrm{As}, \mathrm{Ba}, \mathrm{Cd}, \mathrm{Cr}} \\
\mathrm{Pb}, \mathrm{Hg}, \mathrm{Se}, \mathrm{Ag}\end{array}$ & $\begin{array}{l}\text { radioactive COC list' } \\
\text { Metals present in fluorescent and } \\
\text { incandescent bulbs }\end{array}$ \\
\hline 5 & $\begin{array}{c}\text { cartridge filters, disposable } \\
\text { personal protective } \\
\text { equipment, plastic, and other } \\
\text { Irash }\end{array}$ & radioactive COC list $^{1}$ & radioactive COC list' \\
\hline 6 & $\begin{array}{l}\text { materials used for decon of } \\
\text { equipment: clotl, paper, } \\
\text { plastic }\end{array}$ & radioactive COC list ${ }^{\prime}$ & radioactive COC list' \\
\hline 7 & $\begin{array}{l}\text { process equipment: heat } \\
\text { exchangers, piping }\end{array}$ & radioactive $\mathrm{COC}$ list' & radioactive $\mathrm{COC}$ list ${ }^{1}$ \\
\hline 8 & $\begin{array}{l}\text { Unpainted demolition } \\
\text { debris, structural steel, } \\
\text { rocks, gravel, metal, glass, } \\
\text { concrete, ceramic, bricks, } \\
\text { roofing material, wood } \\
\text { drywall, siding }\end{array}$ & radioactive $\mathrm{COC}$ list' & radioactive COC list ${ }^{\prime}$ \\
\hline 9 & $\begin{array}{l}\text { materials collected during } \\
\text { general housckeeping: soil, } \\
\text { sawdust, vegetation, debris, } \\
\text { glass, plastic }\end{array}$ & radioactive $\mathrm{COC}$ list' & radioactive COC list ${ }^{\prime}$ \\
\hline 10 & $\begin{array}{l}\text { high-efficiency particulate } \\
\text { air (IIEPA) filters }\end{array}$ & radioactive $\mathrm{COC}$ list ${ }^{1}$ & radioactive $\mathrm{COC}$ list $^{1}$ \\
\hline 11 & $\begin{array}{l}\text { structural steel - fuel storage } \\
\text { racks \& bulkheads; } \\
\text { structures used for fuel } \\
\text { handling }\end{array}$ & $\begin{array}{l}\text { radioactive } \mathrm{COC} \text { list } 1 \text { ? } \\
\mathrm{PCBs}, \mathrm{TC} \text { metals }-\mathrm{As}, \mathrm{Ba}, \mathrm{Cd}, \\
\mathrm{Cr}, \mathrm{Pb}, \mathrm{Hg}, \mathrm{Se}, \mathrm{Ag}\end{array}$ & $\begin{array}{l}\text { radioactive COC list } \\
\text { Metals and PCBs have been } \\
\text { identified in KE Basin Sludge at } \\
\text { concentrations exceeding the TCLP } \\
\text { Total Concentration screening } \\
\text { level. If sludge is incompletely } \\
\text { removed or if underwater items are } \\
\text { porous, then the presence of } \\
\text { residual sludge may cause the items } \\
\text { to be designated as mixed waste. }\end{array}$ \\
\hline
\end{tabular}


Table 1-1. Final List of COCs. (5 Pages)

\begin{tabular}{|c|c|c|c|}
\hline WS\# & $\begin{array}{c}\text { Material (Component)/ } \\
\text { Category }\end{array}$ & $\mathrm{COC}$ & Rationale for Inclusion \\
\hline 12 & $\begin{array}{c}\text { process equipment - pumps, } \\
\text { old canister washer, piping } \\
\text { and piping components, } \\
\text { rubber hoses }\end{array}$ & $\begin{array}{l}\text { radioactive COC } \text { list }^{1,2} \\
\text { PCBs, TC metals --As, } \mathrm{Ba}, \mathrm{Cd} \text {, } \\
\mathrm{Cr}, \mathrm{Pb}, \mathrm{Hg}, \mathrm{Se}, \mathrm{Ag}\end{array}$ & $\begin{array}{l}\text { radioactive COC list' } \\
\text { Melals and PCBs have been } \\
\text { identified in KE Basin Sludge at } \\
\text { concentrations exceding the TCI,P } \\
\text { Total Concentration screening } \\
\text { level. If sludge is incompletely } \\
\text { removed or if underwater items are } \\
\text { porous, then the presence of } \\
\text { residual sludge may cause the items } \\
\text { to be designated as mixed waste. }\end{array}$ \\
\hline 13 & $\begin{array}{c}\text { miscellaneous debris - } \\
\text { electrical cables, light } \\
\text { fixtures, long tools, brushes, } \\
\text { personal protective } \\
\text { equipment, metal, plastic }\end{array}$ & $\begin{array}{l}\text { radioactive COC list }{ }^{1,2} \\
\mathrm{PCBs}, \mathrm{IC}^{\prime} \text { metals } \mathrm{As}, \mathrm{Ba}, \mathrm{Cd}, \\
\mathrm{Cr}, \mathrm{Pb}, \mathrm{Hg}, \mathrm{Se}, \mathrm{Ag}\end{array}$ & $\begin{array}{l}\text { radioactive COC list } \\
\text { Metals and PCBs have been } \\
\text { identified in KE Basin Sludge at } \\
\text { concentrations exceeding the TCLP } \\
\text { Total Concentration screening } \\
\text { level. If sludge is incompletely } \\
\text { removed or if underwater items are } \\
\text { porous, then the presence of } \\
\text { residual sludge may cause the items } \\
\text { to be designated as mixed waste. }\end{array}$ \\
\hline 14 & Canisters/canister lids & $\begin{array}{l}\text { radioactive COC list }{ }^{1.2} \\
\text { PCBs, TC metals - As, Ba, Cd, } \\
\mathrm{Cr}, \mathrm{Pb}, \mathrm{Hg}, \mathrm{Se}, \mathrm{Ag}\end{array}$ & $\begin{array}{l}\text { radioactive COC list' } \\
\text { Metals and } \mathrm{PC} B \text { s have been } \\
\text { identified in } \mathrm{KE} \text { Basin Sludge at } \\
\text { concentrations exceeding the TCLJ' } \\
\text { Total Concentration screening } \\
\text { level. If sludge is incompletely } \\
\text { removed or if underwater items are } \\
\text { porous, then the presence of } \\
\text { residual sludge may cause the items } \\
\text { to be designated as mixed waste. }\end{array}$ \\
\hline 15 & IXMs & $\begin{array}{l}\text { radioactive COC list' } \\
\text { PCBs, 'TC metals } \cdots \wedge \mathrm{s}, \mathrm{Ba}, \mathrm{Cd} \text {, } \\
\mathrm{Cr}, \mathrm{Pb}, \mathrm{Hg}^{3}, \mathrm{Se}, \mathrm{Ag}\end{array}$ & $\begin{array}{l}\text { radioactive COC list' } \\
\text { PCBs in water at concentrations at } \\
\text { or near the reported detection limit } \\
\text { may be expected to bind to the } \\
\text { hydrophobic IXM resin material. } \\
\text { Toxic Metals in water at } \\
\text { concentrations at or near the } \\
\text { detection limit may concentrate to } \\
\text { elevated concentrations in the spent } \\
\text { IXMs. }\end{array}$ \\
\hline
\end{tabular}


Table 1-1. Final List of COCs. (5 Pages)

\begin{tabular}{|c|c|c|c|}
\hline WS $\#$ & $\begin{array}{c}\text { Material (Component)/ } \\
\text { Category }\end{array}$ & $\mathrm{COC}$ & Rationale for Inclusion \\
\hline 16 & $\begin{array}{l}\text { floor tiles/ceiling tiles; } \\
\text { sprayed on ceiling texture or } \\
\text { acoustic surface coatings }\end{array}$ & $\begin{array}{l}\mathrm{Pb}, \text { if painted } \\
\text { asbestos } \\
\text { radioactive } C O C \text { list' }\end{array}$ & $\begin{array}{l}\text { Asbestos containing material } \\
(\mathrm{ACM}) \text { may be painted. If lead } \\
\text { paint is applied, } \triangle \mathrm{CM} \text { must contain } \\
\text { less than } 0.05 \% \text { wt. paint. } \\
\text { The age of the } \mathrm{KE} \text { and } \mathrm{KW} \text { Basin } \\
\text { facilities indicates that asbestos is } \\
\text { likely to be present in numerous } \\
\text { materials. } \\
\text { radioactive } C O C \text { list' }\end{array}$ \\
\hline 17 & $\begin{array}{l}\text { pipe and duct insulation and } \\
\text { insulation mastic; mastic } \\
\text { used as adhesive for plastic } \\
\text { baseboard moldings }\end{array}$ & $\begin{array}{l}\text { asbestos } \\
\text { radioactive COC list' }\end{array}$ & $\begin{array}{l}\text { The age of the KE and KW Basin } \\
\text { facilities indicates that asbestos is } \\
\text { likely to be present in numerous } \\
\text { materials. } \\
\text { radioactive COC list' }\end{array}$ \\
\hline 18 & $\begin{array}{l}\text { mineral based building } \\
\text { insulation in walls and } \\
\text { ceilings }\end{array}$ & $\begin{array}{l}\text { asbestos } \\
\text { radioactive COC list' }\end{array}$ & $\begin{array}{l}\text { The age of the } \mathrm{KE} \text { and } \mathrm{KW} \text { Basin } \\
\text { facilities indicates that asbestos is } \\
\text { likely to be present in numerous } \\
\text { materials. } \\
\text { radioactive COC list }\end{array}$ \\
\hline 19 & $\begin{array}{c}\text { asbestos board (transite) } \\
\text { used in walls, ceilings, } \\
\text { siding }\end{array}$ & $\begin{array}{l}\text { asbestos } \\
\text { radioactive } \mathrm{COC} \text { list }\end{array}$ & $\begin{array}{l}\text { The age of the KE and } \mathrm{KW} \text { Basin } \\
\text { facilities indicates that asbestos is } \\
\text { likely to be present in numerous } \\
\text { materials. } \\
\text { radioactive COC list }\end{array}$ \\
\hline 20 & high temp gaskets and seals & $\begin{array}{l}\text { asbestos } \\
\text { radioactive COC list }\end{array}$ & $\begin{array}{l}\text { The age of the KE and KW Basin } \\
\text { lacilities indicates that asbestos is } \\
\text { likely to be present in numerous } \\
\text { materials. } \\
\text { radioactive COC list' }\end{array}$ \\
\hline
\end{tabular}


HNF -6495

Rev. 0

Table 1-1. Final List of COCs. (5 Pages)

\begin{tabular}{|c|c|c|c|}
\hline WS\# & $\begin{array}{c}\text { Material (Component)/ } \\
\text { Category }\end{array}$ & COC & Rationale for Inclusion \\
\hline
\end{tabular}

'Radiological COCs are H3, Co-60, Ni-63, Sr-90, Sb-125, Cs/Ba-137, Pm-147, Sm-151, Eu-152, Eu-154, Eu-155, U-235, U-238, Pu-238, Pu-239, Pu-240, Pu-241, Am-24I, and Cm-244. Each radionuclide has been included because they meet one or more of the following criteria (1) the radionuclide is part of the N-Reactor uranium fuel cycle process, (2) the radionuclide is not gaseous and has a half-life greater than 1 year, (3) the beta/gamma emitting raldionuclide was estimated to be present at greater than $1 \%$ of the Cs- 137 activity of the waste, and/or (4) the alpha emitting or TRU radionuclide was estimated to be greater than $0.1 \%$ of the CS- 137 activity of the waste. The remaining radionuclides apply to all LLW from the K Basins. See HNF (2000a), Appendix B, Table B-1.

'Radioactive/LLW could potentially designated as TRU or mixed waste if the sludge is incompletely removed, or if the underwater debris itcms are porous.

'Mercury was not detected in sludge; therefore, is not included.

\subsubsection{Step 1: Statement of the Problem}

Debris has been broadly delined by the K Basin ROD (LPA et al. 1999) as all solid waste generated from the CERCLA interim remedial action of KE and KW Basins excluding SNF, sludge, and water. The debris has been previously disposed at the Hanford LLBG or CWC. This debris must be characterized and designated to allow disposal at ERDF or segregation for an alternate disposal pathway, as appropriate. Because the K Basin structures have been designated as an RMA, all materials removed from this area are assumed to be radioactively-contaminated. Most debris will designate as radioactive LLW, although some may designate as radioactive mixed waste, TRU, or mixed TRU. Additional data are needed to designate the waste and evaluate whether it can be disposed of at ERDJ?

\subsubsection{Step 2: Identify the Decisions}

Step 2 presents the logic pathway that is used to resolve the problem. Table 1-2 in the DQO (IINF 2000a) presents the Principal Study Questions, $\Lambda$ lternative Actions, and Decision Statements to resolve the problem that was presented above. Figures $1-1$ and $1-2$ present the decision logic, based on Step 2, which will be used to assess whether waste may be disposed of at ERDF. These figures have been modified in the course of the comment/response process.

\subsubsection{Step 3: Identify Inputs to the Decisions}

Step 3 identified the data needed to resolve each of the Decision Statements identilied in Step 2, as well as the analytical performance requirements (e.g., practical quantitation limit requirement, precision, and accuracy) to support the data. The reader is referred to the DQO for the logic behind the selection of inputs, analytical methods and field techniques, and tables which present these information needs. Because process knowledge will be used to designate waste streams for 
TC metals, PCBs, and asbestos, no analyses will be conducted to support decisions related to these COCs.

\subsubsection{Step 4: Define the Study Boundaries}

Step 4 identifies the geographic (spatial) and temporal boundaries of the facility under investigation, as well as practical constraints that must be taken into consideration in the sampling design. Table 1-5 in the DQO (HNF 2000a) defines the attributes that make up each population of interest. The populations of interest described in this section have been revised slightly to indicate that painted debris will be assumed to not designate for TC constituents. The project at this time does not anticipate a need to encapsulate any painted debris. The project will develop a ratio that considers the painted surface area and mass of an item to determine the need for encapsulation of painted debris. Segregation of the waste will occur by visual inspection. This procedure will use existing data for TC constituents in paint and will be developed independently from this SAP. 
Figure 1-1. K Basin Debris Disposition Decision Logic.

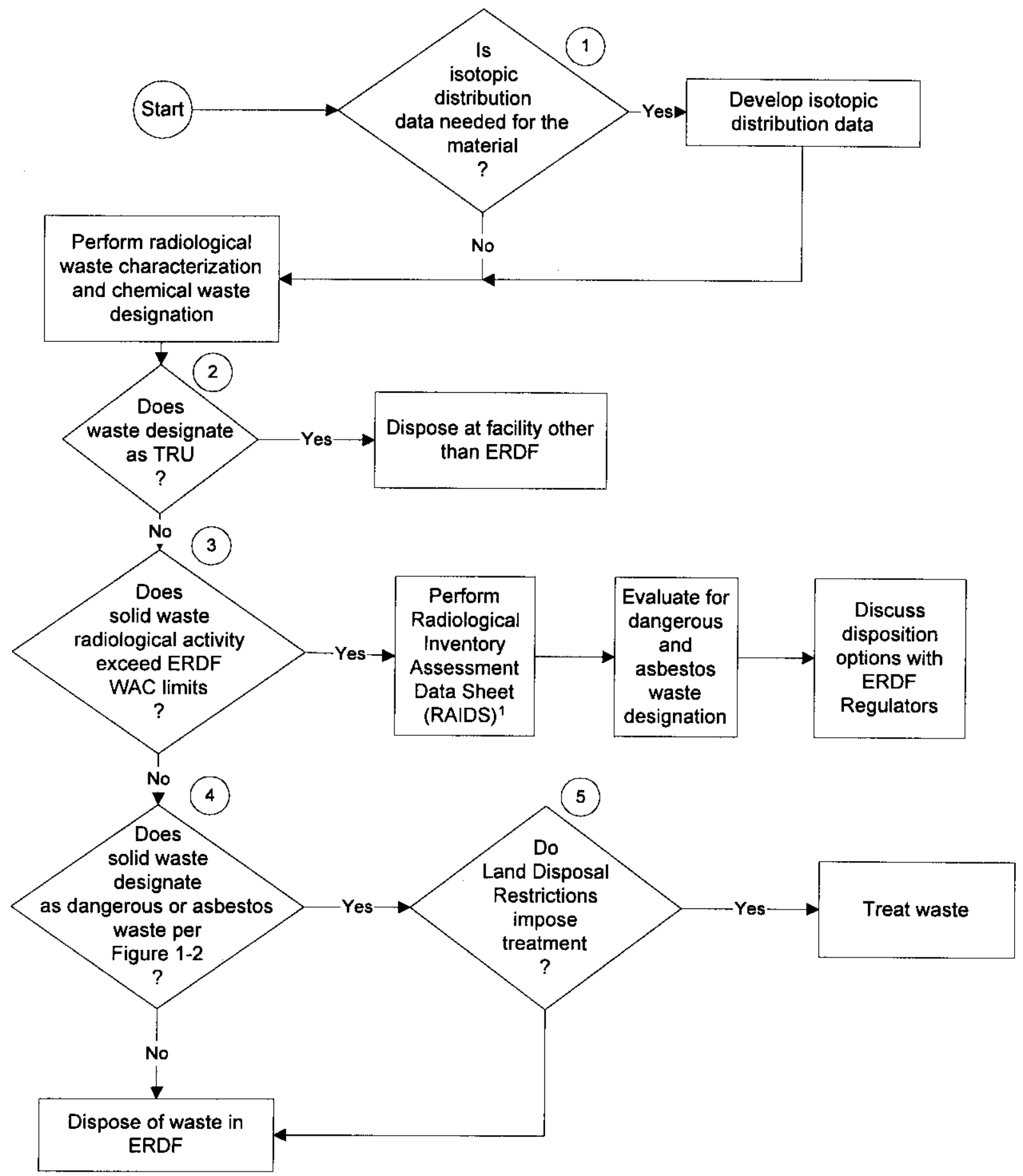

${ }^{1}$ SNF staff will provide the necessary inputs for the ERDF to perform calculations. It is not anticipated that the proposed waste will present any problems for the ERDF inventory. 
Figure 1-2. Chemical Waste Designation Decision Logic.

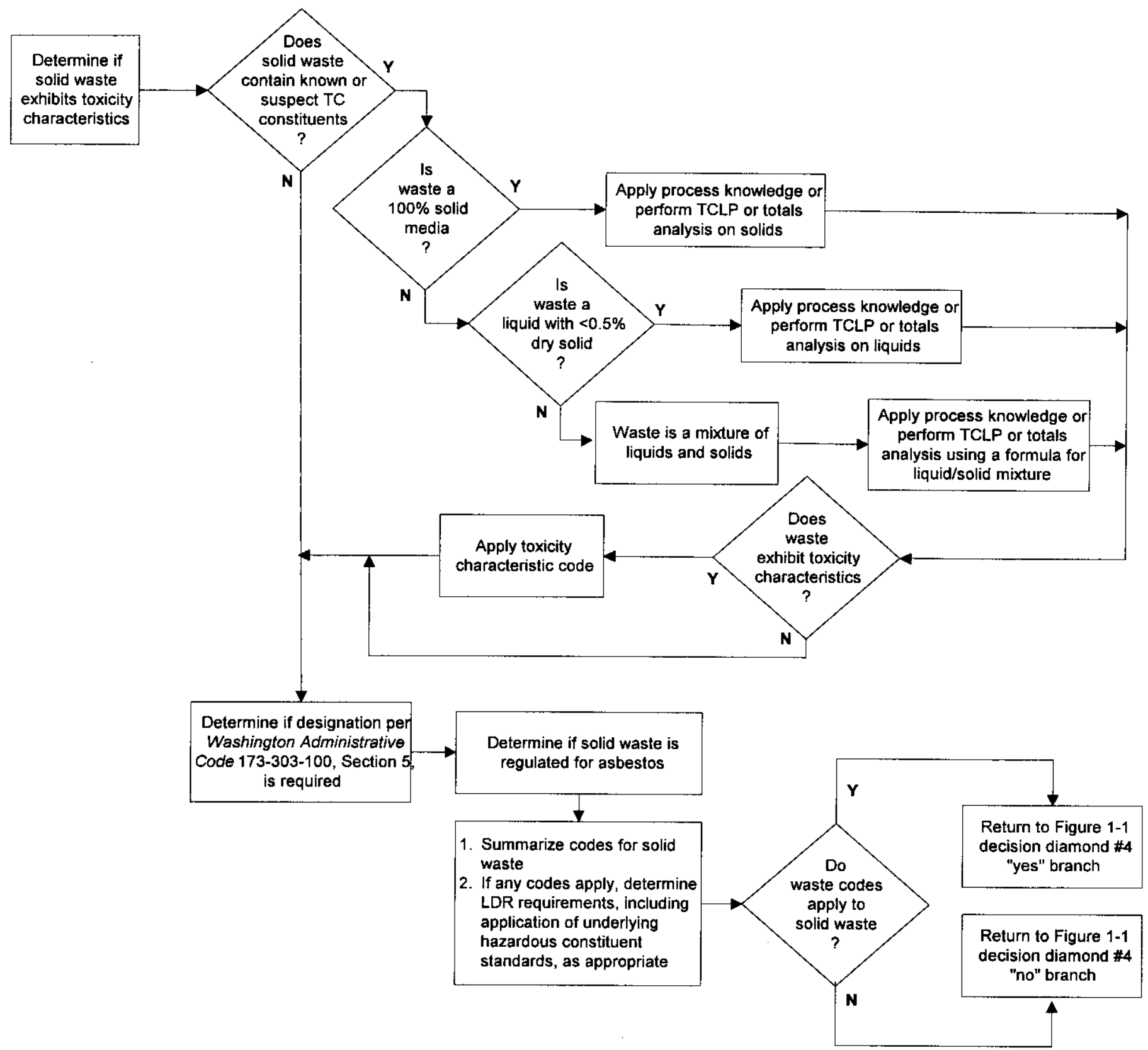


The geographic area of investigation includes the structures that house the $\mathrm{KE}$ and $\mathrm{KW}$ Basins, as discussed in the ROD (EPA et al. 1999). Table 1-6 in the DQO (HNF 2000a) defines the zones or materials within the facility under investigation that have certain similar characteristics.

Decisions for debris disposition (i.e., scale of the decision) will be made for individual articles of equipment, components, or other debris or consolidated packages of debris removed from the facility being investigated. Decisions for the IXM are based on the entire module.

The decisions identified in the DQO Process supporting this SAP (HNF 2000a) apply to removal of all debris covered by the ROD (EPA et al. 1999) during this initial phase of K Basin remedial activities. The decisions may or may not be appropriate for later debris removal activities, particularly for those associated with decontamination and decommissioning of structures not covered by the ROD. The large number of debris items and difficulty associated with collecting representative samples from the variety of matrices supports use of field radiological measurements over sampling and laboratory-based analysis of radionuclides for each item.

\subsubsection{Step 5: Decision Rules}

Step 5 combines information developed in DQO Steps 1 through 4 with a parameter of interest and an action level to provide a concise description of what action will be taken based on the results of data collected. Table 1-7 in the DQO (HNF 2000a) lists the final action level for each Decision Statement and COC; this information has been incorporated into analytical performance requirements later in this SAP.

Table 1-2 (Table 1-8 from the DQO [HNF 2000a]) combines the parameter of interest, scale for decision making, action levels, and alternative actions into separate "IF...THEN..." Decision Rules. These decision rules are the output from the DQO Process and describe actions that will be taken based on the results of data analysis. 
Table 1-2. Decision Rules.

\begin{tabular}{|c|c|}
\hline DR\# & Decisjon Rule \\
\hline 1 & $\begin{array}{l}\text { If the estimated* TRU COCs in the waste do not exeed } 100 \mathrm{nCi} / \mathrm{g} \text {, then the waste will be evaluated per } \\
\text { DRs } \# 2,3 \text {, and } 4 \text { for disposal at IRRDF. } \\
\text { if the estimated TRU COCs in the waste exceed } 100 \mathrm{nCi} / \mathrm{g} \text {, then the waste will not be sent to ERDF. }\end{array}$ \\
\hline 2 & 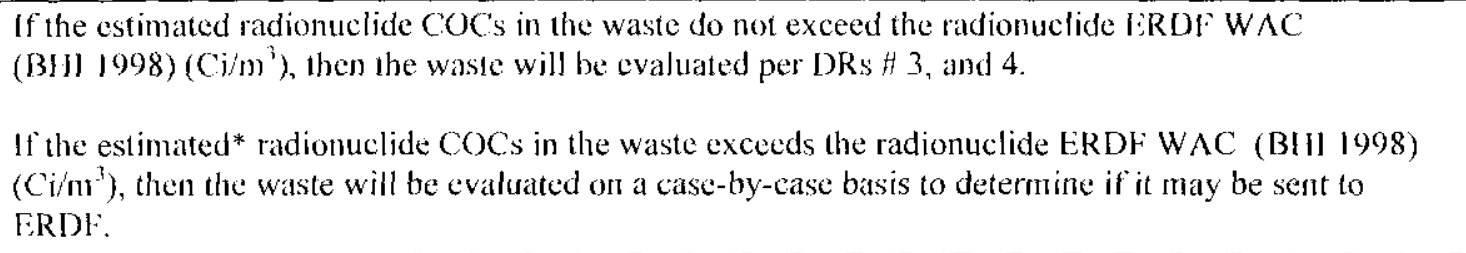 \\
\hline 3 & $\begin{array}{l}\text { If process knowledge, or single sample concentrations of the detected analytical value, indicates that } \\
\text { the materials do not designate as TC or exceed I:RDF W } \mathrm{AC} \text { (BHI 1998), then they will be packaged } \\
\text { for disposal at the ERDI' as I,LW. Waste that designates only as Washington State dangerous will not } \\
\text { require treatment before disposal. } \\
\text { It process knowledge, or single sample concentrations of the detected analytical vafue, indicates that } \\
\text { the materials designate as TC, state dangerous extremely hazardous waste (EHW), or exceed ERDI: } \\
\text { WAC (BHII } 1998 \text { ), then they will be managed through the appropriate treatment or packaging } \\
\text { requirement and disposed of at ERDF. }\end{array}$ \\
\hline 4 & $\begin{array}{l}\text { If process knowledge or any detected analytical sample value dictates LDR imposed treatment, then } \\
\text { debris materials will be treated with macro-encapsulation and disposed at ERDF. Materials that do not } \\
\text { qualify as debris will be managed appropriately according to their designation. } \\
\text { If process knowledge or none of the detected analytical sanple values dictate LDR imposed treatment } \\
\text { of the materials, the debris will be disposed in ERDJ without additional treatment. }\end{array}$ \\
\hline
\end{tabular}

* Radionuclide content estimated from dose to curic conversions.

DR - Decision Rule

\subsubsection{Step 6: Limits on Decision Error}

This section of a DQO generally is used to establish the parameters for a statistically-based sample design. The SAP at this time does not anticipate that a statistically-based approach will be used. Debris will be evaluated through surveys of all materials, coupled with judgmental sampling, as appropriate. The reader is referred to Step 6 in the DQO (HNF 2000a) for additional details. 
1.2.6.1 Radioactive Waste. Each waste container will be surveyed or will contain previouslysurveyed waste. An estimated COC inventory for that waste container will be derived from survey data versus isotopic ratios from previous or contingency sampling measurements. The sample design is judgmentally developed for the materials or components that will ultimately be placed in the shipping container. The project may use survey data to determine relationships between debris weight and CS-137 inventory. If such relationships are developed, their use may be proposed as a modification to this SAP.

1.2.6.2 Potentially Chemically Contaminated Waste. No sampling for chemical constituents is currently planned for the debris. The Basin water flowing into the IXM currently is sampled routinely and the radionuclide load estimated (WHC 1996f).

1.2.6.3 Paint Waste, Painted Debris, and Underwater Debris. Paint waste will be encapsulated; therefore, no sampling is needed to designate those wastes. The lead and cadmium inventory of painted debris, based on the ratio of the painted surface area to the mass of debris being disposed, will be used to designate the painted debris for appropriate disposal.

Debris removed from the basins will be rinsed and/or pressure washed to remove potential TC metals and PCBs. Previous studies have indicated that washing removes the metals and PCBs on debris that has been in contact with the sludge (WHC 1996d). Calculations supporting these studies, which were part of a previous profile used for disposal at the CWC, are presented in Appendix D of the DQO Process (HNF 2000a).

Some debris removed from the basins may be contaminated from sludge. Because of the radionuclide contamination, $\mathrm{PCBs}$, and metals concentrations in the sludge, residual sludge could potentially cause debris to designate as mixed, TRU, or mixed -TRU waste. Accumulated sludge on the debris will be removed through a pressure wash, conducted under water. This procedure is presumed to reduce sludge and associated chemical contaminants to levels that are below regulatory concern. The removal of sludge will be assessed visually.

Lead bricks and shielding, debris designated as mixed waste, and debris that cannot be readily evaluated for compliance with LDR criteria after decontamination, will be designated as hazardous based on process knowledge, collected, and encapsulated for disposal at ERDF. Macro-encapsulation is a compliant alternative treatment technology for hazardous debris according to 40 CFR 268.45 .

Ion-exchange modules will be drained of free-flowing liquids and managed as debris in accordance with the ROD (EPA et al. 1999). The EPA has indicated that the unit, including the IX column and concrete shell, constitutes a HIC, which is equivalent to encapsulation (see HNF 2000a, Appendix B). The project will proceed, based on this interpretation. Section 2.3 summarizes sampling frequencies and locations for collection of water used to calculate the constituent loading on the IXM.

Table 1-3 summarizes sampling frequency and locations. 
HNli-6495

Rev. 0

Table 1-3. Summary of Sampling Frequencies and Locations.

\begin{tabular}{|c|c|c|c|}
\hline $\begin{array}{c}\text { Material } \\
\text { (Components)/ } \\
\text { Categories }\end{array}$ & $\begin{array}{l}\text { Sample Collection } \\
\text { Methodology }\end{array}$ & Sampling Frequency & Sampling Location \\
\hline $\begin{array}{l}\text { All waste streans } \\
\text { except fucl canisters } \\
\text { and IXMs }\end{array}$ & $\begin{array}{l}\text { Measurement of external } \\
\text { dose rate, NDA, gamma } \\
\text { spectroscopy, or sampling } \\
\text { and laboratory analysis as } \\
\text { appropriate to deternine } \\
\text { TRU and radiological } \\
\text { COC content. }\end{array}$ & $\begin{array}{l}\text { Every debris for which an } \\
\text { estimate of radionuclide content } \\
\text { is desired. }\end{array}$ & $\begin{array}{l}\text { Survey measurements } \\
\text { will be performed on the } \\
\text { waste packages, as } \\
\text { described in } \\
\text { Section } 2.2 .6 \text {. } \\
\text { Measurements may be } \\
\text { taken on individual } \\
\text { debris items, or a } \\
\text { suitable container of } \\
\text { debris. }\end{array}$ \\
\hline Fuel canisters & $\begin{array}{l}\text { Measurement of external } \\
\text { dose rate, NDA, or } \\
\text { gamma spectroscopy to } \\
\text { determine TRU and } \\
\text { radiological COC content. }\end{array}$ & $\begin{array}{l}\text { All fuel canisters may be } \\
\text { measured individually or in } \\
\text { larger containers, depending on } \\
\text { linal survey calibration } \\
\text { availability. }\end{array}$ & $\begin{array}{l}\text { Survey measurements } \\
\text { will be perforned on the } \\
\text { waste, as described in } \\
\text { Section } 2.2 .6 \text {. } \\
\text { Measurements may be } \\
\text { taken on individual } \\
\text { debris items, or a } \\
\text { suitable container of } \\
\text { debris. }\end{array}$ \\
\hline $\begin{array}{l}\text { Water associated } \\
\text { with IXM }\end{array}$ & None & $\begin{array}{l}\text { Radionuclide load for each IXM } \\
\text { will be calculated based on the } \\
\text { procedures on the SNF Project's } \\
\text { "Basin Water Quality Control } \\
\text { Procedure" (OP-02-025) and } \\
\text { IXM characterization plan } \\
\text { (WIIC 1997). }\end{array}$ & See Section 2.3 \\
\hline
\end{tabular}




\subsection{QUALITY ASSURANCE PROJECT PLAN}

\subsection{PROJECT MANAGEMENT}

The following section identifies the individuals or organizations participating in the project and discusses specific roles and responsibilities. This section also discusses quality objectives for measurement data and discusses special training requirements for staff performing the work.

\subsubsection{Project and Task Organization}

Figure 2-1 presents the organization chart for sampling/analysis and waste management interfaces to ERDF.

\subsubsection{Roles and Responsibilities}

This section identifies the responsibilities of various organizations supporting $\mathrm{K}$ Basin debris removal and disposal activities that collect, analyze, survey, or assess results of data for waste disposal.

\section{K Basin Operations Support Sample Management Representative}

- Maintain operating procedures as custodian, and revise such procedures to perform basin water sampling that include collection, chain of custody, packaging, and shipping procedure.

- Maintain sample analysis records in a 2-hour-rated fire resistant file cabinet, along with trending and tracking IXM accumulation radionuclides during the operating life of each individual IXM.

- Receive data packages.

- Perform or contract data review.

- Maintain copies of radiological survey records and assemble into files to support waste characterization and designation.

\section{Nuclear Process Operators}

- Perform sampling.

- Document sampling activities in a controlled logbook.

- Initiate chain of custody.

- Package and ship samples to 222-S Laboratory, or other off-site laboratory. 
HNF-6495

Rev. 0

Figure 2-1. Sampling/Analysis and Waste Management Organization Chart.

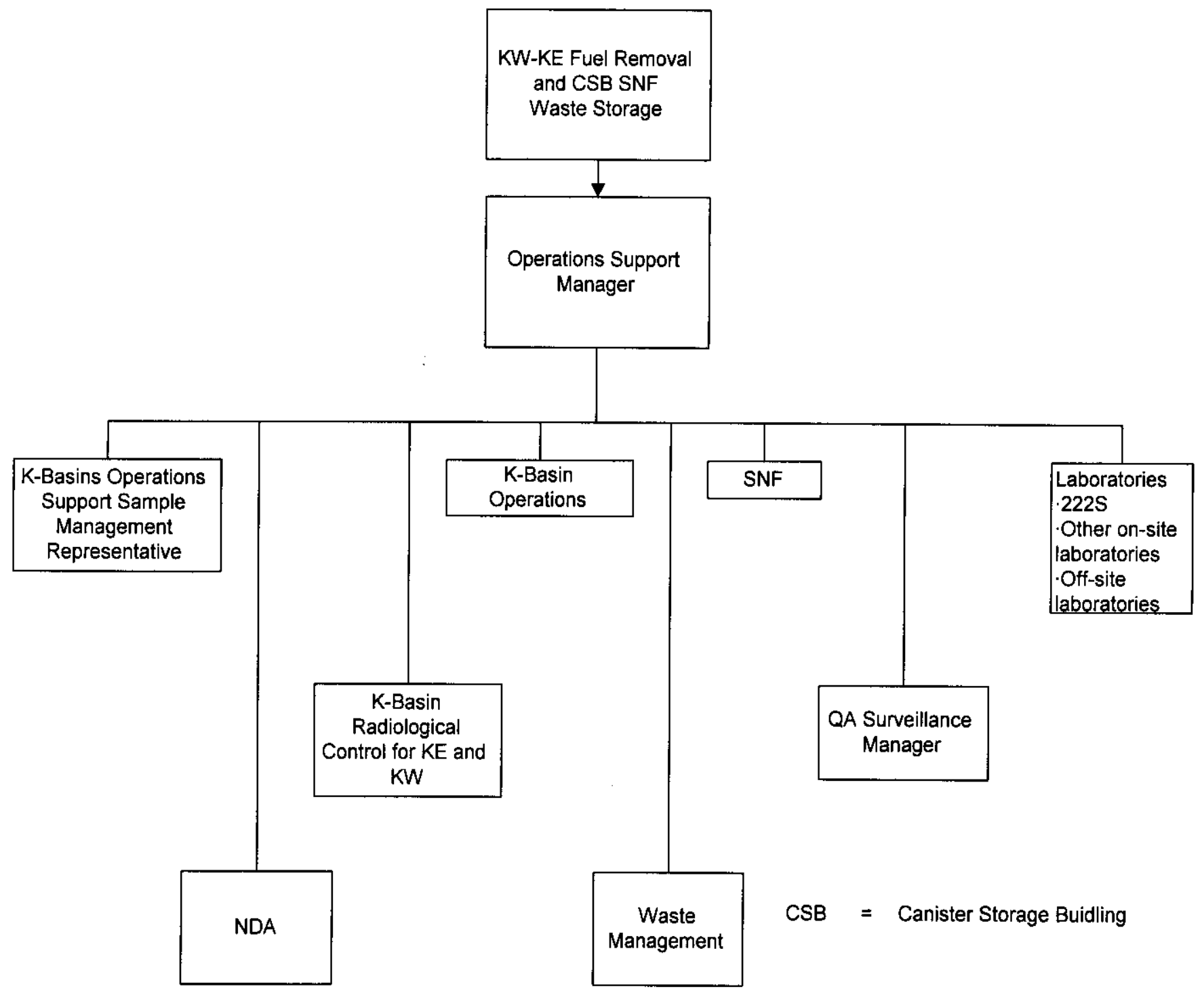




\section{Laboratory(ies) (i.e., 222-S, Waste Sampling and Characterization Facility [WSCF], pre-selected off-site contract laboratories)}

- Receive samples and initiate internal chain of custody.

- Provide specified radiological or non-radiological analyses.

- Provide specified data package to the Operations Support Sample Management Representative.

\section{K Basin Operations Support Manager (or designee)}

- Oversees sample management program.

- Authorizes new radionuclide ratios to be applied to waste as needed.

- Obtain additional analytical services such as non destructive analysis as needed.

\section{Radiological Control Organization}

- Conduct specified surveys/NDA.

- Provide dose rate data for sample collection, packaging, shipment.

- Provide the Radiological Work Permit.

\section{Waste Management}

- Designate waste based on survey/laboratory results and calculated radionuclide content.

- Ship waste or sample for analysis.

- Review data used to designate waste.

\section{Quality Assurance Organization}

- FH quality assurance (QA) has the option to conduct random surveillance to verify compliance with requirements of this plan.

\subsubsection{Special Training Requirements/Certification}

Hazards associated with radiation and radiological contamination are well characterized in the $\mathrm{K}$ Basins. The Hanford Site Radiological Control Manual (HSRCM) (DOE-RL 1996) addresses worker training requirements, visitor training and escort requirements, dosimetry monitoring, posting, and required radiological surveillance. The specific training required by $29 \mathrm{CFR}$ 1910.120 is implemented in the HSRCM. Training requirements for this project are discussed in Section 7 of the K-Basins Interim Remedial Action Health and Safety Plan (HASP)

(HNF 2000b). Project specific training requirements and references are discussed below. 
In the event that a worker may have a reasonable possibility of exposure to hazardous chemicals while performing a specific remediation task in the K Basins, the Facility Operations Manager will ensure that the worker has the appropriate level of training, in accordance with 29 CFR 1910.120, before the work is performed.

SNF Project Administrative Procedure AD-14-004, "Radiological Area Access Control," defines training requirements for various circumstances applicable to entry into K Basins. Training requirements in this procedure apply to all individuals who are required to have access to the K Basins.

Job-specific training requirements for SNF Project personnel are outlined in Procedure TN 8-001-08, "General Training Administration." This procedure covers facility orientation training, Hanford General Employee Training (HGET), facility emergency plan, SNF Project orientation, initial and continuing training, on-the-job training, required reading and drills. The training requirements for each employee are determined using a graded-approach and documented in the appropriate Training Matrix.

All visitors, general employees, or members of the public, will have training or instruction prior to entry to the K Basins per the requirements of SNF AD-14-004.

\subsubsection{Quality Objectives and Criteria for Measurement Data}

The QA objective of this plan is to develop implementation guidance that will provide data of known and appropriate quality. Data quality is typically assessed by representativeness, comparability, accuracy, precision, and completeness. Definitions of these parameters are described below. The applicable quality control (QC) guidelines, quantitative target limits, and levels of effort for assessing data quality are dictated by the intended use of the data and the nature of the analytical method. A summary of COCs for each media is provided in Table 1-1 of the DQO (HNF 2000a). The analytical methods, laboratory detection limits, and sample size for COCs that will be measured are presented in Tables 2-5 for water samples that will be used to characterize IXMs. Table 2-6 provides the same information for contingency samples. The COCs that are not listed in these tables will be estimated based on radionuclide ratios in the waste as discussed in Section 2.2. Quality control parameters of accuracy and precision that are to be applied to water or contingency characterization samples are presented in Table 2-1. The nomenclature used to describe quality parameters is contained in the following discussion.

Representativeness is a measure of how closely measured results reflect the concentration of radiological constituents distributed in the sample matrix. Sampling plan design, sampling techniques, and sample handling protocols (e.g., storage, preservation, and transportation) have been developed and are discussed in subsequent sections of this document. The documentation will establish that protocols have been followed and sample identification and integrity ensured.

Comparability expresses the confidence with which one data set can be compared to another. Data comparability will be maintained by using standard documented procedures, consistent methods, and units. Fixed laboratory methods for analytes and target detection limits are listed in 
Table 2-5. Actual detection limits will depend on the sample matrix, constituent radionuclides, sample quantity available, and will be reported as defined for the specific samples. Detection limits are functions of the analytical method utilized to provide the data and the quantity of sample available for analyses. In the water and contingency sampling, sufficient sample quantity is expected to be available with sufficient radionuclide activity to perform the analyses.

Accuracy is an assessment of the closeness of the measured value to the true value. Accuracy of chemical test results is assessed by spiking samples with known standards and establishing the average recovery. A matrix spike is the addition to a sample of known amounts of a standard compound similar to the compounds being measured. Radionuclide measurements that recuire chemical separations use this technique to measure method performance. For radionuclide measurements that are analyzed by gamma spectroscopy, laboratories typically compare results of laboratory Control Samples against known standards to establish accuracy. Usually, only a few target analytes are selected for analysis for gamma spectroscopy (i.e., cesium-137, cobalt-60, cic.). Validity of calibrations are evaluated by comparing results from measurement of standard to known values and/or by generation of in-house statistical limits. Table 2-1 lists the accuracy targets for fixed laboratory analyses for the project.

Precision is a measure of the data spread when more than one measurement has been taken on the same sample. Precision can be expressed as the relative percent difference for duplicate measurements. Precision targets for lixed laboratory analyses are listed in Table 2-1. Monthly water samples are collected as a timed composite, and thus there may not be enough sample for a duplicate. If that is the case, precision will be estimated from laboratory matrix spikes or other suitably data.

Completeness is a comparison of the valid data required to the amount of valid data obtained from the analytical measurement process and the complete implementation of delined field procedures. The completeness objective for this $\mathrm{S} \Lambda \mathrm{P}$ is set at $90 \%$. Completeness will be assess by waste stream on an analyte-specilic basis. If the completeness objective is not met, additional samples will be collected and analyzed.

Table 2-1. Target Accuracy and Precision of Laboratory Methods for Water and Contingency Sampling.

\begin{tabular}{|c|c|c|}
\hline Matrix & $\begin{array}{c}\text { Accuracy for Radionuclides } \\
\text { (Percent Recovery) }^{2}\end{array}$ & $\begin{array}{c}\text { Precision for Radionuclides } \\
\text { (Relative Percent Difference) }^{3}\end{array}$ \\
\hline Solids & $70-130 \%$ & $\pm 30 \%$ \\
\hline Water & $80-120 \%$ & $\pm 20 \%$ \\
\hline
\end{tabular}

'Accuracy and precision are based on published analy tical methods for waste analyses (see Tables $2-5$ and 2-6).

? Percent recovery - ([amount measured in spiked sample-amount in unspiked sample]/ spike added)*100.

"Relative percent difference - (|result 1-result 2]/average result)*ioo. 


\subsubsection{Documentation and Records}

Field logbooks contain area and task specific information. Field logbooks that are used during collection of samples for waste characterization will be identified as a quality record and will be maintained as such.

Maintenance of field documents will be in accordance with the Hanford Analytical Quality Assurance Requirements Documents (HASQARD) (DOE-RL 1998) Volume II, "Sampling Technical Requirements," Section 4.1.2, "Field Logbook," or equivalent.

\subsection{SURVEY/DATA ACQUISITION}

The following sections present the logic and requirements for radiological survey. The radiological dose rate survey data will be used to estimate radiological content of the waste. Periodic surveys with a hand held two channel gamma detector will also be performed, and if the waste is determined to be anomalous (as defined in Section 2.2.3), it will be set aside and subjected to more extensive NDA and/or sampling and analysis. The approach for contingency sampling and NDA is discussed in Section 2.4 of this SAP. The sections below address requirements for instrument calibration and maintenance, and data management. The project uses a graded-approach to characterize waste generated at the $\mathrm{K}$ Basin.

Waste generated at K Basins will be processed to comply with ERDF WAC (BHI 1998) criteria and packaged according to Procedure OP-46-006 ("Processing Contaminated Waste for ERDF Disposal"). Most of the waste removed from the basin water will be treated as restricted contaminated waste ( $\mathrm{RCW})(\mathrm{OP}-46-006)$ because of several considerations. This is in part a result of previous measurements of total and smearable contamination from the fuel canisters and pipe hangers washed and removed from the basin. These data indicate that the waste would not have passed the ERDF surface contamination criteria of $100,000 \mathrm{dpm} / 100 \mathrm{~cm}^{2}$ beta/gamma and $400 \mathrm{dpm} / 100 \mathrm{~cm}^{2}$ alpha (as listed in Procedure OP-46-006). It is also in part due to concern that it may be difficult to measure the loose and smearable contamination levels in the environs of the basin prior to wrapping the waste with plastic, putting it in a bag (or other method of fixing radioactive contamination) and maintain as low as reasonably achievable (ALARA) considerations. In addition, all of the surfaces of each individual piece of waste being removed from the $\mathrm{K}$ Basins may not be accessible. If large pieces of waste are encountered above the water that have all of the surfaces accessible, some of the waste may be surveyed with portable handheld beta/gamma and/or alpha instrumentation and designated as non-restricted contaminated waste (NRCW) as appropriate. Such surveys will be conducted per the appropriate instrument procedure. Restricted contaminated waste will be wrapped in plastic, placed in plastic bags, as described in Procedure OP-46-006. Other alternatives to plastic wrap (e.g., sprayed fixative) may be explored and used with ERDF agreement.

Packaged waste (e.g., individual pieces, bags, barrels, boxes as appropriate) will be surveyed per appropriate instrument procedures to assure that the outside of the waste debris package meets surface contamination limits, documented per HNF-PRO-1892 ("Documentation of Radiological 
Surveys") and weighed. The waste debris package will then be surveyed to obtain the dose rate $(\mathrm{R} / \mathrm{hr}$ ) from the waste package. The dose rate obtained from the waste package will be use to estimate the cesium-137 curie content of the waste as discussed below. Utilizing the ratios of the COCs to cesium-137 as discussed in Section 2.2.1, the radionuclide content of the waste will be estimated.

During waste removal operations, ten waste packages out of each 100 prepared will be randomly chosen (see Section 2.2.3) and measurements will be performed with a gamma detector that is capable of measuring at least two different energy regions of the spectra. It is anticipated that a hand-held sodium iodide ( $\mathrm{NaI}$ ) detector with an associated ratemeter/scaler, which has the ability to measure two gamma energy regions of interest, will be used. One region of the spectra will be centered on the cesium/barium-137m gamma peak at $666 \mathrm{keV}$. The other region will be an open window that includes the gamma emissions from europium-152/154/155, antimony-125, and cobalt-60, as well as cesium-137. Evaluation of ratios of counts from the two regions will be used to determine if the waste is anomalous. Anomalous waste is defined for this project as any waste where the ratio of cesium/barium- $137 \mathrm{~m}$ counts per minute to the combined counts per minute of cesium, cobalt, antimony, and europium isotopes exceeds preset ratios that are considered characteristic of the waste. These ratios and their application are discussed in more detail in the following sections and presented in Table 2-4.

Any waste that is considered anomalous will be set aside and may measured with a more sophisticated NDA approach or sampled and analyzed in order to establish an appropriate radionuclide mix for the waste in question. These contingency/NDA sampling approaches are discussed in Section 2.4.

\subsubsection{Dose Rate to Curie Conversion}

The measurement of dose rate on various sized containers will be obtained according to the methods discussed in WHC-SD-WM-PROC-020 (Procedure for Categorizing and Inventorying Waste in Standard Containers [WHC 1996g]). The technical basis for this procedure is presented in WHC-SD-WM-RPT-267, Basis for Dose Rate to Curie Assay Method (WHC 1996a). Briefly, the method utilizes a family of curves that relate the measured dose rate (R/hr) to the cesium-137 curie content of the waste. Although the technical basis document (WHC 1996a) was prepared for tank waste, the basic premise of the document is that the major contributor to the measured dose rate is cesium-137. That same premise is appropriate for the $\mathrm{K}$ Basin debris. Although other gamma emitters do exist in the $\mathrm{K}$ Basin debris, the most common (cobalt-60, europium-152, europium-154, and europium-155) generally are less than $10 \%$ of the cesium- 137 content. By using the conservative assumption that all measured dose rate is from cesium-137, other gamma-emitting radionuclides, if present, would be lead to an overestimation of the cesium-137 content of the waste. All other radionuclides will be estimated based on use of specific ratios of COC radionuclides to $\mathrm{Cs}-137$ for the waste in question. Thus, the final estimated radionuclide content would likely be overestimated if gamma-emitting radionuclides were present in greater abundance than anticipated. 
Each size and type of waste container (e.g., 55 gallon, 85 gallon, $4 \mathrm{ft}$ by $4 \mathrm{ft}$ by $8 \mathrm{ft}$ box) has a specific curve that has been constructed by a combination of computer generation and measurement. The conversion is also dependent on the density of the waste material so the curves are displayed as curies of cesium-137 per $\mathrm{R} / \mathrm{hr}$ versus net waste weight for each type of waste container.

Table 2-2 lists the waste container types anticipated and whether or not there is a current dose to curie curve. The detection limits for cesium-137 that are listed assume that the lowest dose rate measurement that will be reported will be $0.5 \mathrm{mR} / \mathrm{hr}$. This is based on discussion with $\mathrm{K}$ Basin radiological protection personnel. The achievable detection limits for cesium-137 will be directly proportional to the lowest net dose rate that can be reported. In order to list conservative detection limits for cesium-137, the curies of cesium-137 per R/hr that was used for each container type was chosen from the maximum weight on the specific curve. Only measurements performed on containers for which a dose to curie curve exists may be used to estimate radionuclide content of the waste.

\subsubsection{Cesium-137 Curie to Radionuclide Content Estimate for Above- and Below- Water Waste}

During the DQO Process, a final list of COCs was generated. The logic and approach for selecting the final list of COCs is discussed in Appendix B of the K Basin DQO (HNF 2000a). The estimate of radiological content for waste will rely on ratios of various COCs to a measured cesium-137 content. The cesium-137 content will be estimated through dose to curie conversions that are discussed above. The ratios of various COCs to cesium-137 have been estimated based on review of available analytical data and computer calculations of estimated content of fuel and sludge from the $\mathrm{KE}$ and $\mathrm{KW}$ Basins. The following sections discuss the use of estimated ratios to characterize waste.

\subsubsection{Waste Removed from the Fuel Storage Basin Water (Waste Streams 11-14)}

(HNF 2000a). Fuel in both basins was the primary initial source of radioactive COCs in the water and in the basin sludge. Physical and chemical processes occurring as the basin water contacted the fuel are known to alter the ratios of various radionuclides to cesium- 137 from those in the raw fuel. In $\mathrm{KE} \mathrm{Basin,} \mathrm{fuel} \mathrm{is} \mathrm{the} \mathrm{major} \mathrm{contributor} \mathrm{to} \mathrm{basin} \mathrm{floor} \mathrm{sludge.} \mathrm{In} \mathrm{KW}$ Basin, there is a much less direct connection to the fuel since the fuel canisters remained largely intact. In both $\mathrm{KE}$ and $\mathrm{KW}$ Basins, it was assumed that fuel and basin floor sludge were the primary contributors to contamination of debris items within the basins. 
For waste removed from beneath the water of the basins, available data indicate that the radionuclide mix remaining on fuel canisters and metallic waste (e.g., pipe hangers) would be similar (waste streams 11, 14, HNF 2000a). Both will be washed prior to removal. Observed isotopic ratios from smears and NDA on washed metal items were approximated more closely by the radionuclide ratios estimated in the fuel (105-K Basin Material Design Basis Feed Description for Spent Nuclear Fuel Project Facilities [HNF 2000b]) than in the basin sludge (HNF 2000c). This was based on the evaluation of data from several documents in concert with analytical results and smears. Thus, the estimated or measured cesium-137 radionuclide content will be multiplied by the ratios in column $3(\mathrm{KE})$ and $6(\mathrm{KW})$ of Table $2-3$. The data considered for this assessment and additional discussion are provided in Appendix A of this SAP.

For debris other than power-washed fuel canisters or metallic items (waste streams 12, 13, HNF 2000a), it was determined that the basin floor sludge would be the appropriate source term. This was based on reasoning that those items such as rubber hose, animal parts, and other non-metallic debris would have been contaminated more by sludge particles lodging in the cracks of the material and washing would likely be much less effective than for the canisters and metallic waste. Thus, the estimated or measured cesium-137 radionuclide content will be multiplied by the ratios in columns $4(\mathrm{KE})$ and $6(\mathrm{KW})$ in Table 2-3. If contingency sampling or NDA provides direct measurement of alternative radionuclide ratios, they may be applied. The data considered for this assessment and additional discussions are provided in Appendix A. 


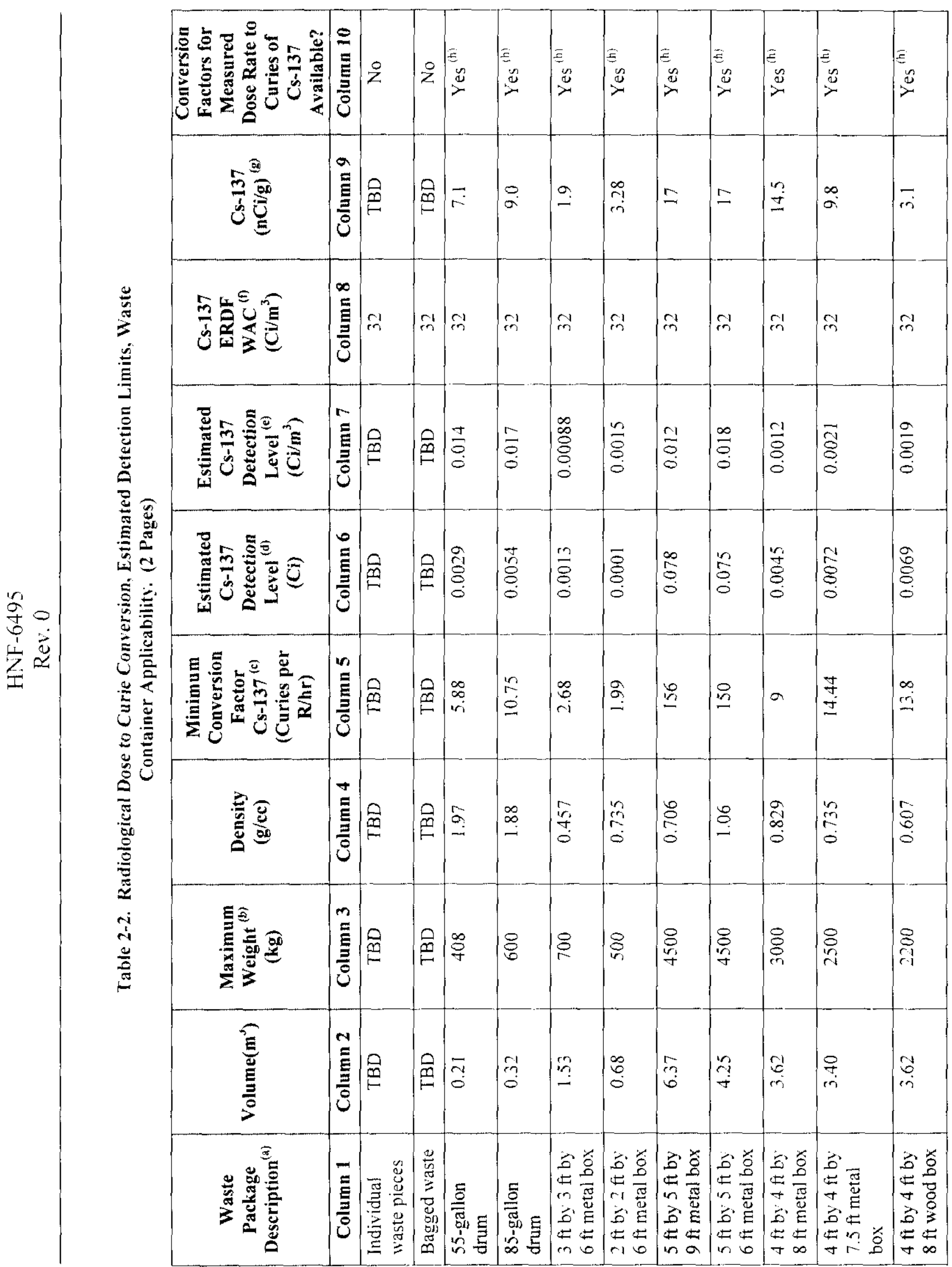




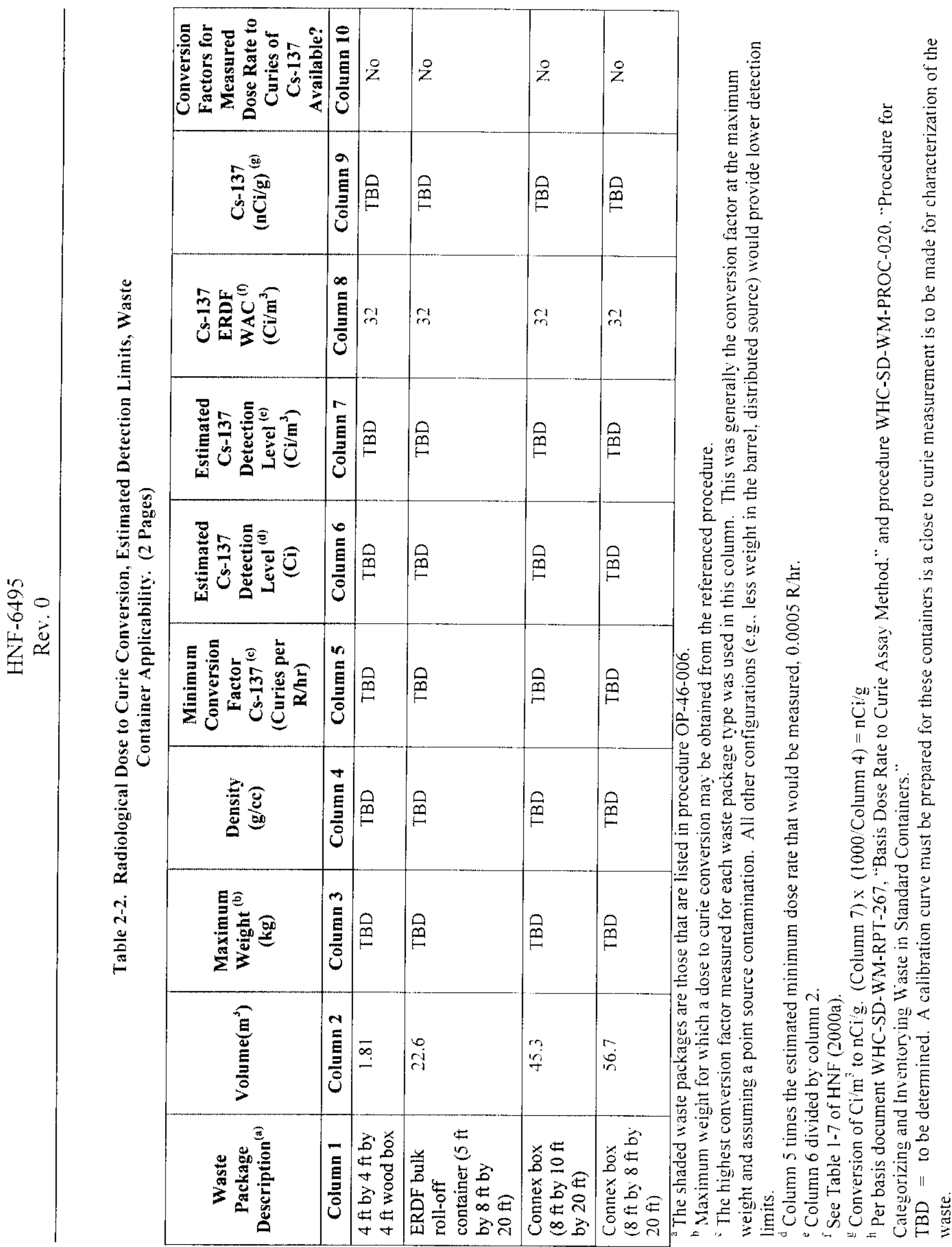




\subsubsection{Waste Generated Above Water Near the Fuel Storage Basin (Waste Streams 1-10,} 16-20, HNF 2000a). For areas above the basin water surface it was reasoned that the contamination would have come from a variety of activities resulting in basin sludge and basin water being deposited during various operational activities. The sludge and water would dry and some part of the contamination would become airborne. Thus, it was reasoned that the air filter data obtained from both $\mathrm{KE}$ and $\mathrm{KW}$ Basins would be a useful measurement of the radionuclide ratios for contamination in the above-water portions of the basins. Available air filter data were summarized as a percent of cesium-137 and compared to ratios previously obtained by sampling and analysis (Characterization of Radionuclide Waste at 100 Area [WHC 1990]). A full listing of the data used is provided in Appendix A. If data were available in the WHC report (WHC 1990) or from the air samples, the highest ratio of the two was used. If no data were available for a specific radionuclide, then the sludge ratio was used. If there were no data for a specific radionuclide in the sludge, then fuel ratios were used. The final ratios selected are listed in column $5(\mathrm{KE})$ and $7(\mathrm{KW})$ in Table 2-3. Thus, the estimated or measured cesium-137 radionuclide content will be multiplied by the ratios in Table 2-3 to estimate the radionuclide content of the waste. Appendix A provides additional discussion of this evaluation.

2.2.2.3 Asbestos. Asbestos will be identified/managed through the FH asbestos abatement program per procedure HNF-PRO-408, "Asbestos-Facility Management/General Industry" and HNF-PRO-338, "Asbestos Control-Construction Industry." If asbestos is identified it will be surveyed and the radionuclide content determined the same way as discussed above for all of the other waste streams.

\subsubsection{Anomalous Waste}

In order to detect waste that deviates significantly from the expected ratios in Table 2-4, approximately $10 \%$ of the waste packages generated will be randomly selected and surveyed with a gamma detector. The 10 waste packages will be chosen by generating random numbers for groups of 100 packages. Ten random numbers will be generated. The random measurements performed on the waste packages should be on the same size package as used to characterize the waste using dose-to-curie conversions. If measurements are being performed on bags of waste, then 10 bags out of each hundred will be measured. The gamma detector will be one capable of recording at least two different portions of the gamma spectrum. The two parts of the gamma spectrum will include one energy range centered on the $660 \mathrm{keV}$ gamma emission of cesium/barium $-137 \mathrm{~m}$ and one portion that includes the gamma emissions from cobalt- 60 , antimony- 125 , cesium/barium- $137 \mathrm{~m}$, and europium-152/154/155. The current estimated ratios of cesium-137 to the sum of the other radionuclide in the waste source terms are as shown in Table 2-4. Also shown in Table 2-4 is the ratio range that must be exceeded to indicate that the waste is anomalous. If below-water, pressure-washed waste (waste streams 11, 14, HNF 2000a) from $\mathrm{KE}$ falls below the anticipated 
Table 2-3. COC Radionuclide Ratios to Cesium-137 for Characterization of $\mathrm{K}$ Basin Waste.

\begin{tabular}{|c|c|c|c|c|c|c|}
\hline $\begin{array}{c}\text { Radionuclide } \\
\text { Name }\end{array}$ & $\begin{array}{l}\text { Radionuclide } \\
\text { Symbol }\end{array}$ & $\begin{array}{c}\text { Chosen Ratio for } \\
\text { KE Below Water } \\
\text { Washed Metal } \\
\text { Debris }\end{array}$ & $\begin{array}{c}\text { Chosen Ratio for } \\
\text { KE Below Water } \\
\text { Unwashed or } \\
\text { Non-Metal } \\
\text { Debris }\end{array}$ & $\begin{array}{c}\text { Chosen Ratio } \\
\text { for KE } \\
\text { Above Water } \\
\text { Debris }\end{array}$ & $\begin{array}{c}\text { Chosen Ratio } \\
\text { for KW } \\
\text { Washed Metal }\end{array}$ & $\begin{array}{l}\text { Chosen Ratio } \\
\text { for KW Above } \\
\text { Water Debris }\end{array}$ \\
\hline Column 1 & Column 2 & Column 3 & Column 4 & Column 5 & Column 6 & Column 7 \\
\hline Tritium & $H-3$ & $0.26 \%$ & $0.26 \%$ & $0.090 \%$ & $0.26 \%$ & $7.1 \%$ \\
\hline Cobalt & $(c 0-60$ & $8.3 \%$ & $0.53 \%$ & $1.0 \%$ & $0.025 \%$ & $3.2 \%$ \\
\hline Nickel & $\mathrm{Ni}-63$ & $0.036 \%$ & $0.036 \%$ & $0.34 \%$ & $0.034 \%$ & $0.26 \%$ \\
\hline Strontium & $\mathrm{Sr}-90$ & $76 \%$ & $105 \%$ & $103 \%$ & $78 \%$ & $10 \%$ \\
\hline Antimony & Sb- 125 & $3.3 \%$ & $0.04 \%$ & $0.16 \%$ & $0.16 \%$ & $0.16 \%$ \\
\hline Cesium & $\mathrm{Cs} / \mathrm{Ba}-137 \mathrm{~m}$ & $100 \%$ & $100 \%$ & $100 \%$ & $100 \%$ & $100 \%$ \\
\hline Promethium & Pm- 147 & $2.3 \%$ & $2.3 \%$ & $2.3 \%$ & $2.0 \%$ & $2.0 \%$ \\
\hline Samarium & $\mathrm{Sm}-151$ & $1.4 \%$ & $1.4 \%$ & $1.4 \%$ & $1.3 \%$ & $1.3 \%$ \\
\hline Europium & Eu- 152 & $0.0067 \%$ & $0.062 \%$ & $0.062 \%$ & $0.0068 \%$ & $0.0068 \%$ \\
\hline Europium & Eu-154 & $2.6 \%$ & $1.4 \%$ & $1.4 \%$ & $0.72 \%$ & $0.72 \%$ \\
\hline Europium & Eu-155 & $1.8 \%$ & $0.45 \%$ & $0.45 \%$ & $0.13 \%$ & $0.13 \%$ \\
\hline Uranium & U-234 & $0.0074 \%$ & $0.0074 \%$ & $0.027 \%$ & $0.0064 \%$ & $0.0075 \%$ \\
\hline Uranium & $\mathrm{U}-235$ & $0.00030 \%$ & $0.00030 \%$ & $0.0046 \%$ & $0.00025 \%$ & $0.0010 \%$ \\
\hline Uranium & $U-238$ & $0.0061 \%$ & $0.0061 \%$ & $0.021 \%$ & $0.0050 \%$ & $0.0062 \%$ \\
\hline Plutonium & $\mathrm{Pu}-238$ & $0.95 \%$ & $1.7 \%$ & $2.1 \%$ & $0.79 \%$ & $0.11 \%$ \\
\hline Plutonium & $\mathrm{Pu}-239$ & $1.9 \%$ & $7.0 \%$ & $13 \%$ & $1.6 \%$ & $0.90 \%$ \\
\hline Plutonium & $\mathrm{Pu}-240$ & $1.0 \%$ & $5.1 \%$ & $5.1 \%$ & $0.87 \%$ & $0.87 \%$ \\
\hline Plutonium & $\mathrm{Pu}-241$ & $50 \%$ & $174 \%$ & $197 \%$ & $47 \%$ & $7.7 \%$ \\
\hline Americium & Am-24I & $8.2 \%$ & $11 \%$ & $17 \%$ & $2.7 \%$ & $0.77 \%$ \\
\hline Curium & C.m-244 & $0.013 \%$ & $0.013 \%$ & $0.013 \%$ & $0.0084 \%$ & $0.0084 \%$ \\
\hline
\end{tabular}

gamma ratio range in Table 2-4, the project will be allowed to default to column 4 (KE Below Water Unwashed or Nonmetal Debris) in Table 2-3 for these waste streams. The reason for this is that column 4 is largely comprised of radionuclide ratios from the basin floor sludge and is a very conservative indicator of 'TRU content. Additional options are discussed in Appendix $\Lambda .1$, Section A.1.3. 
Table 2-4. Designated Ratios and Definition of Anomalous Waste.

\begin{tabular}{|c|c|c|}
\hline $\begin{array}{l}\text { Source of Radionuclide } \\
\text { Ratio/Waste Stream }\end{array}$ & $\begin{array}{c}\text { Estimated Ratio } \\
\text { of Cs-137 to } \\
\text { Sum of Co-60, } \\
\text { Cs-137, Sb-125, } \\
\text { Eu-152,-154, -155 }\end{array}$ & $\begin{array}{l}\text { If Ratio falls outside } \\
\text { the Target Range } \\
\text { Indicated, it is } \\
\text { Considered } \\
\text { Anomalous }\end{array}$ \\
\hline \multicolumn{3}{|c|}{ Below Water } \\
\hline $\begin{array}{l}\text { Table 2-3, Column } 3 \text { for KE Below } \\
\text { Water Washed Metal I)ebris, waste } \\
\text { streams } 11,14 \text { (INNF 2000a) }\end{array}$ & $116 \%$ & $105-125 \%$ \\
\hline $\begin{array}{l}\text { Table 2-3, Column } 4 \text { for KE Non- } \\
\text { metal or Non-washed Below Water } \\
\text { Debris, waste streams } 12,13 \text { (HNF } \\
2000 \text { a) }\end{array}$ & $103 \%$ & $100-110 \%$ \\
\hline $\begin{array}{l}\text { Table } 2-3 \text {, Column } 6 \text { for } \mathrm{KW} \text { Washed } \\
\text { Metal Below Water Debris, waste } \\
\text { streams } 11,12,13,14(\text { HF } 2000 \mathrm{a})\end{array}$ & $103 \%$ & $100-110 \%$ \\
\hline \multicolumn{3}{|c|}{ Above Water } \\
\hline $\begin{array}{l}\text { Table } 2-3 \text {, Column } 5 \text { for KE Above } \\
\text { Water Debris, waste streams } 1-10 \text {, } \\
16-20 \text { (IJNF } 2000 \text { a) }\end{array}$ & $101 \%$ & $100-105 \%$ \\
\hline $\begin{array}{l}\text { Table 2-3, Column } 7 \text { for KW Above } \\
\text { Water Debris, waste streams } 1-10 \text {, } \\
16-20 \text { (lINF } 2000 a)\end{array}$ & $104 \%$ & $100 \ldots 110 \%$ \\
\hline
\end{tabular}

\footnotetext{
See Appendix A, Table A-2 for a discussion of selected ratios and ranges. The target ranges shown are estimated based on the selected ratios and hypothetical gamma spectra. Once actual instruments are obtained and calibrated, the target range may be adjusted to allow for specific detector efficiencies and instrument performance characteristics.
}

\subsubsection{Suspect TRU Waste}

In addition to consideration of the gamma ratios, any waste for which the estimated TRU radionuclide content is greater than $100 \mathrm{nCi} / \mathrm{g}$ total may be subjected to contingency/NDA sampling and a more precise estimate of the TRU content obtained. If a more precise measurement of TRU $J$ content of the waste is obtained, the contingency/NDA sampling results will be used. If a more precise measurenent of the waste are not oblained or confirm that the waste is potentially TRU, alternatives to disposal at ERDF will be explored. 


\subsubsection{Ion-Exchange Modules (Waste Stream 15, HNF 2000a)}

The IXMs will be characterized as described in Section 2.3. Radionuclide content will be estimated from the routine monthly analysis of basin water and the calculation of maximum radionuclide content based on the measured water values and the measured flow rates over the service life of the IXM column. The dose rate to curie conversion approach will not be used on the IXMs.

\subsubsection{Radiological Survey Methods/Quality Control Requirements}

Surveys of the surface of the waste packages will be performed to the criteria discussed in Procedure OP-46-006 to determine if waste packages can be removed from the initial staging area and placed in a bulk waste container. Radiological protection technicians perform surveys and obtain smears from the surfaces of waste packages (typically wrapped or bagged in plastic) to assess compliance with the criteria in Procedure OP-46-006. It is anticipated that due to contamination levels on the waste and the general background in the bagging area, smears of waste package surfaces will be required before removal from the staging area. Appropriate scan speeds, survey techniques, and smear counting procedures are referenced in the instrument specific procedures that will be used (see Section 2.2.6.1).

The dose rate surveys on waste packages used for estimation of cesium-137 curie content (and subsequent estimate of other radionuclides) will be performed according to SNF-OPS-DI, "Perform Dose to Curie Calculations" (HNF procedure in preparation based on WHC-SD-WM-PROC-020). Data will be reported to appropriate K Basin staff on a Radiological Survey Report form in the procedure.

2.2.6.1 Radiological Surveys. Radiological surveys of the outside of waste packages for radiological control purposes and to comply with ERDF waste surface contamination acceptance criteria will be performed and reported per:

- OP-46-006

- HNF-PRO-1892

The instruments used will be per procedures:

- Beta/gamma survey meter, "GM Portable Survey Instrument," HNF-PRO-632

- Dose rate meter, "Eberline RO-3B (CP)," HNF-PRO-648

- Alpha survey meter, "Portable Alpha Meter," HNF-PRO-633 
Radiological surveys performed to measure gamma dose rate for subsequent estimation of cesium-137 content and surveys performed to determine whether waste is anomalous, will be performed per procedures:

- Dose Rate Meter, WHC-SD-WM-PROC-020 (to be revised as HNF-specific procedure)

- Multi-channel Gamma Survey Meter, such as Eberline 2221 with NaI detector (HNF procedure to be written)

2.2.6.2 Quality Control Requirements for Radiological Surveys. This characterization effort relies heavily on field measurements to extrapolate current estimated radionuclide ratios based on past laboratory and NDA analyses to waste in the $\mathrm{KE}$ and $\mathrm{KW}$ Basin areas. Quality assurance is necessarily built into each phase of the characterization as field instrument operational checks that monitor field instrumentation performance.

Alpha, beta/gamma surveys, gamma surveys and dose rate measurements will be used. Instruments will be calibrated against known standards representative of the instrument response to the identified analyte. The instrument will be within the calibration period specified by the instrument procedure.

Quality control measures taken to support field operations performance, including daily calibration checks, which will be performed and documented on each instrument used to survey or characterize waste. These checks will be performed as defined in the appropriate instrument procedure.

2.2.6.3 Instrument Testing, Inspection, and Maintenance Requirements. Measurement and testing equipment used in the field will be subject to acceptance testing and preventative maintenance measures to ensure minimization of measurement system downtime. Maintenance requirements, such as parts lists and instructions, and documentation of routine maintenance, will be performed according to the general program procedure ("Radiation Protection Instrument Program," HNF-PRO-436), as well as any additional measures that are specified in the specific instrument procedure referenced in Section 2.2.6.1.

2.2.6.4 Instrument Calibration and Frequency. Instruments used for surveys and screening for off-site sample shipment will be calibrated in accordance with HNF-PRO-436. The results from all instrument calibration activities shall be recorded as defined in the program procedure. Control documents must specify when the instrument was last calibrated, the results of that calibration, and the due date for new calibration.

2.2.6.5 Inspection/Acceptance Requirements for Supplies and Consumables. Procurement activities related to radiological survey will be limited to performing acceptance testing for all instruments and standards used as described in the program procedure HNF-PRO-436 and specific instrument procedures. 
2.2.6.6 Field Survey Documentation. Field documentation will be kept in accordance with HNF-PRO-1892. Data used to characterize waste radionuclide content will be recorded as described in the procedure for categorizing and inventorying waste in standard containers (SNF-OPE-DI-005) or equivalent.

\subsubsection{Waste Handling and Custody Requirements}

All waste handling, shipping, and custody requirements will be met in accordance with Procedure OP-46-006, "Processing Contaminated Waste for ERDF Disposal."

In addition, radioactive waste will be surveyed for shipment in accordance with HNF-PRO-1892. Radiological survey tags will be attached to individual bags of waste until they are placed in a larger container, such as a barrel or box. The survey tags from bags that go into a larger container will be retained in order to provide a record of the surveys and associated estimate of curie content of the waste.

\subsubsection{Waste and Sample Shipping}

Waste and sample packaging for shipping will be performed in accordance with procedure OP-46-006, "Processing Contaminated Waste for ERDF Disposal." The samples or waste will be shipped per the procedure HNF-PRO-157, "Radioactive Material/Waste Shipments."

The current process is that for samples shipped to onsite laboratories, unused samples are sent back to the generator. For samples shipped offsite, unused samples are not returned. The contracts with offsite laboratories specify that the laboratory disposes of any remaining sample and the waste associated with analysis.

\subsection{K BASIN WATER SAMPLING FOR IXM WASTE DESIGNATION}

Currently process control samples are collected weekly from the KE and KW Basins per procedures OP-43-005E, Rev 3D, Collect Routine Water Samples at 105-KE and OP-43-006W, Rev 4C, Collect Routine Water Samples at 105-KW. The samples are analyzed at the SNF Operations Counting Facility for cesium-137 and total alpha. Samples are taken to detect changes in the water quality, and to maintain efficiency of the various filtration units. Data obtained are used to determine the cesium-137 removal efficiency and TRU inventory of the IXM so that the unit can be removed from service before the IX resin is depleted or the TRU limit is reached. The referenced weekly process control sample procedures are not part of the scope of this SAP.

There are two separate and distinct basin water treatment systems in place that use IXMs. One system is the skimmer system, which takes water near the surface of the basin. This system has been in service for many years and there is existing process knowledge. This is IXM Position No. 4. The other system is the new IWTS, which takes water near the canister decapping station, washing machine, and dump table. These are IXMs Positions 1, 2, and 3. A unique sampling 
plan will be performed during Phase 3 startup testing in the basin to develop a sampling strategy for IXM Positions 1, 2, and 3. The approach that is discussed in this SAP is specifically directed at the IXM in position 4, but it is anticipated that a similar approach may be used for the IWTS IXMs in positions 1,2 , and 3.

\subsubsection{Sample Requirements}

Samples are collected monthly from the center of the $\mathrm{KE}$ and $\mathrm{KW}$ Basins per procedure OP-43-028, Rev 0D, Collect Monthly Center of Basin Water Samples and are analyzed at the 222-S Laboratory in accordance with Letter of Instruction 2000-SM-LOI-002 (Jochen 2000). Other analytical laboratories may be used when an appropriate Letter of Instruction is in place. These monthly samples are collected for additional radiochemical analyses required for waste characterization to ensure compliance with Process Standard 400 . The samples are analyzed for gamma emitters (e.g., cesium-137, cobalt-60), as well as plutonium-238, plutonium-239/240, uranium, tritium and strontium-90. The results from these samples will be used to estimate radiochemical loading of the IXMs for waste characterization purposes. Based on the analytical results for a limited set of COCs, and estimated radionuclide ratios which relate the COCs that are not measured to those that are, the average concentration of the radionuclides in basin water is estimated for the time period that the IXMs were in service. Using the measured or design flow rates and length of service that are available through procedures provided, an estimated radionuclide content of the IXMs is calculated.

\subsubsection{Water Sample Handling and Custody Requirements}

Sample handling, shipping and chain-of-custody requirements will be performed in accordance with the following procedures:

- OP-43-028, Rev 0D, "Collect Monthly Center of Basin Water Samples"

- OP-43-030, Rev 0B, "Transport Water Samples to 222-S Lab."

\subsubsection{Water Sample Preservation, Containers and Holding Times}

Samples of liquids require acidification to $\mathrm{pH}$ of 2 for preservation for metal and radiological analysis. Containers are specified in sampling procedure OP-43-028. Addition of acid to the sample bottles is not currently part of the monthly water sampling procedure. The procedure will be modified to allow for acidification of the samples either prior to sampling or at the SNF operations counting facility. The holding times for radionuclide analyses and metals is 180 days. 


\subsubsection{Water Sample Shipping}

All sample containers will undergo field radiological screening to determine proper shipping and handling requirements. In addition, the samples will be sent to the SNI counting facility for radiological screening prior to shipping. On-site transfers over nonpublic thoroughfares will be performed in accordance with written procedures (OP-43-029, OP-43-030). The procedures include requirements for proper monitoring and control of the radioactive samples and should be reviewed and approved by the Radiological Control Organization. Shipments of water samples over public thoroughfares are performed per HNl--I'RO- 157 for radioactive water samples.

\subsubsection{Analytical Methods Requirements for Water Samples}

Fixed analytical laboratory parameters for water analysis are listed in Table 2-5. Laboratoryspecific Standard Operating Procedures (SOPs) for analytical methods are in place. Laboratory SOPs and QA Plans to be used include Analytical Procedures and QA Plans from 222-S Laboratory or equivalent procedures from other analytical laboratories. Changes or additional methods identified during future engineering or planning will be presented in page changes, addenda, or revisions to this SAP as appropriate. Detection limits achievable by the laboratory will be dependent on sample quantity available and may also be affected by the matrix and radionuclide activity levels of the sample.

Table 2-5. Water Sample Measurement Methods, Detection Limits, and Minimum Sample Volumes for Selected Radionuclide COCs. (2 pages)

\begin{tabular}{|c|c|c|c|c|c|}
\hline \multirow{3}{*}{$\begin{array}{l}\text { Contaminant of } \\
\text { Concern (COC) }\end{array}$} & \multirow{3}{*}{$\begin{array}{l}\text { Analytical } \\
\text { Callout }\end{array}$} & \multirow{3}{*}{$\begin{array}{l}\text { Analytical } \\
\text { Technique }\end{array}$} & \multirow{3}{*}{$\begin{array}{c}\text { Method } \\
\text { Reference* }^{*}\end{array}$} & \multicolumn{2}{|c|}{ 222-S Laboratory } \\
\hline & & & & Detection Limits & $\begin{array}{c}\text { Volume } \\
\text { Requirements }\end{array}$ \\
\hline & & & & $\begin{array}{l}\text { Liquid } \\
\text { (pCi/L) }\end{array}$ & $\begin{array}{l}\text { Liquid } \\
\text { (L) }\end{array}$ \\
\hline \multicolumn{6}{|c|}{ Radionuclides } \\
\hline Pu-238, l'u-239/240 & Pu Isutopic & $\begin{array}{l}\text { Alpha Energy } \\
\text { Aralysis }\end{array}$ & $1 . \wedge-953-104$ & 1 & 2 \\
\hline$A m-241$ & Am Isotopic & $\begin{array}{l}\text { Alpha lanergy } \\
\text { Analysis }\end{array}$ & $1 . \wedge-953-104$ & 1 & 2 \\
\hline$(0)-60$ & (i): $\Lambda$ & $\begin{array}{l}\text { Gimma finergy } \\
\text { Analysis }\end{array}$ & $|A-548-12|$ & 40 & 2 \\
\hline sb-125 & Gilis & $\begin{array}{l}\text { (iammal linergy } \\
\text { Analysis }\end{array}$ & $1 . \Lambda-548-121$ & 40 & 2 \\
\hline$(s-134$ & (itis & $\begin{array}{l}\text { (iamma linergy } \\
\text { Analysis }\end{array}$ & $1 . \wedge-548-12 I$ & 40) & 2 \\
\hline$(s-137$ & Git:A & $\begin{array}{l}\text { (iamna Lnergy } \\
\text { Analysis }\end{array}$ & $1 . \Lambda-548-121$ & 40 & 2 \\
\hline $1 \mathrm{u}-152$ & (il: $\Lambda$ & $\begin{array}{l}\text { (iamnlia linergy } \\
\text { Analysis }\end{array}$ & I. $\wedge-548-121$ & 40) & 2 \\
\hline $\operatorname{lu}-154$ & Gil $\Lambda$ & $\begin{array}{l}\text { Gamma linergy } \\
\text { Analysis }\end{array}$ & I.A-548-121 & 40 & 2 \\
\hline
\end{tabular}


Table 2-5. Water Sample Measurement Methods, Detection Limits, and Minimum Sample Volumes for Sclected Radionuclide COCs. (2 pages)

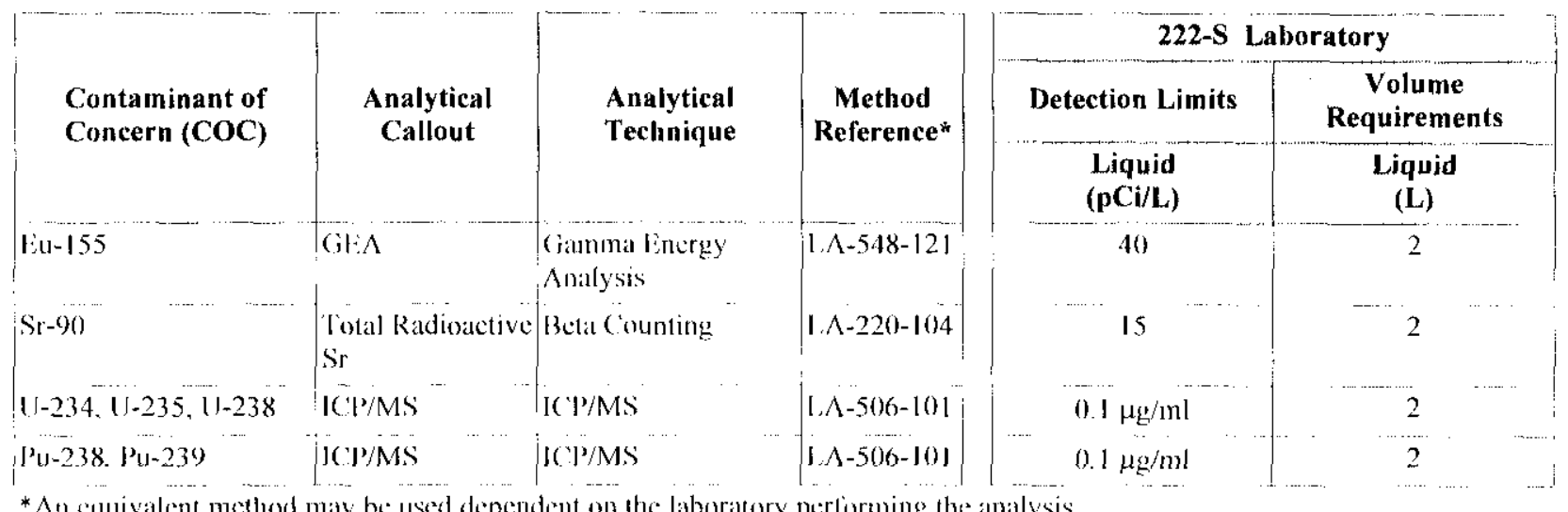

\subsubsection{Laboratory Quality Control Requirements for Water Samples}

Monthly center-of-basin water samples are collected via a proportional sampler. Field duplicates are not collected.

Equipment rinsate blanks are not used for basin water sampling as bottles for collection of water are used once and disposed after analyses and no other equipment is used during water sampling.

Control measures taken to monitor laboratory performance are:

- One laboratory method blank for every 20 samples (5\% of samples), analytical batch or sample delivery group (whichever is most frequent) will be carried through the complete sample preparation and analytical procedure. The method blank will be used to document contamination resulting from the analytical process.

- One laboratory control sample or blank spike will be performed for every bateh of samples for each analytical method criteria to monitor the effectiveness of the sample preparation process. The results from the analyses are used to assess laboratory performance.

- A matrix spike sample will be prepared and analyzed for every 20 samples (as applicable to method) of the same matrix or sample preparation batch, whichever is most frequent. The matrix spike results are used to document the bias of an analytical process in a given matrix.

- I aboratory duplicates or matrix spike duplicates will be used to assess precision and will be analyzed at the same frequency as the matrix spikes. 


\subsubsection{Instrument/Equipment Testing, Inspection, and Maintenance}

Measurement and testing equipment used in the field or in the laboratory that directly affects the quality of analytical data will be subject to preventative maintenance measures that ensure minimization of measurement system downtime and avoids inconsistencies in instrument performance.

Laboratories and onsite measurement organizations must maintain their equipment. Instrument preventative maintenance consists of routine inspections, instrument maintenance, and corrective actions. Preventative maintenance is performed in accordance with a schedule based on manufacturer's recommendations, instrument performance history, and usage. Each instrument has a logbook to record maintenance events with date and name of person performing the maintenance. The logbook includes routine inspections, significant corrective actions, instrument maintenance and repairs.

Spare parts inventories help ensure minimal loss of analytical capability. Spare parts include day-to-day consumables and manufactures recommended spare parts.

\subsubsection{Instrument Calibration and Frequency}

Laboratory measurement systems are subject to calibration and/or calibration verification before use for sample analyses. Calibrations are conducted in accordance with the specific analytical methods performed and in the applicable laboratory QA Plan.

Instruments that fail acceptance criteria shall be investigated and re-calibrated. Instruments are not allowed to be used for sample analysis until they meet acceptance criteria. The responsible chemist or manager is required to take corrective action when measurement systems fail calibration QC criteria.

The minimum requirements of calibration, frequency, and acceptance criteria for radionuclide analyses presented in the tables listed below, which can be found in Section 7.4.1 of the 222-S Laboratory QA Plan (HNF-SD-CP-QAPP-016, Markel 2000).

- Table 7-1. Minimum Requirements of Calibration, Background, and Counter Control for Alpha and Beta Counting (pages 7-7, 7-8)

- Table 7-2. Minimum Requirements of Calibration, Background, and Counter Control for Gamma Spectrometry (page 7-9)

- Table 7-3. Minimum Requirements of Calibration, Background, and Counter Control for Alpha Spectrometry (pages 7-10, 7-11)

- Table 7-4. Minimum Requirements of Calibration, Background, and Counter Control for Beta Spectrometry (pages 7-12, 7-13) 
If other laboratories are contracted, performance shall be equivalent.

\subsubsection{Inspection/Acceptance Requirements for Supplies and Consumables}

The quality of reagent water is monitored by a resistivity check, assessments of sample blank data, and monthly analysis performed by ion chromatography and ICP. Reagent water checks are described more fully in laboratory procedures or the laboratory QA Plan.

Percent purity levels of gases or reagents necessary for quality analysis are listed in each analytical procedure. The quality of gases or reagents is monitored by performance of the preparation blank.

Standards that are prepared and used for the first time are verified against existing working standards or against an independent source to ensure accuracy of the standard.

The Standards Laboratory maintains records that provide traceability of the prepared standards to original standard reference materials.

Radioactive material standards are verified by preparing and counting mounts. The results of the count are compared to the calculated certified value.

\subsection{CONTINGENCY ANALYSES}

The purpose of contingency sampling and analysis or NDA is to verify radionuclide ratios. The purpose of verifying the radionuclide ratios may be to demonstrate that a waste is or is not anomalous. Contingency sampling may also be used if the waste is determined to be suspect TRU waste (dose to curie estimates indicate greater than $100 \mathrm{nCi} / \mathrm{g}$ TRU). Determination of anomalous waste is discussed in Section 2.2.3.

\subsubsection{When Contingency Analyses/Nondestructive Assay will be Required}

Contingency analysis or NDA may be required if the measured gamma ratios fall outside of the target range of Table 2-4 and the waste is determined to be anomalous as discussed in Section 2.2.3. Contingency analysis could also occur if the waste is designated as potential TRU waste utilizing the dose to curie conversion factors previously discussed. Before conducting contingency sampling, $\mathrm{K}$ Basin project staff will determine if there are cost-effective alternatives. If contingency sampling or NDA is chosen, then a specific work plan for sampling or performing NDA will be developed. Sections 2.4.2 through 2.4.9 discuss the anticipated approach to contingency sampling and analysis. Section 2.4 .10 discusses the anticipated approach to contingency NDA. The details of the approach may vary depending on the selected vendor and specific waste to be sampled. Before conducting a contingency sampling effort, representatives from ERDF would be consulted to ensure that the proposed process would provide acceptable data for waste designation. 


\subsubsection{Contingency Sample Locations, Handling and Custody Requirements}

Waste that has been determined to require sampling will be staged in a controlled area while a work plan is written to sample the waste and a contract is put in place for the analyses. If contingency sampling is required, it will occur on a representative sample of the waste in the package that is being sampled. The purpose of the contingency sampling is to determine the appropriate representative radionuclide ratios to cesium-137 through radiochemical analysis. It is recommended that beta/gamma and/or alpha survey instruments be used to select a piece of the waste that exhibits a relatively high count rate. This will ensure that adequate contamination is available so the analyses will not be reported as "less-than values."

$\mathrm{K}$ Basin operators will be responsible for sample collection, packaging and shipment of samples to 222-S Laboratory, WSCF, or other private laboratory. Before sampling, procedures will be written as part of a work package or work plan. The work package will include a detailed description (or reference an existing procedure) of the following activities:

- Sample Identification

- Chain of Custody

- Sample Packaging

- Sample Shipment

- Field Logbooks

Procedures shall be written in accordance with the guidance presented in HASQARD, Volume II, Section 4.0.

\subsubsection{Contingency Sample Preservation, Containers, Size, and Holding Times}

Sample preservation is not applicable to these debris samples. Certified clean plastic or glass containers are not necessary for sample collection. Any clean container that is appropriate and available may be used. It is recommended that at least $200 \mathrm{~g}$ of sample be collected in two or more bottles. This will provide a backup sample if needed. The laboratory requires that the waste be cut into pieces of $1-2$ in $^{2}$ each or less. It is recommended that final sample weight is discussed with the laboratory before obtaining the samples. Holding times for radionuclide analyses are 180 days. 


\subsubsection{Contingency Sample Shipping}

All sample containers will undergo field radiological screening to determine proper shipping and handling requirements. On-site transfers over nonpublic thoroughfares shall be performed in accordance with written procedures. The procedure includes requirements for proper monitoring and control of the radioactive samples and should be reviewed and approved by the Radiological Control Organization. Shipments of waste samples are performed per HNF-PRO-156, "Non-radioactive Hazardous Material/Hazardous Waste Shipments (HM/HW)," if the waste is known or suspected to be mixed waste samples, and HNF-PRO-157 for radioactive waste samples.

\subsubsection{Analytical Methods Requirements for Contingency Samples}

Fixed analytical laboratory parameters and methods for contingency samples are listed in Table 2-6. Laboratory-specific SOPs for analytical methods are in place. Laboratory SOPs and QA Plans to be used include Analytical Procedures and QA Plans from 222-S Laboratory. Other laboratories may be used. Changes or additional methods identified during future engineering or planning will be presented in page changes, addenda, or revisions to this SAP as appropriate. Detection limits achievable by the laboratory will be dependent on sample quantity available and may also be affected by the matrix and radionuclide activity levels of the sample.

\subsubsection{Quality Control Requirements for Contingency Samples}

This characterization effort relies on direct measurements to locate areas of higher beta/gamma contamination for subsampling requirements. Quality assurance is necessarily built into each phase of the characterization both as QC samples, which monitor sampling and laboratory performance, and field instrument operational checks that monitor field instrumentation performance.

Quality control measures taken to support field operations performance are described in Section 2.2.6.

For contingency samples collected to support fixed laboratory analyses, the following QC samples will be collected during sampling and sent to the laboratory.

- Equipment blanks will be collected on contingency samples to assess the potential for gross cross contamination of the sampling equipment, the effectiveness of the sample decontamination process, and potential sampling environment contaminant contribution. 
Table 2-6. Contingency Sample Measurement Methods, Detection Limits, and Sample Volumes for Selected Radionuclide COCs.

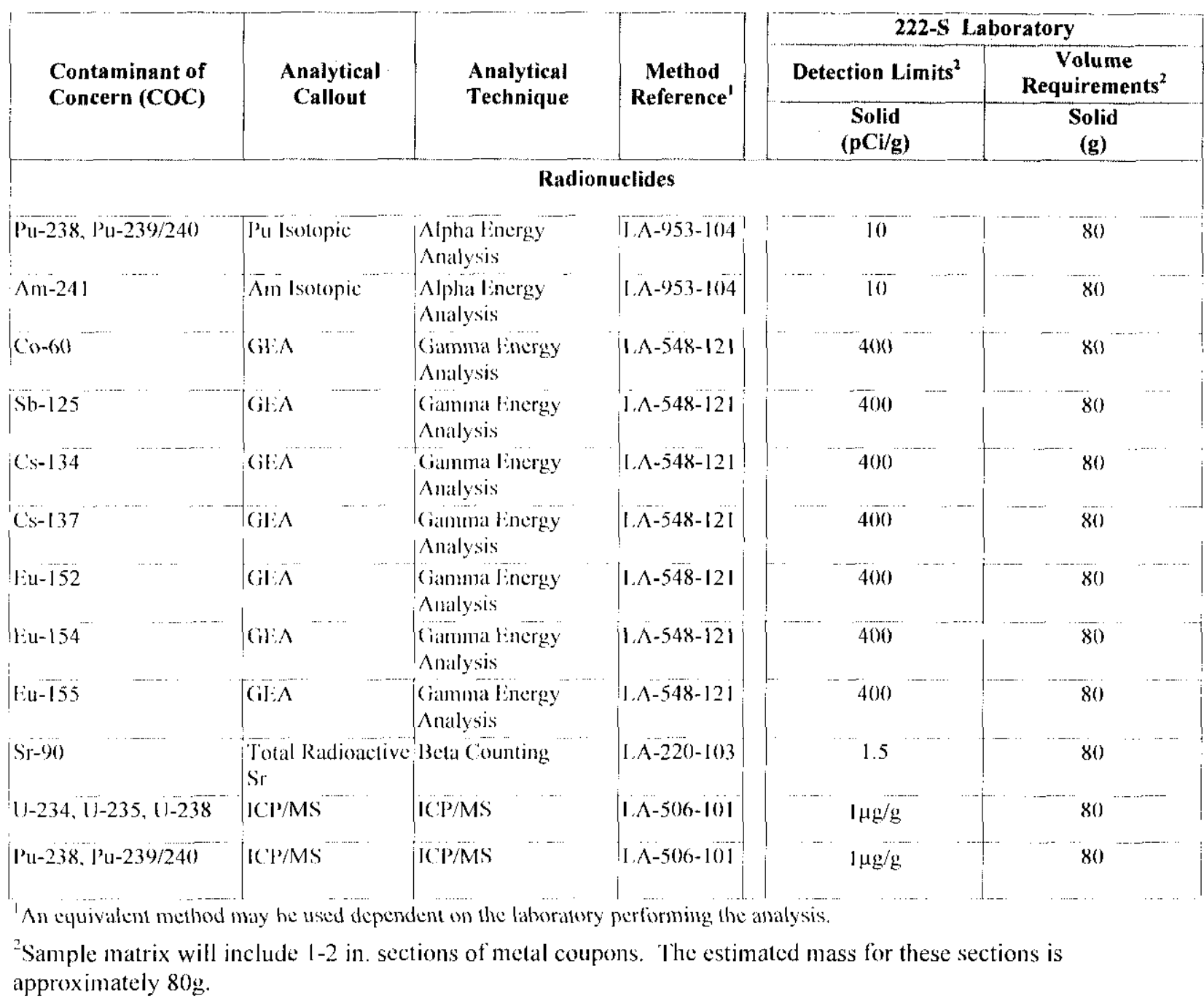

Control measures taken to monitor laboratory performance are:

- Onc laboratory method blank for every 20 samples (5\% of samples), analytical batch or sample delivery group (whichever is most frequent) will be carried through the complete sample preparation and analytical procedure. The method blank will be used to document contamination resulting from the analytical process.

- One laboratory control sample or blank spike will be performed for every batch of samples for each analytical method criteria to monitor the effectiveness of the sample preparation process. The results from the analyses are used to assess laboratory performance. 
- A matrix spike sample will be prepared and analyzed for every 20 samples (as applicable to method) of the same matrix or sample preparation batch, whichever is most frequent. The matrix spike results are used to document the bias of an analytical process in a given matrix. It is assumed the matrix spike will be added after digestion.

- Laboratory duplicates or matrix spike duplicates will be used to assess precision and will be analyzed at the same frequency as the matrix spikes. Replicate analysis of the etching solution (digestate) of pipe coupons will be used to monitor precision where appropriate.

\subsubsection{Instrument/Equipment Testing, Inspection, and Maintenance}

See Section 2.3.7 for applicable criteria.

\subsubsection{Instrument Calibration and Frequency}

See Section 2.3.8 for applicable criteria.

\subsubsection{Inspection/Acceptance Requirements for Supplies and Consumables}

See Section 2.3.9 for applicable criteria.

\subsubsection{Nondestructive Assay}

Contingency NDA may be performed on waste that has been determined to be anomalous or suspect TRU. The K Basin Project staff will determine the efficacy of performing NDA on waste after consideration of disposal options, cost and schedule.

A primary purpose of the contingency NDA is to determine more accurately the gamma-emitting radionuclide mix of the waste. In addition, the NDA may employ neutron-counting instrumentation in order to obtain a more direct estimate of the TRU content of the waste. The NDA determination of gamma and/or neutron-emitting radionuclides will be on the entire waste package.

Waste that has been identified as anomalous will be staged in a controlled area while an NDA vendor is contacted. For NDA determination of radionuclide content of the waste, the vendor will supply collimated detector systems that are capable of identifying and quantifying gamma and neutron-emitting radionuclides in the waste. Before use, the vendor will supply $\mathrm{FH}$ with operational procedures, calibration procedures, estimated detection levels and assurances that the detection levels quoted can be met in the general background radiation fields present from the waste and surrounding areas. The vendor's procedures will be compliant with standard industry methods as described in NUREG/CR-5550, Passive Nondestructive Assay of Nuclear Materials (NRC 1991) and ANSI N42.14, Calibration and Use of Germanium Spectrometers for Measurement of Gamma-Ray Emission Rates of Radionuclides (ANSI 1991), as appropriate. 


\subsection{ASSESSMENT/OVERSIGHT FOR SURVEY SAMPLING AND ANALYSIS}

Quality assurance oversight requirements are described below.

\subsubsection{Assessments and Response Actions}

$\mathrm{K}$ Basin QA may conduct random surveillances and assessments in accordance with QA-11-006-02 "Quality Assurance Surveillances" to verify compliance with requirements outlined in this sampling and analysis plan, project work packages, procedures, and regulatory requirements.

Deficiencies identified during the assessment will be reported in accordance with QA-11-006-02. When necessary, corrective actions will be taken by Operations Support Manager.

\subsubsection{Reports to Management}

Management Assessments are performed in accordance with MS-1-036-02, "Management Assessments." Management Assessment results are reviewed and analyzed by management to identify and implement appropriate actions. Management Assessment results are distributed to affected managers and deficiencies and are managed as required by HNF-PRO-052, "Corrective Action Management."

\subsection{DATA REVIEW, VALIDATION AND USABILITY}

Requirements for review and evaluation of data usability are described in the following sections.

\subsubsection{Data Review and Verification Requirements}

Data verification will be performed on analytical data sets to assure that sampling and chain-ofcustody documentation is complete, sample numbers can be tied to the specific sampling location, samples were analyzed within the required holding times, and analyses meet the data quality requirements specified in the characterization plan.

Analytical personnel and the project team will review the data. Laboratory personnel will perform a peer review of all analytical data. Peer review will be conducted by a person trained to the particular analytical method being reviewed. HASQARD, Volume 4 (DOE-RL 1998) describes the data review that will be performed by the laboratory. The laboratory will use its own data review procedures that meet the HASQARD criteria to review data before it is sent to the K Basin Project.

Project personnel or their designee will review the data and the summary QC with respect to the criteria in this SAP. 
Survey measurement systems will be verified by a review of $5 \%$ of the documentation to ensure that calibration checks are performed per the methods, dates of survey, and analysis locations are properly documented. The review should be performed by program personnel.

\subsubsection{Data Validation}

Analytical and survey data will not undergo a formal validation.

\subsubsection{Reconciliation With User Requirements}

Following review, the laboratory data will be assessed by the project team against the criteria in Tables 2-1, 2-5, and 2-6. Assessment will include review of quantitative DQOs (e.g., accuracy, precision, completeness, and detection limits) and the preparation of a summary report. The final report will include an evaluation of the overall adequacy of the total measurement system with regard to the DQO of the data generated. These quantitative DQOs are defined below.

\section{$\underline{\text { Precision }}$}

If calculated from duplicate measurements:

$$
R P D=\frac{\left(C_{1}-C_{2}\right) \times 100}{\left(C_{1}+C_{2}\right) / 2}
$$

where:

$$
\begin{array}{lll}
\mathrm{RPD} & = & \text { relative percent difference } \\
\mathrm{C}_{1}= & \text { larger of the two observed values } \\
\mathrm{C}_{2}= & \text { smaller of the two observed values }
\end{array}
$$

If calculated from three or more replicates, use RSD rather than RPD:

where:

$$
R S D=(s / \bar{y}) \times 100
$$

$$
\begin{array}{lll}
\mathrm{RSD} & = & \text { relative standard deviation } \\
\mathrm{S} & = & \text { standard deviation } \\
\bar{y} & = & \text { mean of replicate analyses. }
\end{array}
$$


Standard deviation, $\mathrm{s}$, is defined as follows:

where:

$$
s=\sqrt{\sum_{i=1}^{n} \frac{\left(y_{i}-\bar{y}\right)^{2}}{n-1}}
$$

$$
\begin{array}{lll}
\mathrm{s} & = & \text { standard deviation } \\
\mathrm{y}_{\mathrm{I}} & = & \text { measured value of the } \mathrm{i}^{\text {th }} \text { replicate } \\
\bar{y} & = & \text { mean of replicate measurements } \\
\mathrm{n} & = & \text { number of replicates. }
\end{array}
$$

\section{Accuracy}

For measurements where matrix spikes are used:

where:

$$
\% R=100 x\left[\frac{S-U}{C_{s u}}\right]
$$

$$
\begin{array}{lll}
\% \mathrm{R} & = & \text { percent recovery } \\
\mathrm{S} & = & \text { measured concentration in spiked aliquot } \\
\mathrm{U} & = & \text { measured concentration in unspiked aliquot } \\
\mathrm{C}_{\mathrm{sa}} & = & \text { actual concentration of spike added. }
\end{array}
$$

For situations where a standard reference material (SRM) is used instead of or in addition to matrix spikes:

$$
\% R=100\left[\frac{C_{m}}{C_{s r m}}\right]
$$

where:

$$
\begin{array}{lll}
\% \mathrm{R} & = & \text { percent recovery } \\
\mathrm{C}_{\mathrm{m}} & = & \text { measured concentration of SRM } \\
\mathrm{C}_{\mathrm{srm}} & = & \text { actual concentration of SRM. }
\end{array}
$$




\section{Completeness}

Defined as follows for all measurements:

$$
\% C=100 x\left[\frac{V}{T}\right]
$$

where:

$$
\begin{array}{rll}
\% \mathrm{C} & = & \text { percent completeness } \\
\mathrm{V} & = & \text { number of measurements judged valid } \\
\mathrm{T} & = & \text { total number of measurements. }
\end{array}
$$

\section{$\underline{\text { Detection Limit }}$}

Defined as follows for metals measurements:

$$
M D L=t_{(n-1,1-\alpha=0.99)} x S
$$

where:

$$
\begin{array}{lll}
\text { MDL } & = & \text { method detection limit } \\
\mathrm{S} & = & \text { standard deviation of the replicate analyses } \\
t_{(\mathrm{n}-1,1-\alpha=0.99)} & = & \text { students' } \mathrm{t} \text {-value appropriate to a } 99 \% \text { confidence level } \\
& & \text { and a standard deviation estimate with } n-1 \text { degree of freedom }
\end{array}
$$

\subsection{DATA QUALITY ASSESSMENT}

Data quality assessment is performed by the project or project designee, after data review of the survey and standard fixed laboratory data per Section 2.6. The review by the Project or project designee must include evaluation of the method accuracy, precision, detection limits and completeness as required in Sections 2.1.4, 2.2.6, 2.4.5, 2.4.6, and 3.3.

Review the project DQOs. This includes the conceptual model and any assumptions that are included in the data collection design. Because data collection for this project is not determined by a statistical design, hypotheses and error tolerances will not be included in the original DQOs. However, qualitative assessment of both the fixed laboratory data and the survey data can be performed, implementing the procedures outlined below.

No statistical data quality assessment will be performed because (1) no random sampling is conducted, (2) only one sample and duplicate (if composite sample volume is adequate) will be collected for water, and (3) few samples from the same material will be collected for contingency analysis. 
The estimated concentrations of radionuclides will be compared by the project to the applicable ERDF WAC (BHI 1998) for designation.

\subsection{ANALYTICAL DATA REPORTS}

The type of data report required by this SAP is a summary report with QA review. This report includes a case narrative and analytical QC, such as percent recovery on laboratory control sample, matrix spikes, relative percent differences (RPDs) on duplicate or matrix spike/matrix spike duplicates and method blank results. 


\subsection{FIELD RADIOLOGICAL SURVEY AND SAMPLING OBJECTIVES}

\subsection{RADIOLOGICAL SURVEY OBJECTIVES}

This section builds on the DQO Process developed previously (HNF 2000a) and summarized in Section 1.0. The sections below summarize the radiological survey and sample design discussed in previous sections. The project objective is to remove all of the debris (e.g., pipe hangers, fuel storage canisters, miscellaneous tools, hoses) from the $\mathrm{KE}$ and $\mathrm{KW}$ Basins. The material removed will be washed to remove adhering sludge and disposed as waste debris. Waste from above the basin water line (e.g., protective clothing, cloth, light metal, concrete, ceramic, brick) will also be generated. As discussed in Section 2.2, radiological survey of the waste will be used as the primary tool to characterize the waste for disposal.

The objective of radiological survey is to characterize the waste with regard to radioactive COCs. The concentrations of COC radionuclide Cs- 137 will be calculated from the measured dose rate and estimated Cs-137 content, assuming cesium-137 as the primary gamma isotope. As the waste is packaged, approximately $10 \%$ of the packages will be periodically surveyed using a gamma detector capable of measuring two or more portions of the gamma energy spectrum (Section 2.2.3). Anomalous waste is defined as waste that exhibits a ratio of all gamma-emitting radionuclides to the cesium-137 activity that is outside of preset limits (see Table 2-4). If the waste is determined to be anomalous or is estimated to contain TRU at 100 $\mathrm{nCi} / \mathrm{g}$ or more, it may be subjected to contingency NDA and/or sampling as discussed in Section 2.4 to more accurately determine the correct radionuclide mix to apply to the waste.

The objectives of the radiological survey are to:

- estimate the inventory of radionuclides for onsite disposal of the debris,

- identify and prevent disposal of prohibited waste as defined by the ERDF WAC (BHI 1998).

\subsection{SURVEY LOCATIONS AND FREQUENCY}

All waste will be surveyed for dose rates for the purpose of estimating the cesium-137 radionuclide content of the waste. Some of the waste may be surveyed for surface contamination as discussed in procedure OP-46-006 for purposes of designating the waste as NRCW or RCW.

Dose rate meter survey locations for purposes of obtaining an estimate of the cesium- 137 content of the waste will be performed as directed in the appropriate procedure (WHC 1996g, 1997b, SNF-OPS-DI-005). The survey will occur on each designated package of waste and consists of 6 to fourteen measurements at predetermined locations. The measurements will occur in a relatively low background area so as to allow a minimum detectable net dose rate of $0.5 \mathrm{mrem} / \mathrm{hr}$ on each measurement. 
Periodic gamma surveys will be performed as discussed in Section 2.2.3 in a low background area and will be performed on the entire waste package selected. It is anticipated that for every 100 bags of waste that are removed from the basin, 10 randomly-picked bags will be subjected to gamma survey.

\subsection{RADIOLOGICAL SURVEY QUALITY CONTROL}

Radiological survey QC will consist of initial calibrations and operational checks in accordance with the applicable procedures discussed in Section 2.2.6.1.

\subsection{RADIOLOGICAL SAMPLING OBJECTIVES AND REQUIREMENTS}

The objective of radiological contingency sampling for this project are to provide data to confirm (or establish appropriate) radionuclide ratios for anomalous waste as discussed in Section 2.2.3 (Anomalous Waste). Contingency sampling may also be employed to more accurately characterize suspect TRU waste as discussed in Section 2.4.1.

The objective of the water sampling, as discussed in Section 2.3, is to provide data for use in characterizing IXMs that have been taken out of service. 


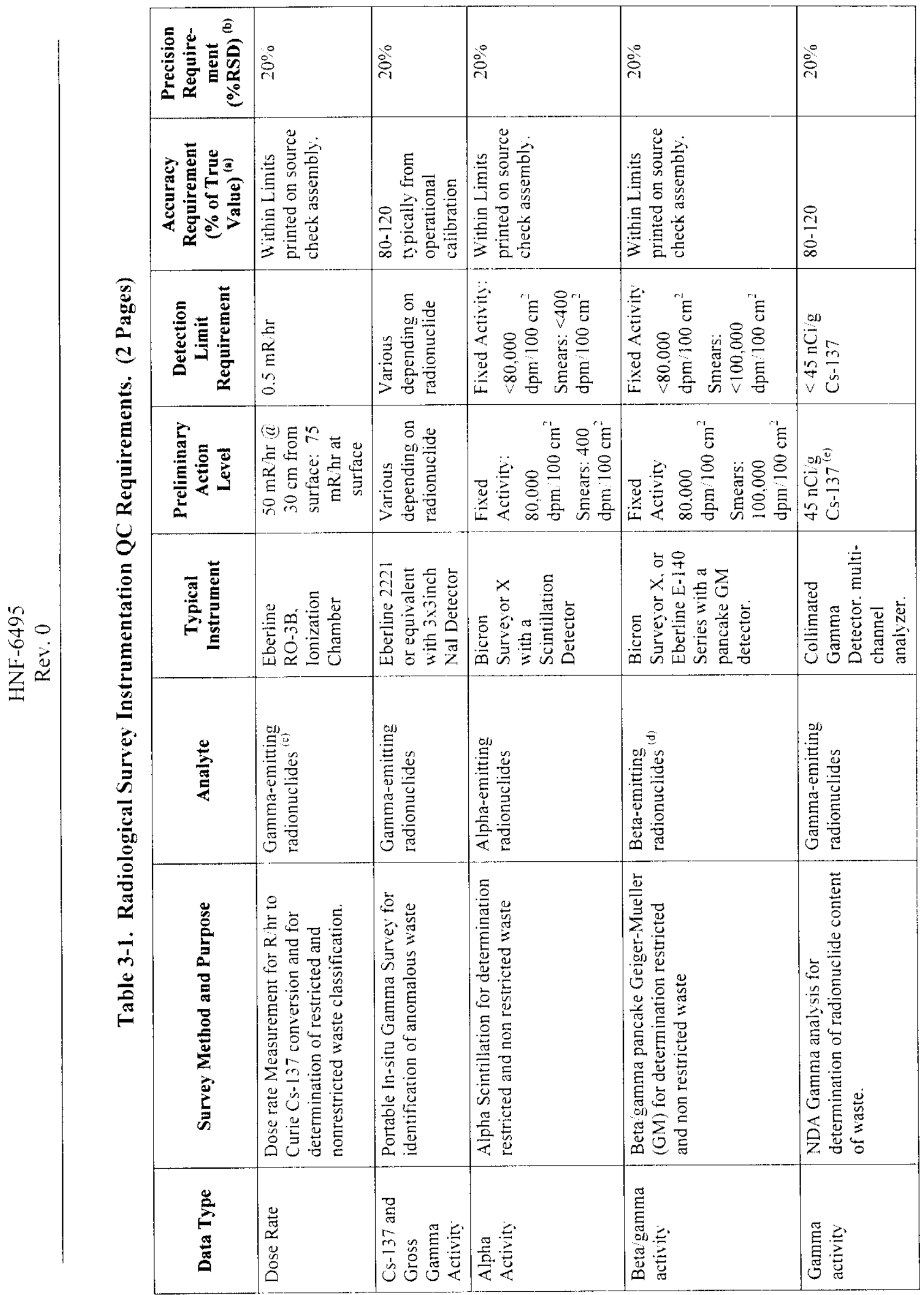

in 


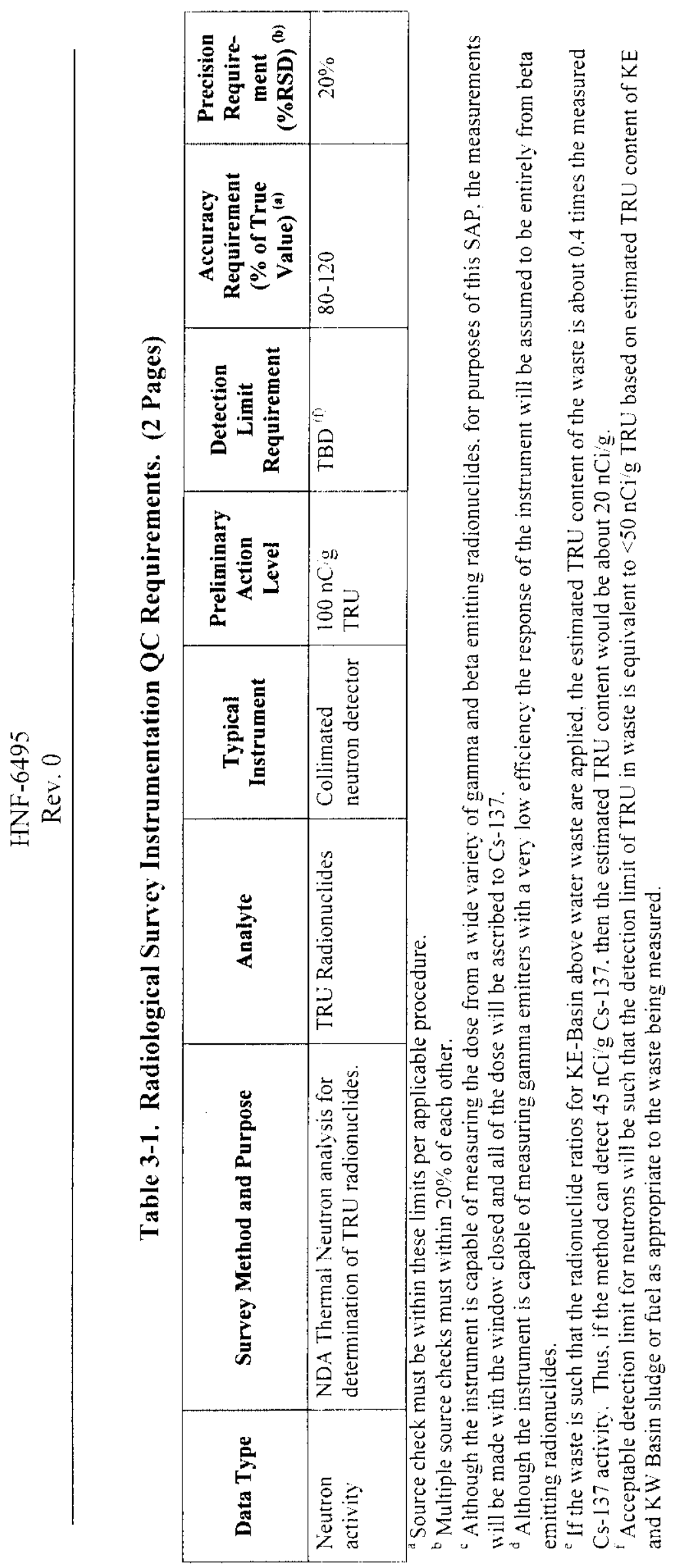




\subsection{HEALTH AND SAFETY}

All field operations required by this SAP will be conducted in accordance with the HASP (HNF 2000b).

The HASP identifies the primary hazards associated with debris management activities. Some of the hazards included direct radiation exposure, potential personnel contamination, potential inhalation of airborne concentrations of radioactive materials, and exposures to hazardous substances. Rather than list the requirements to mitigate and control radiological and hazardous chemical exposures, the HASP references documents which provide the necessary direction to mitigate and control these hazards. To assist in the development of sub-tier or task-/subprojectspecific implementation of the HASP, the Project Management Hanford Contract (PHMC) Automated Job Hazards Analysis (AJHA) will be used in accordance with HNF-PRO-079, "Job Hazard Analysis". The AJHA is a computer-based application to help planners identify the potential hazards associated with a job task, and to implement the proper controls based on the hazards identified. Proper use of the AJHA in conjunction with the project HASP (HNF 2000b), plus specifics associated with the task, will constitute acceptable sub-tier or task-/subprojectspecific implementation of the HASP. In accordance with 29 CFR 1910.120(6)(1)(v) (OSHA99A), the HASP (HNF 2000b) shall be made available to PHMC employees and any contractor/subcontractor involved with hazardous waste operations.

The PHMC has a robust and mature radiation protection program. This program is described in the HSRCM (DOE-RL 1996). The HSRCM fully implements 10 CFR 835, Occupational Radiation Protection, as currently amended. The planning of work involving radiation and radioactive materials hazards is further described in HNF-PRO-1623, "Radiological Work Planning Process." Implementation of radiological work and radiation protection activities is detailed in procedures. Procedures address roles and responsibilities, qualifications, training, implementation of the ALARA philosophy, external and internal dosimetry, monitoring and surveillance, work control mechanisms (e.g., radiation work permits, and access and entry requirements), self-assessments, and use of specific radiation monitoring devices and meters.

The PHMC Chemical Management Program (CMP), as described in HNF-PRO-2258 ("Chemical Management"), in conjunction with implementation of the PHMC AJHA in accordance with HNF-PRO-079, will be relied upon to protect the worker, general public, and the environment from specific chemical substances and their associated hazards. The CMP provides direction for the acquisition, storage, transportation, use, final disposition, record keeping, and management review of program performance for chemicals at the Hanford Site. 


\subsection{REFERENCES}

10 CFR 835, "Department of Energy Occupational Radiation Protection," Code of Federal Regulations, as amended.

29 CFR 1910.120, 1991, "Hazardous Waste Operations and Emergency Response," Code of Federal Regulations, as amended.

40 CFR 268.48, "Land Disposal Restrictions," Code of Federal Regulations, as amended.

ANSI, 1991, Calibration and Use of Germanium Spectrometers for the Measurement of GammaRay Emission Rates of Radionuclides, ANSI N42.14-1991, American National Standards Institute, New York.

BHI, 1998, Environmental Restoration Disposal Facility Waste Acceptance Criteria, BHI-00139, Rev. 3, Bechtel Hanford, Inc., Richland, Washington.

Comprehensive Environmental Response, Compensation, and Liability Act of 1980, 42 USC 9601 et seq.

DOE-RL, 1996, Hanford Site Radiological Control Manual, HSRCM-1, as amended, Prepared for the U.S. Department of Energy, Richland Operations Office by the Hanford Contractors, Richland, Washington.

DOE-RL, 1998, Hanford Analytical Services Quality Assurance Requirements Documents, DOE/RL-96-68, Rev. 2, U.S. Department of Energy, Richland Operations Office, Richland, Washington.

DOE-RL, 1999, 105 K-Basins 1998 Debris Report, DOE/RL-99-25, Rev. 0, U.S. Department of Energy, Richland Operations Office, Richland, Washington.

DOE-RL, 1999, Focused Feasibility Study for the K Basins Interim Remedial Action, DOE/RL-98-66, Rev. 4, U.S. Department of Energy, Richland Operations Office, Richland, Washington.

EPA, 1997, Test Methods for Evaluating Solid, Waste Physical/Chemical Methods, SW-846, 3rd Edition, as amended by Updates I (July, 1992), IIA (August, 1993), IIB (January, 1995), and III (1997), U.S. Environmental Protection Agency, Washington, D.C.

EPA, DOE, and Ecology, 1999, Declaration of the Record of Decision for DOE Hanford 100 Area, 100-KR-2 Operable Unit, U.S. Department of Energy, U.S. Environmental Protection Agency (EPA 541-R99-059), and Washington State Department of Ecology, Richland, Washington. 
HNF, 1997, 105-K Basin Material Design Basis Feed Description for Spent Nuclear Fuel Project Facilities, HNF-SD-SNF-TI-009, Rev. 1, Fluor Hanford, Inc., Richland, Washington.

HNF, 2000a, Data Quality Objectives Process for Designation of K-Basin Debris, HNF-6273, Rev. 0, Fluor Hanford, Inc., Richland, Washington.

HNF, 2000b, K Basins Interim Remedial Action Health and Safety Plan, HNF-4747, Rev. 1, Spent Nuclear Fuel Project, Richland, Washington.

HNF, 2000c, 105-K Basin Material Design Basis Feed Description for Spent Nuclear Fuel Project Facilities, HNF-SD-SNF-TI-009, Rev. 3,Volume 1, "Fuel," Fluor Hanford Company, Richland, Washington.

HNF, 2000d, 105-K Basin Material Design Basis Feed Description for Spent Nuclear Fuel Project Facilities, HNF-SD-SNF-TI-009, Rev. 3,Volume 2, "Sludge," Fluor Hanford Company, Richland, Washington.

Jochen, R.M., 2000, Letter of Instruction: CACN No. 111456, Spent Nuclear Fuel Facility Operations K Basins Routine Water Samples, From R. M. Jochen to L. L. Lockrem, dated February 28, 2000, Spent Nuclear Fuel Project, Richland, Washington.

Markel, L.P., 2000, 222-S Laboratory QA Plan, HNF-SD-CP-QAPP-016, Rev. 4, Fluor Hanford, Richland, Washington.

NRC, 1991, Passive nondestructive assay of nuclear materials, NUREG/CR-5550, LA-UR-90732, U.S. Nuclear Regulatory Commission, Washington, D.C.

Resource Conservation and Recovery Act of 1976, 42 U.S.C 6901 et seq.

SNF-OPS-DI-005, "IXM Curie Loading Calculations," Procedure in Progress.

SNF-OPS-DI-005, "Perform Dose to Curie Calculations," Procedure in Progress.

Toxic Substances Control Act of 1976, 15 U.S.C., et seq.

WAC-173-303, Dangerous Waste Criteria, Washington Administrative Code, as amended.

WHC, 1990, Characterization of Radioactive Waste at 100 Area, WHC-SD-NR-RPT-005, Rev. 0, Westinghouse Hanford Company, Richland, Washington.

WHC, 1996a, Basis for Dose Rate to Curie Assay Method, WHC-SD-WM-RPT-267, Rev. 0, Westinghouse Hanford Company, Richland, Washington. 
WHC, 1996b, Procedure for Categorizing and Inventorying Waste in Standard Containers, WHC-SD-WM-PROC-020, Rev. 0, Westinghouse Hanford Company, Richland, Washington.

WHC, 1996c, Characterization of Empty Fuel Storage Canisters in 105 KE Basin, WHC-SDSNF-TI-019, Rev. 0, Westinghouse Hanford Company, Richland, Washington.

WHC, 1996d, “Analytical Report for K Basin Pipe - FT6021", 75745-FAST-96-050, Internal Memo from L. L. Lockrem to R. M. Jochen, dated June 5, 1996, Westinghouse Hanford Company, Richland, Washington.

WHC, 1996e, Listed Waste History at Hanford Facility TSD Units, WHC-MR-0517, Rev. 0, Westinghouse Hanford Company, Richland, Washington.

WHC, 1996f, 105KE Basin PCB Wipe Sampling and Analysis, WHC-SD-SNF-EV-001, Rev. 0, ECN 189420, Westinghouse Hanford Company, Richland, Washington.

WHC, 1996g, Procedure for Categorizing and Inventorying Waste in Standard Containers, WHC-SD-WM-PROC-020, Rev. 0, Westinghouse Hanford Company, Richland, Washington.

WHC, 1997, Characterization Plan for Spent KE Basin Ion Exchange Modules, WHC-SD-SNFTI-039, Rev. 1, Westinghouse Hanford Company, Richland, Washington.

\subsection{SPENT NUCLEAR FUELS PROCEDURES}

AD-14-004, "Radiological Area Access Control."

MS-1-036-02, “Management Assessments," Effective Date: July 8, 1999, Spent Nuclear Fuel Project Administrative Procedure.

OP-02-025, "Basin Water Quality Control," Spent Nuclear Fuels Operations Project Technical Procedure.

OP-43-005E, "Collect Routine Water Samples at 105-KE," Rev. 3D, Issue Date: October 1, 1996, Spent Nuclear Fuels Operations Project Technical Procedure.

OP-43-006W, "Collect Routine Water Samples at 105-KW," Rev. 4C, Issue Date: February 18, 1999, Spent Nuclear Fuels Operations Project Technical Procedure.

OP-43-028, "Collect Monthly Center of Basin Water Samples," Rev. 0D, Issue Date:

December 9, 1996, Spent Nuclear Fuels Operations Project Technical Procedure.

OP-43-030, "Transport Water Samples to 222-S Lab," Rev. 0B, Issue Date: December 9, 1996, Spent Nuclear Fuels Operations Project Technical Procedure. 
OP-46-006, "Processing Contaminated Waste for ERDF Disposal," Rev. 0/A, Issue Date: December 13, 1999, Spent Nuclear Fuels Operations Project Technical Procedure.

QA-11-006-02, "Quality Assurance Surveillances," Effective Date: October 4, 1999, Spent Nuclear Fuel Project Administrative Procedure.

TN 8-001-08, "General Training Administration," Spent Nuclear Fuel Project Administrative Procedure, Effective Date: February 11, 2000.

\subsection{PROJECT HANFORD MANAGEMENT SYSTEM PROCEDURES}

HNF-PRO-052, "Corrective Action Management," Rev. 4, Effective Date: April 15, 2000.

HNF-PRO-079, “Job Hazard Analysis,” Rev. 5, Effective Date: May 5, 2000.

HNF-PRO-156, "Non-radioactive Hazardous Materials/Hazardous Waste (HM/HW) Shipments," Rev. 1, Effective Date: April 15, 2000.

HNF-PRO-157, "Radioactive Material/Waste Shipments," Rev. 1, Effective Date: April 15, 2000.

HNF-PRO-338, "Asbestos Control—Construction Industry," Rev. 1, Effective Date: May 23, 2000.

HNF-PRO-408, "Asbestos-Facility Management/General Industry," Rev. 1, Effective Date: May 18, 2000.

HNF-PRO-436, "Radiation Protection Instrument Program," Rev. 1, Effective Date: April 15, 2000.

HNF-PRO-632, "GM Portable Survey Instrument," Rev. 1, Effective Date: March 29, 2000.

HNF-PRO-633, Rev. 1, "Portable Alpha Meter," Effective Date: April 3, 2000.

HNF-PRO-648, Rev. 2, “Eberline RO-3B (CP),” Effective Date: March 30, 2000.

HNF-PRO-1623, Rev. 2, "Radiological Work Planning Process," Effective Date: April 15, 2000.

HNF-PRO-1892, Rev. 2, "Documentation of Radiological Surveys," Effective Date: April 15, 2000.

HNF-PRO-2258, Rev. 0, "Chemical Management," Effective Date August 31, 1998. 


\subsection{WASTE MANAGEMENT LABORATORY ANALYTICAL PROCEDURES}

LA-220-103, Rev. F-7, "90Strontium in Leachates of Soil, Vegetation, Air Filters and Other Solid Samples,” Release Date: November 8, 1999.

LA-220-104, Rev. E-7, "90Strontium in Water by Carbonate Precipitation," Release Date: November 8, 1999.

LA-506-101, Rev. A-3, "Determination of Trace Elements and Radionuclides by Inductively Coupled Plasma-Mass Spectrometry using TJA Poems," Release Date: November 10, 1999.

LA-548-121, Rev. F-2, "Preparation of Sample Mounts for Gamma Energy Analysis," Release Date: November 15, 1999.

LA-953-104, Rev. B-3, "Determination of Plutonium and Americium by Extraction with TRU•SPEC Resin," Release Date: December 21, 1999. 


\section{APPENDIX A}

INFORMATION SUPPORTING DEVELOPMENT OF RADIONUCLIDE RATIOS FOR CHARACTERIZATION OF K BASIN DEBRIS AND IXMs 
The source-term for all of the radionuclides that could reasonably be expected in the K Basin is from $\mathrm{N}$ Reactor fuel and associated activation products. The selection of constituents of concern (COCs) was discussed in Appendix B of the Data Quality Objectives Process for Designation of $K$-Basin Debris (HNF 2000a). The selection was performed by listing all of the radionuclides that have been reported as present in the fuel or measured during historical characterization of the K East (KE), K West (KW), N, or 105-C fuel storage basins. Several selection criteria were applied to define the Environmental Restoration Disposal Facility (ERDF) Waste Acceptance Criteria (WAC) (BHI 1998) that all "Radioactive waste constituents shall be adequately characterized to permit proper segregation, treatment, storage, and/or disposal. This characterization shall ensure that the major radionuclide content of the waste is known and recorded during the waste management process,....."(ERDF WAC, Section 3.2.1.1). As a result of that effort, 20 radionuclide COCs were selected. The sections below discuss the application of radionuclide ratios to estimate the radionuclide content of $\mathrm{K}$ Basin debris for those radionuclides that are not measured from radionuclides that are measured.

\section{A.1 RADIONUCLIDE RATIOS FOR CHARACTERIZATION OF K BASIN DEBRIS}

Subsequent to the DQO report (HNF 2000a), an additional two-volume document was obtained. These documents were entitled:

1. HNF-SD-SNF-TI-009, Rev 3, 105-K Basin Material Design Basins Feed Description for Spent Nuclear Fuel Project Facilities, Volume 1, "Fuel" (HNF 2000b) and

2. HNF-SD-SNF-TI-009, Rev 3, 105-K Basin Material Design Basins Feed Description for Spent Nuclear Fuel Project Facilities, Volume 1, "Sludge" (HNF 2000c).

These two documents formed the basis for the selection of radionuclide ratios for the purpose of estimating the radionuclide content of above and below water waste from the $\mathrm{K}$ Basin. A WHC report (WHC 1990) contained extensive analyses of samples from the KE and KW Basin areas above the water line. These data provided valuable estimates of several radionuclides that had not been estimated from other sources (e.g., nickel-59, chromium-51, and manganese-54). In order to put all of the radionuclides from the various sources on a normalized basis, all final estimates of radionuclide content of the fuel (HNF 2000b, HNF 2000c) or samples from KW and KE Basins, were converted to a percent of the estimated cesium-137 concentration. For instance, if the reference indicated that the fuel would contain $500 \mathrm{Ci}$ of strontium-90 and $1,000 \mathrm{Ci}$ of cesium-137, the percentage entered into Table A-1 would be $50 \%$. 
In addition to the reports mentioned above there were several sampling efforts that had been conducted on various waste streams. The data from these various sampling efforts was tabulated and reviewed and ratios of each radionuclide measured were tabulated in Table A-1. Based on a review of the data from the various sources and the conceptual model for the waste stream it was determined that the following logic would be used to select the applicable ratio for each waste stream. Each basin, $\mathrm{KW}$ and $\mathrm{KE}$ could have three sets of ratios that could be applied to the waste depending on the origin of the waste. These three sets of ratios would be;

1. Ratios applicable to metallic waste that originated from below the water line of the basin and was washed before removing it from the water. The ratios used on this waste would be primarily fuel ratios (HNF 2000b) based on the data available and the conceptual model of how contamination occurred. Nondestructive assay (NDA) and laboratory results were also considered for this waste. Examples of this waste include fuel canisters, basin pipe racks, and any other pressure washed metal.

2. Ratios applicable to non-metallic or non-washed waste that originated from below the water line or the basin. The ratios used for this waste would be primarily those observed from measurement of basin floor sediments (HNF 2000c).

3. Ratios applicable to waste that originates from above the water line of the basin. The ratios used for this waste are primarily an amalgamation of data from WHC (1990) and data from recent air sampling data (Slotemaker 1999).

Additional discussion regarding the selection of applicable radionuclide ratios is provided below.

\section{A.1.1 Below-Water Waste}

The data reviewed and shown in Table A-1 indicated that washed metal items (e.g. pipe hangers and fuel canisters) more closely demonstrated the radionuclide ratios estimated for fuel (HNF $2000 \mathrm{~b}$ ) than for sludge (HNF 2000c). If ratios of specific radionuclides to cesium-137 were available on samples applicable to a specific waste stream, the data were used. If no data were available, then fuel ratios calculated from fuel (HNF 2000b) were be used as appropriate.

For non-metal items or non-washed metal items, professional judgement determined that the most appropriate source term was basin floor sludge (HNF 2000c). If there were no sludge ratios available from either sample data or published sources, then fuel ratios were selected as default. In Table A-1 the available ratios that were deemed appropriate are tabulated along with a column that provides the chosen ratios for application to the $\mathrm{K}$ Basin debris.

For KW there was no sludge data available on the basin floor sludge. Spent nuclear fuel (SNF) management has determined (HNF 2000c, Appendix D) that the KE Basin floor sludge data sufficiently bounds the KW Basin floor sludge data. While this is undoubtedly correct as far as safety and processing concerns, it was not deemed appropriate for waste characterization for this project. The KW Basin sludge is thought to be made up primarily of dirt and debris from sources other than the corrosion of fuel. The basin floor sludge from $\mathrm{KE}$ is enriched in 
transuranic (TRU) radionuclides due contact of the stored fuel directly with the basin water, removal of soluble radionuclides such as cesium-137 and precipitation of the TRUs. Thus, using $\mathrm{KE}$ Basin sludge radionuclide ratios on items in $\mathrm{KW}$ that have only contacted the $\mathrm{KW}$ Basin floor sludge would likely cause a significant overestimation of TRU radionuclides. As a result of these considerations, $\mathrm{KW}$ fuel ratios (HNF 2000b) will be used to estimate contamination of all below water waste removed from $\mathrm{KW}$. Table A-2 provides a summary of the final selected ratios.

\section{A.1.2 Above-Water Waste}

Significant differences from radionuclide ratios found in fuel and found in $\mathrm{KE}$ versus $\mathrm{KW}$ were noted in historical analyses of samples from above water portions of the KE and KW (WHC 1990). Another source of data that was used was the air sampling data from 1998 (Slotemaker 1999). It was reasoned that the data obtained from collecting high volume air samples would provide a reasonable estimate of the radionuclide mix that might be encountered from continued operations around the fuel basins. In selecting the final ratios to use, the highest ratio from either the WHC (1990) report or the air data were used if available for a specific radionuclide. Not all of the $\mathrm{COC}$ radionuclides were measured on the samples from either source. If there were no measured ratios, then $\mathrm{KW}$ fuel data radionuclide ratios (HNF 2000b) were selected. Table A-2 provides a summary of the final selected radionuclide ratios.

\section{A.1.3 Estimate of Gamma Survey Ratios to Define Anomalous Waste}

The purpose of estimating a ratio of all COC gamma emitters to cesium-137 is to allow the use of a hand-held portable gamma detector to survey waste as it is coming out of the basin and being bagged or boxed. The survey will alert project staff to the presence of waste that is outside of the anticipated ratios that were discussed above. It is assumed that if the measured contamination levels (dpm per package) of the six major anticipated gamma emitters (including cesium-137) to the measured cesium-137 activity (dpm/package) is within a certain range, then the waste is presumed to contain contamination that can be adequately estimated using the listed ratios in Table A-2. If the gamma survey ratio is outside of the estimated range, then the waste is considered anomalous and will be subjected to additional NDA measurements and/or sampling.

In Table A-2, the calculated gamma ratio is provided at the bottom of each set of ratios. Also tabulated is a target ratio. The measured ratios cannot fall below $100 \%$ unless there is an instrument malfunction. If the measured ratio for one of the waste streams that has a lower bound greater than $100 \%$ (columns 3 and 7) falls below the target ratio indicated, then the project may elect to use one of the other sets of ratios that is more conservative and consistent with the measured gamma ratio and waste. If the ratio falls above the target range (columns 4, 5, 6, and 7), then the project may elect to use the ratios in column 3 . If the measured gamma ratio of the waste is greater than the highest target ratio (Table A-2, $125 \%$ for $\mathrm{KE}$ ), the waste will be set aside and contingency NDA and/or sampling performed to establish the appropriate set of radionuclide ratios to apply to the waste. 
It should be noted that the gamma spectrum-measuring instrument that is used must be calibrated against cesium-137, Cobalt-60, europium-152, europium-154, europium-155 and antimony-125. Ratios of expected cpm in the cesium-137 portion of the spectra compared to broader portion of the gamma spectrum that includes all of the calibrated radionuclides would be estimated based on the calibration data and would replace those in Table A-2, which are based on dpm. 


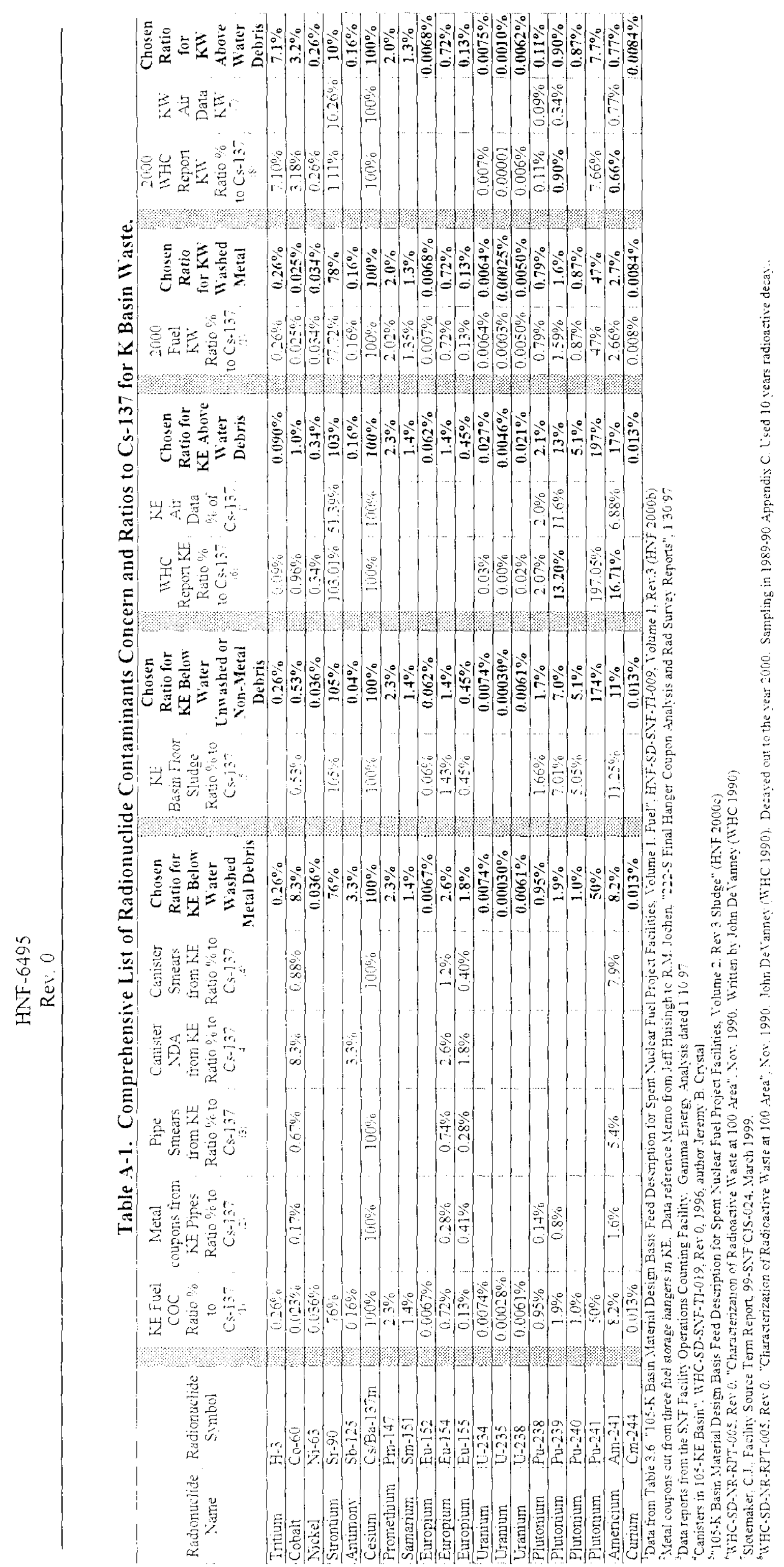


Table A-2. Summary List of Radionuclide Contaminants Concern and Ratios to Cs-137 for K Basin Waste.

\begin{tabular}{|c|c|c|c|c|c|c|}
\hline $\mathrm{Radlomuclide}$ & $\begin{array}{l}\text { Radionuclide } \\
\text { Symbol }\end{array}$ & $\begin{array}{l}\text { Chosen Ratio for } \\
\text { Ka Below Water } \\
\text { Washed Metal } \\
\text { Bebris }\end{array}$ & $\begin{array}{l}\text { Chosen Ratio for } \\
\text { KE Below Water } \\
\text { Uawashed or } \\
\text { Non-Metal } \\
\text { Debris }\end{array}$ & $\begin{array}{l}\text { Chosen Ratio } \\
\text { for Ke } \\
\text { Above Water } \\
\text { Debris }\end{array}$ & $\begin{array}{l}\text { Chosen Ratio } \\
\text { tor KW Wushed }\end{array}$ & $\begin{array}{l}\text { Chosen Ratio } \\
\text { for KW Abore } \\
\text { Water Debris }\end{array}$ \\
\hline Column 1 & Column 2 & Column 3 & Column 4 & Column 5 & Column 6 & Column ? \\
\hline Tritium & $\mathrm{H}-3$ & $0.26 \%$ & $0.26 \%$ & $0.090 \%$ & $0.26 \%$ & $7.1 \%$ \\
\hline Cobalt & $\mathrm{Co}-60$ & $8.3 \%$ & $0.53 \%$ & $1.0 \%$ & $0.025 \%$ & $3.2 \%$ \\
\hline Nickel & $\mathrm{Ni}-63$ & $0.036 \%$ & $0.036 \%$ & $0.34 \%$ & $0.034 \%$ & $0.26 \%$ \\
\hline Strontium & $\mathrm{Sr}-90$ & $76 \%$ & $105 \%$ & $103 \%$ & $78 \%$ & $10 \%$ \\
\hline Antimony & $\mathrm{Sb}-125$ & $3.3 \%$ & $0.04 \%$ & $0.16 \%$ & $0.16 \%$ & $0.16 \%$ \\
\hline Cesium & $\mathrm{Cs} / \mathrm{Ba}-137 \mathrm{~m}$ & $100 \%$ & $100 \%$ & $100 \%$ & $100 \%$ & $100 \%$ \\
\hline Promethium & Pm-147 & $2.3 \%$ & $2.3 \%$ & $2.3 \%$ & $2.0 \%$ & $2.0 \%$ \\
\hline Samarium & $\mathrm{Sm}-151$ & $1.4 \%$ & $1.4 \%$ & $1.4 \%$ & $1.3 \%$ & $1.3 \%$ \\
\hline Europium & Eu- 152 & $0.0067 \%$ & $0.062 \%$ & $0.062 \%$ & $0.0068 \%$ & $0.0068 \%$ \\
\hline Europium & Eu-154 & $2.6 \%$ & $1.4 \%$ & $1.4 \%$ & $0.72 \%$ & $0.72 \%$ \\
\hline Europium & Eu-155 & $1.8 \%$ & $0.45 \%$ & $0.45 \%$ & $0.13 \%$ & $0.13 \%$ \\
\hline Uranium & $\mathrm{U}-234$ & $0.0074 \%$ & $0.0074 \%$ & $0.027 \%$ & $0.0064 \%$ & $0.0075 \%$ \\
\hline Uranium & $\mathrm{U}-235$ & $0.00030 \%$ & $0.00030 \%$ & $0.0046 \%$ & $0.00025 \%$ & $0.0010 \%$ \\
\hline Uranium & U-238 & $0.0061 \%$ & $0.0061 \%$ & $0.021 \%$ & $0.0050 \%$ & $0.0062 \%$ \\
\hline Plutonium & $\mathrm{Pu}-238$ & $0.95 \%$ & $1.7 \%$ & $2.1 \%$ & $0.79 \%$ & $0.11 \%$ \\
\hline Plutonium & $\mathrm{Pu}-239$ & $1.9 \%$ & $7.0 \%$ & $13 \%$ & $1.6 \%$ & $0.90 \%$ \\
\hline Plutonium & $\mathrm{Pu}-240$ & $1.0 \%$ & $5.1 \%$ & $5.1 \%$ & $0.87 \%$ & $0.87 \%$ \\
\hline Plutonium & $\mathrm{Pu}-241$ & $50 \%$ & $174 \%$ & $197 \%$ & $47 \%$ & $7.7 \%$ \\
\hline Americium & Am-241 & $8.2 \%$ & $11 \%$ & $17 \%$ & $2.7 \%$ & $0.77 \%$ \\
\hline Curium & $\mathrm{Cm}-244$ & $0.013 \%$ & $0.013 \%$ & $0.013 \%$ & $0.0084 \%$ & $0.0084 \%$ \\
\hline \multicolumn{2}{|c|}{ Estimated Gamma Ratios } & $116 \%$ & $103 \%$ & $103 \%$ & $101 \%$ & $104 \%$ \\
\hline \multicolumn{2}{|c|}{ Target Gamma Ratio } & $105-125 \%$ & $100-110 \%$ & $100-110 \%$ & $100-105 \%$ & $105-110 \%$ \\
\hline
\end{tabular}




\section{A.2 RADIONUCLIDE RATIOS FOR CHARACTERIZATION OF K BASIN IXMs}

The current process for estimating the radionuclide content of ion-exchange modules (IXMs) that have been removed from service is generally described in the Characterization Plan for Spent KE Basin Ion Exchange Modules (HNF-SD-SNF-TI-039) (WHC 1997). The characterization methodology described in that document uses cesium-137 and total alpha to calculate by ratio, the inventory of all reportable radionuclides in the IXM. Radionuclide ratios for radionuclides measured were obtained from previous process data and were supplemented by radionuclide ratios for radionuclides that were not measured from WHC-EP-0063-4, Appendix K (WHC 1996). The end result was an approach that estimated the radionuclide loading of the IXMs solely from gross alpha and cesium-137 data. The current approach, as implemented on a controlled spreadsheet through instruction SNF-OPS-DI-004, entitled "IXM Curie Loading Calculations" has been modified from the initial characterization plan. The current desk instruction uses monthly center of basin data containing additional analytical results from several more of the COCs (uranium, plutonium-239/240, plutonium-238, strontium-90, tritium, and americium-241).

A recent revision of the Hanford Site waste acceptance document (HNF-EP-0063, Rev. 5, [HNF 1998]) has deleted the Appendix K tables that were still used. In addition, as discussed in the sections above, a new documents that describe the specific fuel source terms in the K Basin in detail has become available (HNF 2000b). The data used to establish new ratios include the new fuel source term data (HNF 2000b) and 12 routine monthly center-of-basin samples that were collected in KE and KW January 1999 to December 1999.

Table A-3 lists the K Basin fuels data for both $\mathrm{KE}$ and $\mathrm{KW}$ as well as the average of the 12 monthly center of basin samples. Also listed for comparison is the Table K-1 (WHC 1996) values currently used. All of the data has been converted to \% of the estimated cesim-137 activity for ease of comparison.

In general application, the results of all of the radionuclides that are measured will be used directly. Those that are not measured will be estimated by applying the ratios in Table A-3 to those radionuclides that are measured. In the case of plutonium-239/240, the isotopic mix for plutonium isotopes that is provided in the fuel (HNF 2000b) is applied to the measured plutonium-239/240 in order to estimate individual plutonium isotopes. The plutonium-238 isotope measured is often very low and, thus, if the data are censored and the detection limit data are used, the estimate will be a significant overestimate of plutonium- 238 in the water. If plutonium-238 levels in the water are below detection limits, then the plutonium-239/240 data and predicted isotopic ratios from fuel are used to predict the plutonium-238 concentrations in the water. Similarly, the uranium concentrations for each COC isotope are estimated from the total uranium activity multiplied by the appropriate specific activity for each of the uranium isotopes. Curium is estimated by assuming that the ratio $\%$ in the water is the same as in the fuel. 
Tritium is not concentrated by the ion exchange resin and is not currently reported as a waste constituent in the IXMs. However since tritium is a COC identified in this Sampling and Analysis Plan (SAP) and data are available from the analytical results of the monthly center of basin samples, it will be reported in IXMs characterized under this SAP. Recent calculations (Appendix B) have estimated the maximum amount of water that is likely to be held up in the IXM after it is drained and sealed. These calculations will be used to establish a direct calculation that relates the measured or estimated concentration of tritium to the total amount of tritium that is held up in the IXM. The calculations in Appendix B that estimate the maximum amount of water in the IXM will be used to establish that factor.

The approach applied through this SAP will employ the same general radiochemical analysis and spreadsheet currently used and utilizes the radionuclide measurements that are performed on the basin water during the operational life of the IXM. Ratios that have been measured on monthly basin water samples in 1999 by the 222-S Laboratory are shown for comparison and for use if analytical data are not available for specific radionuclides. The estimate of radionuclide content for the IXMs may be based on the radionuclide concentration that are measured in the center of basin samples or a or a net (inlet-outlet) water concentration. The estimated concentration in the water is combined with the total measured flow of basin water through the IXM. The calculation that is currently used has locations to enter the flow rate, time of service and subsequently calculate the estimated total curies of radionuclide using the IXM flow rate data and analytical results (sheet 1 in the current spreadsheet). The current calculation worksheet labeled "IXM Calcs." provides the applicable ratios to estimate radionuclides other than those measured. The current calculation will be placed into instruction SNF-OPS-DI-004 to include the COCs ratios that are listed in Table A-3 and to include a calculation for the tritium content of the IXM.

The major changes for IXMs characterized under this SAP are that gross alpha measurements are not used to estimate radionuclide content of the IXM, tritium will be reported, and new radionuclide ratios will be used for those radionuclides not measured based on revised fuel source terms and historical water data.

\section{A.3 REFERENCES}

SNF-OPS-DI-004, "IXM Curie Loading Calculations," 2000.

BHI, 1998, Environmental Restoration Disposal Facility Waste Acceptance Criteria, BHI-00139, Rev. 3, Bechtel Hanford, Inc., Richland, Washington.

HNF, 1998, Hanford Site Solid Waste Acceptance Criteria, HNF-EP-0063-4, Rev. 5, Fluor Hanford, Richland, Washington.

HNF, 2000a, Data Quality Objectives Process for Designation of K-Basin Debris, HNF-6273, Rev. 0, Fluor Hanford, Inc., Richland, Washington. 
HNF, 2000b, 105-K Basin Material Design Basis Feed Description for Spent Nuclear Fuel Project Facilities, HNF-SD-SNF-TI-009, Rev. 3,Volume 1, "Fuel," Fluor Hanford Company, Richland, Washington.

HNF, 2000c, 105-K Basin Material Design Basis Feed Description for Spent Nuclear Fuel Project Facilities, HNF-SD-SNF-TI-009, Rev. 3,Volume 2, "Sludge," Fluor Hanford Company, Richland, Washington.

Huisingh, J., 1997, "222-S Final Hanger Coupon Analysis and Rad Survey Reports", Don't Say It... Write It!, dated January 30, 1997.

Slotemaker, 1999, "Facility Source Term Report," 99-SNF/CJS-024, Interoffice Correspondence from P.G. Huntley to C. J. Slotemaker, dated March 29, 1999.

WHC, 1990, Characterization of Radioactive Waste at 100 Area, WHC-SD-NR-RPT-005, Rev. 0, Westinghouse Hanford Company, Richland, Washington.

WHC, 1996, Hanford Site Solid Waste Acceptance Criteria, WHC-EP-0063-4, Rev. 4, Westinghouse Hanford Company, Richland, Washington.

WHC, 1997, Characterization Plan for Spent KE Basin Ion Exchange Modules, HNF-SD-SNFTI-039, Rev. 1, Westinghouse Hanford Company, Richland, Washington. 


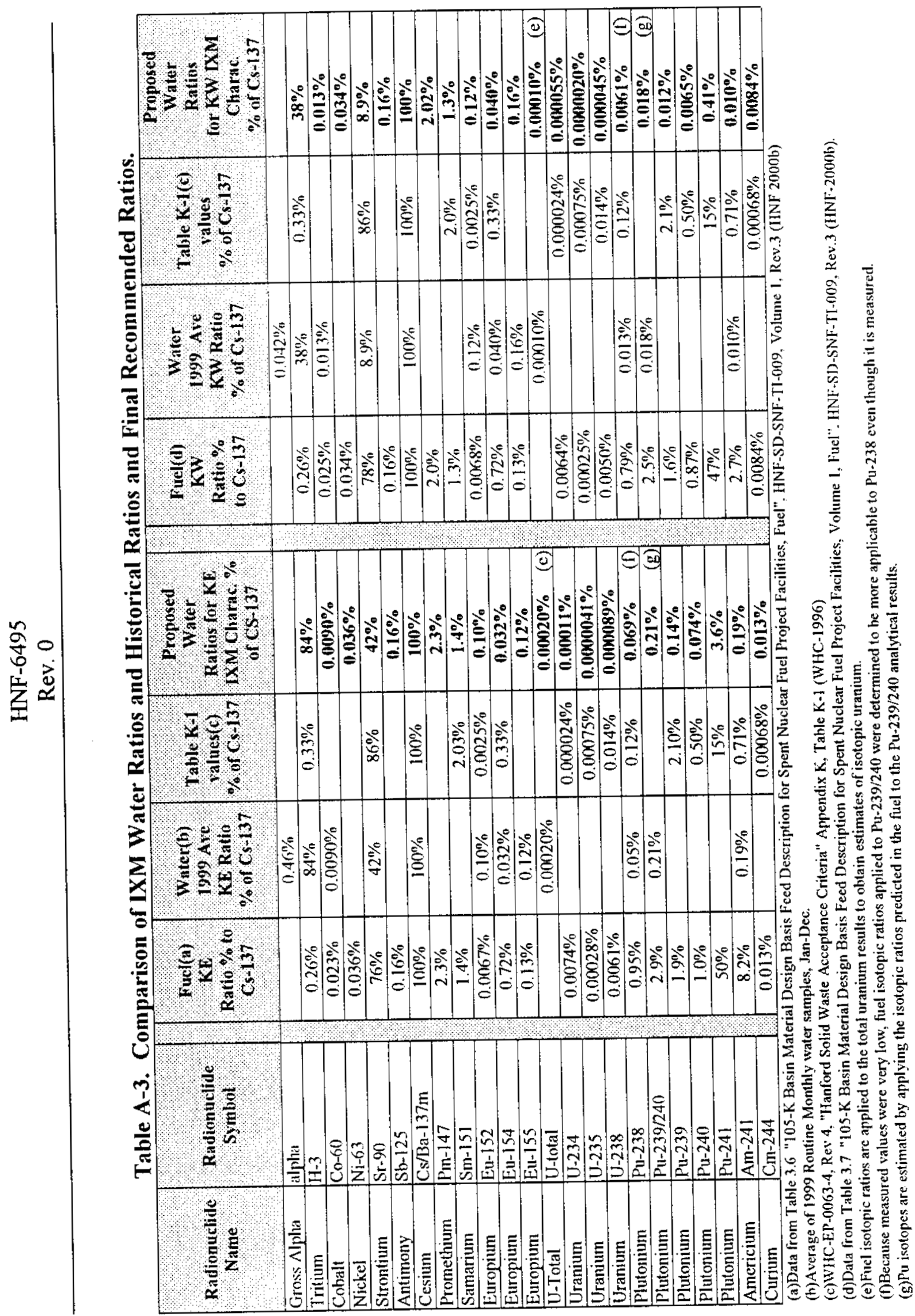

$\frac{1}{4}$ 
HNF-6495

Rev. 0

\section{APPENDIX B}

\section{ESTIMATED TRITIUM CONTENT IN SPENT 100K IXMS}

B-1 
The calculations below provide a basis for estimating the water content of the drained IXMs. The example shown below estimates the maximum tritium content of an IXM from the maximum tritium content measured in $\mathrm{KE}$ Basin water over the time period indicated. The calculation is shown to demonstrate the likely upper bound of tritium in an IXM. For purposes of waste characterization under this SAP, the estimate of $501.8 \mathrm{~kg}$ of water in the resin and 24.3 $\mathrm{kg}$ of water in the bottom of the IXM will be used in conjunction with the measured tritium concentration in the basin water over the life of the IXM to obtain an accurate accounting of the H-3 in an IXM. As discussed in Appendix A, Section A.2, this calculation will be integrated into the current spreadsheet use to estimate radionuclide content of the total IXM package.

These estimates of water in the IXM package will be valid unless there is a configuration change or a change in the type of resin that is in the IXM.

Assumptions:

1. IXM Mixed Bed(MB) Volume $=6$ vessels $/$ IXM X $3.5 \mathrm{ft}^{3} / \mathrm{vessel}=30 \mathrm{ft}^{3}$

2. $100 \mathrm{KE}$ basin uses Purolite MB resin NRW-35 which consists of $60 \%$ by volume (A-600) anion and $40 \%$ resin by volume cation resin.

3. The $\mathbf{8 0} \%$ moisture content is higher than Purolite $\mathrm{mfg}$. Literature indicated.

4. The maximum tritium conc. used is from $100 \mathrm{KE}$ basin which is typically two orders of magnitude higher than for $100 \mathrm{KW}$ basin.

$46 \mathrm{lbs} . / \mathrm{ft}^{3} \times 30 \mathrm{ft}^{3}=1,380 \mathrm{lbs} .(627.3 \mathrm{~kg})$

$80 \%$ (moisture content of resin beads) $X 627.3 \mathrm{~kg}=501.8 \mathrm{~kg}$ of water

3.44E-3 uCi/gm (maximum basin water tritium conc. '95-'99) $\mathrm{X} 5.02 \mathrm{E}+5 \mathrm{gm}=1.73 \mathrm{E}+3$ $\mathrm{uCi}$ or $1.73 \mathrm{E}-3 \mathrm{Ci}$

5. Total volume of IXM including the concrete $=7.83 \mathrm{M}^{3}$

2.21E-4 Ci/ $\mathrm{M}^{3}$ (tritium conc. In moisture trapped in $\mathrm{MB}$ resin beads including the concrete volume)

The volume of water remaining in the bottom of each vessel was previously estimated to be $246 \mathrm{in}^{3} /$ vessel X $6=1,480 \mathrm{in}^{3}$ or $2.43 \mathrm{E}+1$ Liters

$3.44 \mathrm{E}+0 \mathrm{uCi} / \mathrm{L}$ (maximum basin water tritium conc. '95-'99) $\mathrm{X} 2.43 \mathrm{E}+1$ Liters $=$ $8.36 \mathrm{E}+1 \mathrm{uCi}$ or $8.36 \mathrm{E}-5 \mathrm{Ci}$ 
Therefore,

1.81E-3 Ci $=$ Total Estimated tritium in a spent IXM (includes water in the resin plus water remaining in bottom of vessel)

Calculation done by: Bill Klover

Reviewed by: Rod Jochen
Date: $03 / 06 / 00$

Date: $03 / 06 / 00$ 


\section{DISTRIBUTION SHEET}

To

C. D. Lucas

Project Title/Work Order

Sampling and Analysis Plan for $K$ Basins Debris

From
J. L. Westcott

R. B. Wilkinson

J. L. Westcott

O. M. Holgado

C. A. Rodriguez

R. R. Connoliy

J. R. James

M. A. Casbon

W. S. Thompson

R. W. Jackson

J. M. Atwood

B. D. Shilperoort

C. D. Lucas

D. J. Watson

P. T. Day

J. H. Wicks

J. H. Zimmerman

N. o. Hinojosa

G. C. Triner

\section{Name}

Page 1 of 1

Date June 14, 2000

EDT No. 622851

ECN No.

\begin{tabular}{|c|c|c|c|c|}
\hline MSIN & $\begin{array}{c}\text { Text } \\
\text { With All } \\
\text { Attach. }\end{array}$ & Text Only & $\begin{array}{l}\text { Attach.I } \\
\text { Appendix } \\
\text { Only }\end{array}$ & $\begin{array}{c}\text { EDT/ECN } \\
\text { Only }\end{array}$ \\
\hline R3-11 & & & & $x$ \\
\hline$T 4-05$ & $x$ & & & \\
\hline R3-81 & $\mathrm{x}$ & & & \\
\hline R3-81 & $\mathrm{x}$ & & & \\
\hline $\mathrm{T} 3-04$ & & & & $x$ \\
\hline L6-06 & & & & $\mathrm{x}$ \\
\hline $\mathrm{T} 2-05$ & & & & $\mathrm{x}$ \\
\hline $\mathrm{H} 9-03$ & $x$ & & & \\
\hline$x 5-54$ & $x$ & & & \\
\hline HO-02 & & & & $x$ \\
\hline $\mathrm{T} 2-04$ & $x$ & & & \\
\hline$\times 3-74$ & & & & $\mathrm{x}$ \\
\hline$\times 3-79$ & $x$ & & & \\
\hline R3-11 & $\mathrm{x}$ & & & \\
\hline$\times 3-71$ & & & & $x$ \\
\hline$\times 3-67$ & $x$ & & & \\
\hline$\times 3-67$ & $x$ & & & \\
\hline $\mathrm{T} 3-04$ & & & & $x$ \\
\hline & & & & \\
\hline & & & & \\
\hline & & & & \\
\hline & & & & \\
\hline & & & & \\
\hline & & & & \\
\hline & & & & \\
\hline & & & & \\
\hline & & & & \\
\hline & & & & \\
\hline & & & & \\
\hline & & & & \\
\hline & & & & \\
\hline & & & & \\
\hline
\end{tabular}

